\title{
Design, synthesis and biological evaluations of covalent inhibitors of Focal Adhesion Kinase (FAK) against human malignant glioblastoma
}

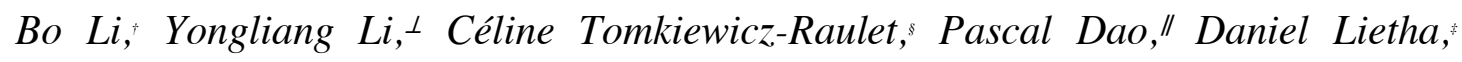
Expédite Yen-Pon, ${ }^{\star}$ Zhiyun Du,,$^{\perp}$ Xavier Coumoul, Christiane Garbay, Mélanie Etheve-Quelquejeu, Huixiong Chen"

$†$ Chemistry of RNA, nucleosides, peptides and heterocycles, CNRS UMR8601, Université de Paris, 45 rue des Saints-Pères, 75006 Paris, France

${ }^{\perp}$ School of Chemical Engineering and Light Industry, Guangdong University of Technology, no. 100 Waihuan Xi road, Education Mega Center, Guangzhou, 510006, China

'Toxicologie, Pharmacologie et Signalisation Cellulaire, INSERM, UMR S 1124, Université de Paris, 45 rue des Saints-Pères, 75006 Paris, France

"Université Côte d'Azur, CNRS, Institut de Chimie de Nice UMR7272, Nice, France

Cell Signalling and Adhesion Group, Structural and Chemical Biology, Biological Research Center (CIB), Spanish National Research Council (CSIC), Calle Ramiro de Maeztu, Madrid 28040, Spain 
ABSTRACT: Human malignant glioblastoma (GBM) is a highly invasive and lethal brain tumor. Targeting of integrin downstream signaling mediators in GBM such as focal adhesion kinase (FAK) seems reasonable and recently demonstrated promising results in early clinical studies. Herein we report the structure-guided development of a series of covalent inhibitors of FAK. These new compounds displayed highly potent inhibitory potency against $\mathrm{FAK}$ enzymatic activity with $\mathrm{IC}_{50}$ values in the nanomolar range. Several inhibitors retarded tumor cell growth as assessed by a cell viability assay in multiple human glioblastoma cell lines. They also significantly reduced the rate of U87 cell migration and delayed the cell cycle progression by stopping cells in the G2/M phase. Furthermore, these inhibitors showed a potent decrease of autophosphorylation of FAK in glioblastoma cells and its downstream effectors Akt and Erk as well as nuclear factor- $\kappa \mathrm{B}$. These data demonstrated that these inhibitors may have the potential to offer a promising new targeted therapy for human glioblastomas.

\section{- INTRODUCTION}

More than $30 \%$ primary brain tumor patients were diagnosed with gliomas and within these over 50\% are glioblastomas (GBMs), the most aggressive and malignant form of glioma in adults. GBM is characterized by poorly differentiated neoplastic astrocytes and a great invasiveness and infiltration of surrounding normal brain.2 The poor prognosis of patients with GBM has not been obviously improved over the last few decades. The difficulties in the treatment of these lethal cancers are their highly 
infiltrative feature, particularly resistant to conventional treatments and high recurrence rate. Extensive infiltration of the central nervous system by neoplastic cells in patients with GBM prevents complete and safe removal of the tumor through surgical resections..$^{3}$ The intrinsic apoptosis resistance of residual human malignant GBM cells and increased survival signaling hinder tumor elimination, resulting in the tumor recurrence. ${ }^{4}$ The resistance of GBM to conventional therapies is mainly due to a subpopulation of GBM stem cells (GSCs) ${ }^{s}$ and a highly mutated genome, which also results in significant tumor genetic heterogeneity and up-regulation of cellular signaling pathways involved in cell proliferation, angiogenesis, apoptosis, migration and invasion. ${ }^{6}$

Currently available treatment options for patients with GBM have limited efficacy. Despite the use of aggressive multimodal treatment strategies including maximum surgical resection, radiation and temozolomide chemotherapy, the median survival of patients with diagnosed GBM is generally less than 15 months.? Thus, new therapeutic approaches are of utmost importance. With an increased understanding of GBM biology and the complex networks of mechanisms involved in GBM tumors, current research efforts have mainly focused on innovative targeted therapies in order to accurately treat GBM with maximal efficacy and minimized side-effects. Among them, targeting of integrin downstream signaling mediators in GBM such as focal adhesion kinase (FAK) seems reasonable and demonstrated promising results in early clinical studies..$^{8.10}$ 
FAK, a non-receptor protein tyrosine kinase localized to focal adhesions, is uniquely positioned at the convergence point of integrins, which transmits signals from cell-surface receptors such as integrins, cytokines and growth factors and triggers subsequent signaling cascades leading to various functions in normal and cancer cells." Extensive research has elucidated that FAK signaling pathways can stimulate tumor progression and metastasis formation through their regulation of the epithelial mesenchymal transition (ECM), angiogenesis, cell migration and invasion. ${ }^{12-14}$ Other studies have shown the significant relationships between FAK and proliferation, survival and migration, as well as angiogenesis and grade of malignancy of gliomas in vitro and in vivo. ${ }^{15.17}$ In addition, FAK stimulates cancer stem cells (CSCs) renewal and promotes drug resistance through functioning in survival signaling pathways. ${ }^{18}$

Previous studies have indicated that targeting FAK expression with antisense oligonucleotide treatment may increase GBM cell sensitivity to chemotherapy. ${ }^{19}$ Therefore, several ATP-competitive inhibitors of FAK have been successfully developed and entered in preclinical and clinical trials (Figure 1), ${ }^{2021}$ and among them, TAE-226 showed a wide variety of effects on human GBM cells including inhibition of cell proliferation, migration and invasion as well as G0/G1 cell-cycle arrest.22 Moreover, TAE-226 treatment significantly prolonged the survival rate of nude mice in an intracranial glioblastoma xenograft model..$^{23}$ The therapeutic efficacy of TAE-226 may be a result of its ability to potently inhibit both tumor growth and tumor-associated angiogenesis. However, there is a poor correlation between 
enzymatic and cellular activity for the ATP-competitive inhibitors due to the cellular efficacy which can be considerably affected by the high physiological ATP concentration.<smiles>CNC(=O)c1ccccc1Nc1cc(Nc2ccc(N3CCOCC3)cc2OC)ncc1C(F)(F)F</smiles>

VS-4718<smiles>CNC(=O)c1ccccc1Nc1nc(Nc2ccc3c(c2OC)CCCCC3)ncc1Cl</smiles>

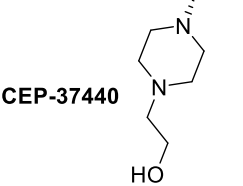<smiles>CONC(=O)c1ccccc1Nc1cc(Nc2cc(C)nn2C(C)C)ncc1Cl</smiles>

GSK-2256098<smiles>CN(Cc1cccnc1NCc1cccc2c1CC(=O)N2)c1cc(Nc2cccc(C(F)(F)F)c2)ncn1</smiles>

VS-6062<smiles>CNC(=O)c1ccccc1Nc1nc(Nc2cc(OC)c(Cl)cn2)ccc1N1CCOCC1</smiles>

TAE-226

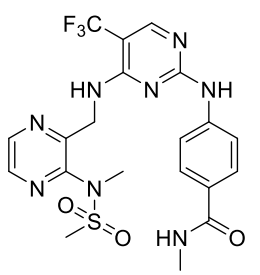

VS-6063

Figure 1. Structures of FAK inhibitors in preclinical and clinical trials

Covalent targeting of non-catalytic cysteine residues in dysregulated protein kinases is a powerful approach for enhancing pharmacological potency and selectivity and provide distinct advantages over conventional ATP-competitive inhibition. ${ }^{24}$ Covalent inhibitors behave non-competitively with ATP, once covalently bound to enzymes, which is advantageous in a pharmacokinetic manner in the presence of high intracellular ATP concentrations. Furthermore, they could increase their residence time on the kinase to obtain durable inhibition despite the decrease in the plasma 
concentrations of covalent drug, and avoid drug resistance during the development of mutations..$^{2526}$

In general, covalent inhibitors take effect through a two-step binding mode (Figure S1). Firstly, they form a reversible complex with the enzyme. This step is driven by the affinity of inhibitors to the enzyme. Then in the second step, the electrophilic group of the inhibitors attacks the targeted residue in the enzyme, forming a covalent bond. Based on the two-step process for kinase inhibition and a kinome-wide sequence analysis in connection with 3D structure of the ATP site, we have recently designed, characterized the first covalent inhibitor of FAK $\mathbf{7} \mathbf{a}_{1}$ (Table 1) and solved its co-crystal structure with FAK kinase domain in which it binds covalently to Cys427 from the glycine-rich loop closer to the ATP site, whereas this residue is not conserved in most of other human kinases. ${ }^{27}$ However, $7 \mathbf{a} 1$ was also highly active against some other protein tyrosine kinases (see Table 3). These off-target inhibitions are probably due to the extremely high affinity of the pyrimidine scaffold which is similar to the purine ring of ATP and well located in the ATP binding site for these kinases. In order to better understand the underlying mechanism of FAK signaling pathway in GBM progression, it is desirable to discover more selective FAK inhibitors. Previous studies demonstrated that VS-6062 (PF 562,271), an ATP-competitive inhibitor of FAK with an arylaminopyridylmethylaminopyrimidine motif had a good kinase selectivity profile on a panel of 42 kinases. ${ }^{28}$ The good selectivity resulted from a helical conformation of "DFG" induced by this motif. Thus, we tried to modify an arylamino group in the 
diarylaminopyrimidine scaffold with benzylamino or pyridylmethylamino groups to increase selectivity of our inhibitors.

On the other hand, it has been previously shown that $\alpha$-cyanoacrylamide-based Michael acceptors could be applied to design reversible covalent kinase inhibitors with improved pharmacological properties. ${ }^{29}$ The reversible nature of this modification, which still maintains the prolonged residence time of the inhibitor on the kinase of interest is likely to lower the risk of forming a permanent covalent adduct with off-target cysteine. Therefore, several $\alpha$-cyanoacrylamide-based warhead were introduced in our 2,4-diarylaminopyrimidine scaffold. We sought to explore the contribution of the binding affinity and the rate of covalent bond formation of these reversible covalent inhibitors. We expected this novel mechanism to hold promise for the development of FAK inhibitors with better therapeutic efficacy against human malignant GBM.

These compounds were designed based on the crystal structure of the covalent inhibitor 7a $\mathbf{a}_{1}$ (PDB ID: 6GCR) in order to fit the proposed binding mode with the FAK kinase domain. One set of compounds contains modifications in the high affinity region inside the ATP binding pocket (7b-g, Figure 2A) and another set is modified in the electrophilic warheads for the covalent bonding with Cys427 (7a, 9 9a-c, Figure 2B). Since compounds 9a-c contain relatively large substituents in the Michael group, we ensured the stereochemical compatibility of covalent bond formation with maintaining all high affinity interactions by molecular modeling. For this, the positions of the high affinity binding regions were fixed and the linker positions 
adjusted for covalent binding with Cys427. Stereochemical geometries were enforced using restraints calculated with PRODRG ${ }^{30}$ and the covalent linkage defined in JLigand. ${ }^{31}$ As shown in Figure S2, cyanoacrylamide electrophiles attached to the 2,4-diarylaminopyrimidine scaffold targeting FAK kinase were able to form a covalent bond with Cys427 in the similar manner as the covalent inhibitor of FAK 7a $\mathbf{a}_{1}$ and the substituted groups in the electrophilic warheads pointed away from Cys427 and the ATP binding cleft.

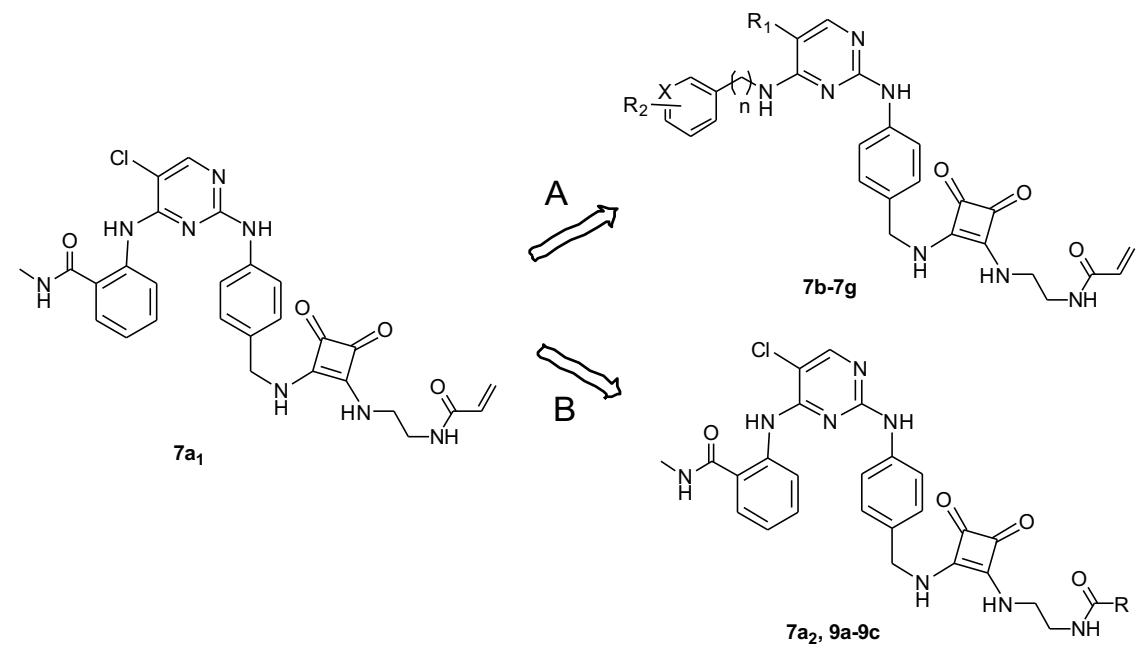

Figure 2. Design strategy of FAK covalent inhibitors

Herein, we present the structure-guided design of pyrimidine-based derivatives to covalently target FAK. The synthesis and biological evaluations provided a series of new analogues as covalent inhibitors of FAK based on our previously reported scaffold. These inhibitors showed a potent inhibition of $\mathrm{FAK}$ with $\mathrm{IC}_{50}$ values in the 
nanomolar range. They also strongly suppressed the proliferation of several human malignant glioma cell lines in which FAK expression was at high levels. Furthermore, these new inhibitors decreased the phosphorylation of Akt, Erk and NF- $x \mathrm{~B}$, induced glioma cell cycle arrest at the G2/M phase and inhibited the migration of U87-MG cells, indicating their therapeutic potential to treat human malignant glioblastomas.

\section{- CHEMISTRY}

Starting from commercially available 2,4,5-trichloropyrimidine, the first chlorine atom in position 4 of 2,4,5-trichloropyrimidine was substituted by 2-amino- $N$-methylbenzamide or 2-amino- $N$-methoxybenzamide in the presence of $\mathrm{NaHCO}_{3}$ in EtOH at reflux to provide monosubstituted intermediates 1a-b in a yield of 93\% (Schema 1). Compounds 1c-f were obtained in mild conditions at room temperature in the present of DIPEA in THF from the appropriate benzylamine derivatives. The subsequent nucleophilic substitution on position 2 of the pyrimidine ring of compounds $\mathbf{1}$ proceeded well with allyl (4-aminobenzyl)carbamate under acidic condition to give intermediates $\mathbf{2 a}$ and $\mathbf{2 c - f}$, except for $\mathbf{2} \mathbf{b}$ which was prepared using Pd-catalyzed Buchwald-Hartwig reaction with XantPhos as ligand. In contrast to 2,4,5-trichloropyrimidine, 2,4-dichloro-5-trifluoromethyl-pyrimidine yielded a 1:1 mixture of the two isomers for the first substitution. Thus, the expected isomer $\mathbf{3}$ was prepared by using a selective substitution of allyl (4-aminobenzyl)carbamate to 5-trifluoromethyl-2,4-dichloropyrimidine in the presence of zinc chloride, as described previously. ${ }^{32}$ Then, under the catalysis of hydrochloric acid intermediate $\mathbf{2} \mathbf{g}$ was obtained from $\mathbf{3}$ and 2-amino-N-methylbenzamide in a good yield. 


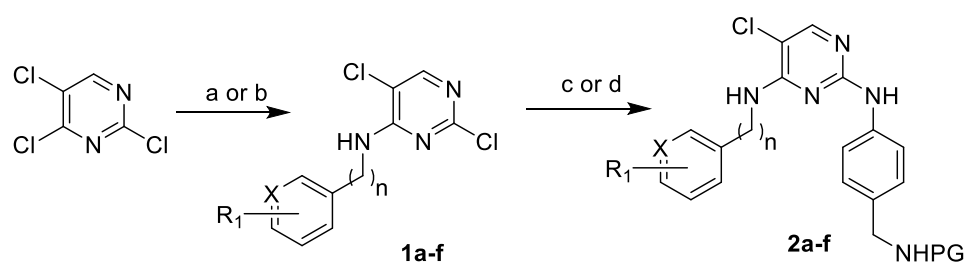

1a: $n=0, X=C H, R_{1}=2-\mathrm{CONHCH}_{3} \quad$ 2a: $n=0, X=C H, R_{1}=2-\mathrm{CONHCH}_{3}, \quad P G=A l l o c$

1b: $n=0, X=C H, R_{1}=2-\mathrm{CONHOCH}_{3} \quad$ 2b: $n=0, X=C H, R_{1}=2-\mathrm{CONHOCH}_{3}, \quad P G=B o c$

1c: $n=1, X=C H, R_{1}=2-N\left(C_{3}\right) S_{2} C_{3} \quad$ 2c: $n=1, X=C H, R_{1}=2-N\left(C_{3}\right) S_{2} C_{2} H_{3}, P G=A l l o c$

1d: $n=1, X=C H, R_{1}=3-N\left(C_{3}\right) S_{2} C_{3} \quad$ 2d: $n=1, X=C H, R_{1}=3-N\left(C_{3}\right) S_{2} C_{3}, P G=A l l o c$

1e: $n=1, X=C H, R_{1}=3-S_{2} \mathrm{CH}_{3} \quad$ 2e: $n=1, X=C H, R_{1}=3-S_{2} C_{3}, \quad P G=A l l o c$

1f: $n=1, X=N, \quad R_{1}=2-N\left(C_{3}\right) S_{2} C_{3} \quad 2 f: n=1, X=N, \quad R_{1}=2-N\left(C_{3}\right) S_{2} \mathrm{CH}_{3}, P G=A l l o c$

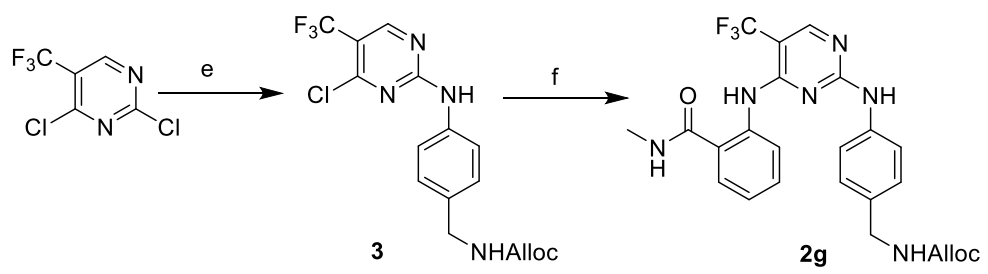

Scheme 1. Reagents and conditions: (a) substituted aniline, $\mathrm{NaHCO}_{3}, \mathrm{EtOH}$, reflux, overnight (for 1a-b); (b) benzylamine derivatives (or pyridin-3-ylmethanamine derivative for 1f), DIPEA, THF, rt, overnight, (for 1c-f); (c) allyl (4-aminobenzyl)carbamate, $\mathrm{HCl}$ in dioxane, $\mathrm{n}-\mathrm{BuOH}, 100{ }^{\circ} \mathrm{C}$, overnight, (for $\mathbf{2 a}$, 2c-2f); (d) tert-butyl (4-aminobenzyl)carbamate, $\mathrm{Pd}(\mathrm{dba})_{3}$, XantPhos, $\mathrm{Cs}_{2} \mathrm{CO}_{3}$, 1,4-dioxane, reflux, 24 h, (for 2b); (e) allyl (4-aminobenzyl)carbamate, zinc chloride, $\mathrm{Et}_{3} \mathrm{~N}, t-\mathrm{BuOH} / \mathrm{DCM}(1: 1), 0{ }^{\circ} \mathrm{C}-\mathrm{rt}, 6 \mathrm{~h}$; (f) 2-amino- $N$-methylbenzamide, $\mathrm{HCl}$ in dioxane, DMF, $90{ }^{\circ} \mathrm{C}, 7 \mathrm{~h}$.

The Alloc or Boc protecting group (PG) of compounds 2a-g were removed using typical methods affording $\mathbf{4 a - g}$ respectively. The primary amines of $\mathbf{4 a - g}$ were further condensed with tert-butyl (2-((2-methoxyl-3,4-dioxacyclobut-1-en-1-yl)amino)ethyl) carbamate (Scheme S1) in the presence of DIPEA at $75^{\circ} \mathrm{C}$, followed by deprotection 
of the Boc group to afford compounds 6a-g in good yields. Subsequently, acylation of the primary amine with acryloyl chloride or 2-chloroacetyl chloride gave the expected, targeted inhibitors 7a-g.
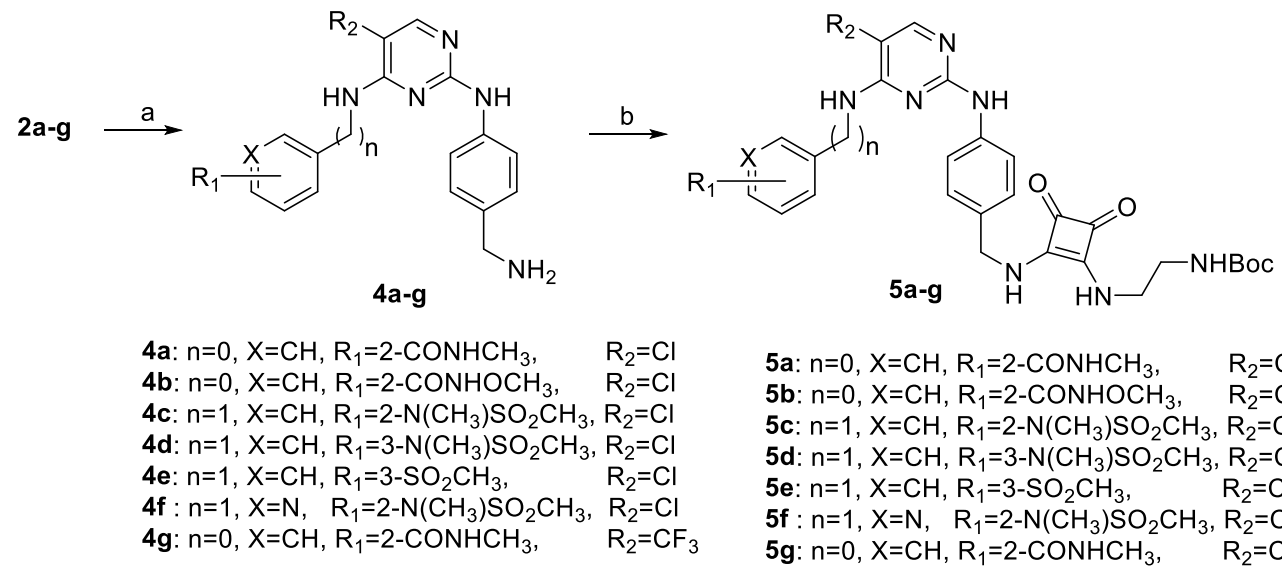

5a: $\mathrm{n}=0, \mathrm{X}=\mathrm{CH}, \mathrm{R}_{1}=2-\mathrm{CONHCH}_{3}, \quad \mathrm{R}_{2}=\mathrm{Cl}$ 5b: $n=0, X=C H, R_{1}=2-\mathrm{CONHOCH}_{3}, \quad \mathrm{R}_{2}=\mathrm{Cl}$ 5c: $n=1, X=C H, R_{1}=2-N\left(C_{3}\right) \mathrm{SO}_{2} \mathrm{CH}_{3}, \mathrm{R}_{2}=\mathrm{Cl}$ 5d: $n=1, X=C H, R_{1}=3-N\left(C_{3}\right) S_{2} C_{3}, R_{2}=\mathrm{Cl}$ 5e: $n=1, X=C H, R_{1}=3-S_{2} \mathrm{CH}_{3}, \quad \mathrm{R}_{2}=\mathrm{Cl}$ 5f: $n=1, X=N, \quad R_{1}=2-N\left(C_{3}\right) \mathrm{SO}_{2} \mathrm{CH}_{3}, \mathrm{R}_{2}=\mathrm{Cl}$ 5g: $\mathrm{n}=0, \mathrm{X}=\mathrm{CH}, \mathrm{R}_{1}=2-\mathrm{CONHCH}_{3}, \quad \mathrm{R}_{2}=\mathrm{CF}_{3}$
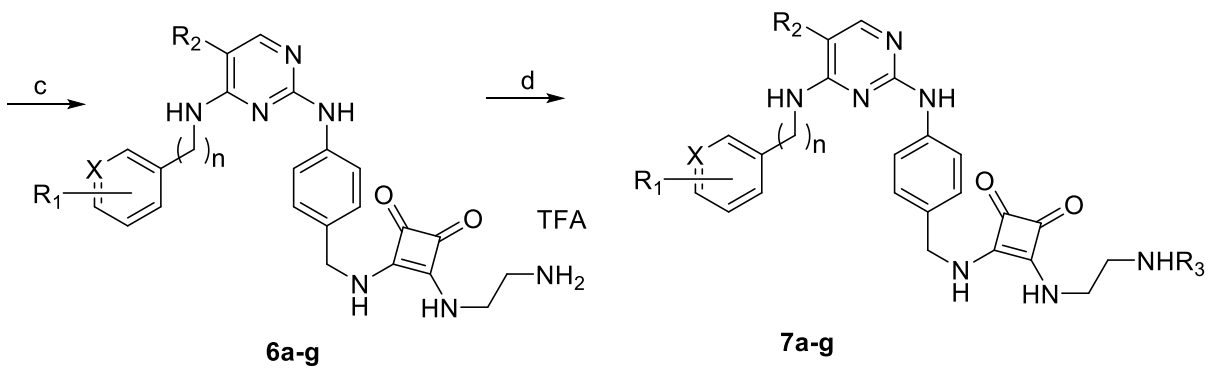

$7 a-9$

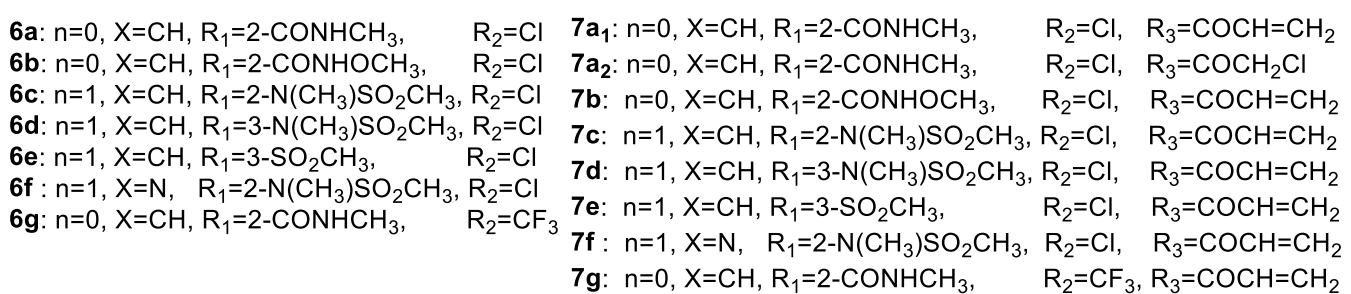

Scheme 2. Reagents and conditions: (a) morpholine, $\mathrm{Pd}\left(\mathrm{PPh}_{3}\right)_{4}$, THF or DMF, rt, $3 \mathrm{~h}$ (for 2a, 2c-g), or TFA/DCM (v/v=1/1), rt, 30 min (for 2b); (b) DIPEA, tert-butyl (2-((2-methoxyl-3,4-dioxacyclobut-1-en-1-yl)amino)ethyl)carbamate, DMF, $75{ }^{\circ} \mathrm{C}$, overnight; (c) TFA/DCM (v/v= 1/1), rt, $30 \mathrm{~min}$; (d) appropriate chloride (acryloyl chloride for $\mathbf{7} \mathbf{a}_{1}-\mathbf{g}, 2$-chloroacetyl chloride for $\left.7 \mathbf{a}_{2}\right), 0{ }^{\circ} \mathrm{C}-\mathrm{rt}, 12 \mathrm{~h}$. 
For the synthesis of reversible covalent inhibitors, cyanoacetic acid was coupled to the primary amine of $\mathbf{6 a}$ using EDCI and HOBT affording 8, which was subsequently condensed with appropriate aldehydes through Knoevenagel condensation yielding inhibitors 9 a-c.

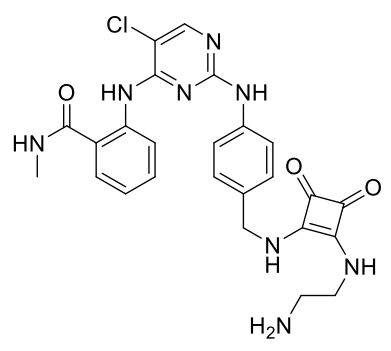

$6 a$

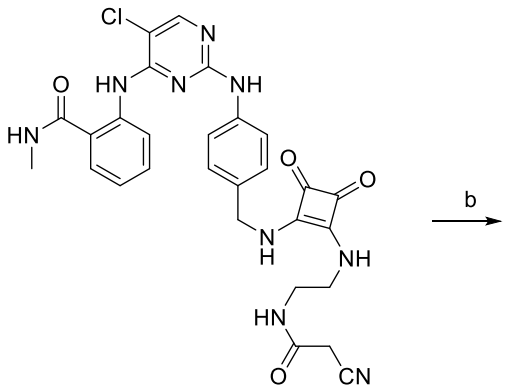

8

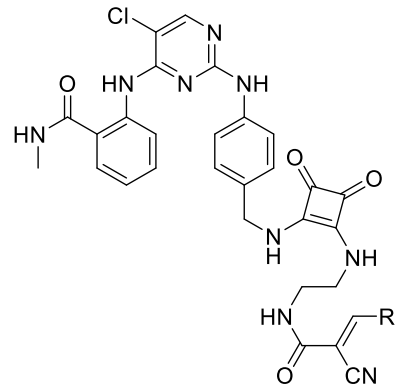

9a: $\mathrm{R}=\mathrm{Et}$

9b: $\mathrm{R}=\mathrm{CH}\left(\mathrm{CH}_{3}\right)_{2}$ 9c: $\mathrm{R}=\mathrm{CH}\left(\mathrm{CH}_{2}\right)_{2}$

Scheme 3. Reagents and conditions: (a) cyanoacetic acid, EDCI, HOBT, DIPEA, DMF, $0{ }^{\circ} \mathrm{C}$ - rt, overnight; (b) appropriate aldehyde, $\mathrm{AcOH}$, piperidine, $\mathrm{DMF}, 100{ }^{\circ} \mathrm{C}$, $2 \mathrm{~h}$.

\section{- RESULTS AND DISCUSSION}

\section{In Vitro inhibition of FAK enzymatic activity, kinetic study and reversibility}

of thiol addition. The inhibitory activity of the newly synthesized inhibitors against FAK was first evaluated using an ADP-Glo ${ }^{\text {TM }}$ kinase assay as reported previously..$^{27} \mathrm{~A}$ known ATP-competitive and reversible inhibitor of FAK, TAE-226 was included as a control in this assay.

As shown in Table 1, potency differences were observed among these compounds and most of them showed more potent inhibitory activity toward FAK kinase than 
TAE-226. Turning the warhead from acrylamide (compound $\mathbf{7} \mathbf{a}_{1}$ ) into chloromethylketone led to the compound $\mathbf{7} \mathbf{a}_{2}$ with decreased inhibitory potency. Replacing the amide group on the arylamine (ring B for compound $\mathbf{7} \mathbf{a}_{1}$ ) with an $N$-methoxy-amide moiety (compound $7 \mathbf{b}$ ) or switching chloro atom on the arylamine (ring A for compound $\mathbf{7} \mathbf{a}_{1}$ ) to $\mathrm{CF}_{3}$ group (compound $\mathbf{7 g}$ ) were not well tolerated and resulted in a decreased potency toward FAK activity. The replacement of $\mathrm{NH}$ group between the phenyl ring $\mathrm{B}$ and the pyrimidine group (ring $\mathrm{A}$ ) by a $\mathrm{NHCH}_{2}$ moiety leading to compounds 7c-f did not demonstrate an improved activity against FAK. Among them, the displacement of the $N$-methylmethanesulfonamide group from ortho (compound 7c) to meta position in the phenyl ring B (compound 7d) or replacing the phenyl ring B with pyridine (compound 7f) displayed the similar inhibitory potency on FAK kinase activity. However, the replacement of $N$-methylmethanesulfonamide group by methanesulfonyl group (compound 7e) was not favorable and led to a decreased inhibitory effect toward FAK. Finally, replacing the acrylamide (compound $\left.\mathbf{7} \mathbf{a}_{1}\right)$ with several more reactive warheads, $\alpha$-cyanoacrylamide-based groups leading to compounds 9a-c were well tolerated and resulted in only a marginal loss in potency.

Table 1. In Vitro Kinase Assay $\mathrm{IC}_{50}$ Values of Novel 2,4-diarylaminopyrimidines and 2-arylamino-4-arylmethylaminopyrimidines compared with TAE-226

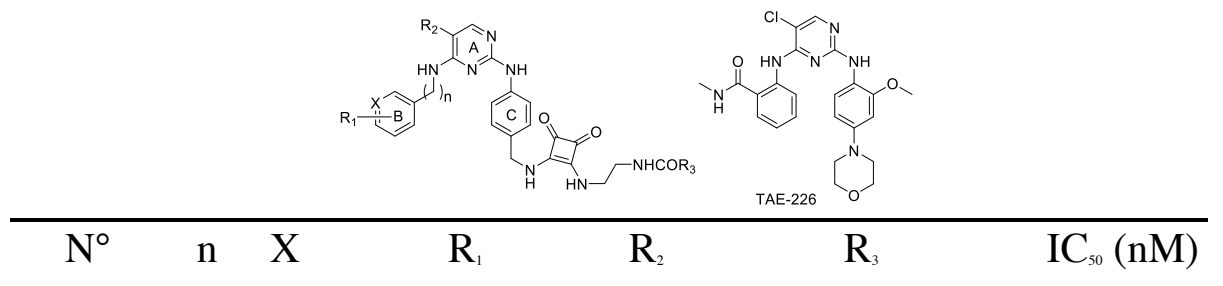




\begin{tabular}{|c|c|c|c|c|c|c|}
\hline $7 \mathbf{a}_{1}$ & 0 & $\mathrm{CH}$ & $2-\mathrm{CONHCH}_{3}$ & $\mathrm{Cl}$ & $\mathrm{CH}=\mathrm{CH}_{2}$ & $0.6 \pm 0.04$ \\
\hline $7 \mathbf{a}_{2}$ & 0 & $\mathrm{CH}$ & $2-\mathrm{CONHCH}_{3}$ & $\mathrm{Cl}$ & $\mathrm{CH}_{2} \mathrm{Cl}$ & $5.6 \pm 0.3$ \\
\hline $7 \mathbf{b}$ & 0 & $\mathrm{CH}$ & $2-\mathrm{CONHOCH}_{3}$ & $\mathrm{Cl}$ & $\mathrm{CH}=\mathrm{CH}_{2}$ & $3.7 \pm 0.2$ \\
\hline $7 c$ & 1 & $\mathrm{CH}$ & $2-\mathrm{N}\left(\mathrm{CH}_{3}\right) \mathrm{SO}_{2} \mathrm{CH}_{3}$ & $\mathrm{Cl}$ & $\mathrm{CH}=\mathrm{CH}_{2}$ & $4.6 \pm 0.5$ \\
\hline 7d & 1 & $\mathrm{CH}$ & $3-\mathrm{N}\left(\mathrm{CH}_{3}\right) \mathrm{SO}_{2} \mathrm{CH}_{3}$ & $\mathrm{Cl}$ & $\mathrm{CH}=\mathrm{CH}_{2}$ & $4.9 \pm 0.6$ \\
\hline $7 e$ & 1 & $\mathrm{CH}$ & $3-\mathrm{SO}_{2} \mathrm{CH}_{3}$ & $\mathrm{Cl}$ & $\mathrm{CH}=\mathrm{CH}_{2}$ & $16.3 \pm 1.5$ \\
\hline $7 f$ & 1 & $\mathrm{~N}$ & $2-\mathrm{N}\left(\mathrm{CH}_{3}\right) \mathrm{SO}_{2} \mathrm{CH}_{3}$ & $\mathrm{Cl}$ & $\mathrm{CH}=\mathrm{CH}_{2}$ & $5.5 \pm 0.4$ \\
\hline $7 \mathrm{~g}$ & 0 & $\mathrm{CH}$ & $2-\mathrm{CONHCH}_{3}$ & $\mathrm{CF}_{3}$ & $\mathrm{CH}=\mathrm{CH}_{2}$ & $6.8 \pm 0.7$ \\
\hline $9 a$ & 0 & $\mathrm{CH}$ & $2-\mathrm{CONHCH}_{3}$ & $\mathrm{Cl}$ & $\mathrm{C}(\mathrm{CN})=\mathrm{CHEt}$ & $2.5 \pm 0.2$ \\
\hline 9b & 0 & $\mathrm{CH}$ & $2-\mathrm{CONHCH}_{3}$ & \multicolumn{3}{|c|}{$\mathrm{Cl} \mathrm{C}(\mathrm{CN})=\mathrm{CHCH}\left(\mathrm{CH}_{3}\right)_{2} 1.2 \pm 0.1$} \\
\hline $9 c$ & 0 & $\mathrm{CH}$ & $2-\mathrm{CONHCH}_{3}$ & \multicolumn{3}{|c|}{$\mathrm{Cl} \mathrm{C}(\mathrm{CN})=\mathrm{CHCH}\left(\mathrm{CH}_{2}\right)_{2} 1.0 \pm 0.1$} \\
\hline E-2 & & & & & & $5.8 \pm 0.6$ \\
\hline
\end{tabular}

To quantitatively analyze the contribution of the reversible binding affinity and the rate of covalent bond formation to our covalent inhibitors, we evaluated $\mathrm{Ki}$ and $\boldsymbol{k}_{\text {mat }}$ parameters of our best compounds, which were realized by measuring $\mathrm{IC}_{50}$ values in a time-dependent manner. Interestingly, compounds $\mathbf{9 b - c}$ demonstrated the fastest rates of covalent formation among the tested compounds. Indeed, as shown in Table 2, compounds 9b-c showed $k_{\text {inact }}$ values of $0.25 \pm 0.03$ and $0.24 \pm 0.04 \mathrm{~min}^{-1}$, respectively, while compounds $7 \mathbf{a}_{1}$ and $7 \mathbf{g}$ displayed $0.16 \pm 0.02$ and $0.047 \pm 0.01 \mathrm{~min}^{-1}$.

Table 2: Kinetic study

\begin{tabular}{lccc}
\hline Compounds & $\mathrm{Ki}(\mathrm{nM})$ & $k_{\text {inct }}\left(\mathrm{min}^{-1}\right)$ & $k_{\text {inac }} / \mathrm{Ki}\left(\mu \mathrm{M}^{-1} \mathrm{~S}^{-1}\right)$ \\
\hline $\mathbf{7} \mathbf{a}_{1}$ & $0.23 \pm 0.03$ & $0.16 \pm 0.02$ & $11.6 \pm 3.40$ \\
$\mathbf{7 g}$ & $2.64 \pm 0.40$ & $0.047 \pm 0.01$ & $0.30 \pm 0.12$
\end{tabular}




$$
\begin{array}{llll}
\text { 9b } & 0.47 \pm 0.06 & 0.25 \pm 0.03 & 8.87 \pm 2.51 \\
\text { 9c } & 0.40 \pm 0.05 & 0.24 \pm 0.04 & 10.0 \pm 3.33
\end{array}
$$

Then, to confirm the reversible nature of compounds $\mathbf{9 b - c}$ and compare with compound $\mathbf{7} \mathbf{a}_{1}$, a $\beta$-mercaptoethanol addition to compound $\mathbf{9} \mathbf{c}$ or $\mathbf{7} \mathbf{a}_{1}$ was performed and monitored by LC-MS/MS method. As shown in Figure 3, when 9c was treated with $\beta$-mercaptoethanol, the adduct 11c was detected by LC-MS/MS (Figure S3, Table S1), indicating a 17:83 ratio of the adduct 11c to the starting compound 9c after $24 \mathrm{~h}$ treatment. A ten-fold dilution in buffer showed that the reaction was reversible, because the 11c/9c ratio decreased to $2: 98$. These results showed that an amide and a nitrile groups increased the acidity of its neighbor $\alpha \mathrm{H}$ in 11c and facilitated elimination of the thiol group of adduct 11c to recover 9c. These data are also consistent with the previously reported results that the addition of a thiol to 2-cyanoacrylate at physiological $\mathrm{pH}$ is a rapid-equilibrium reaction. ${ }^{33}$ Conversely, reaction of $\mathbf{7} \mathbf{a}_{1}$ with $\beta$-mercaptoethanol produced the stable adduct $\mathbf{1 0 \mathbf { a } _ { 1 }}$ with a ratio of 62:38 after $24 \mathrm{~h}$ and the ten-fold dilution experiment showed an increased of the ratio $\left(\mathbf{1 0 a} / 7 \mathbf{a}_{1}\right)$ to $81: 19$, in accordance with the irreversibility of this addition reaction.
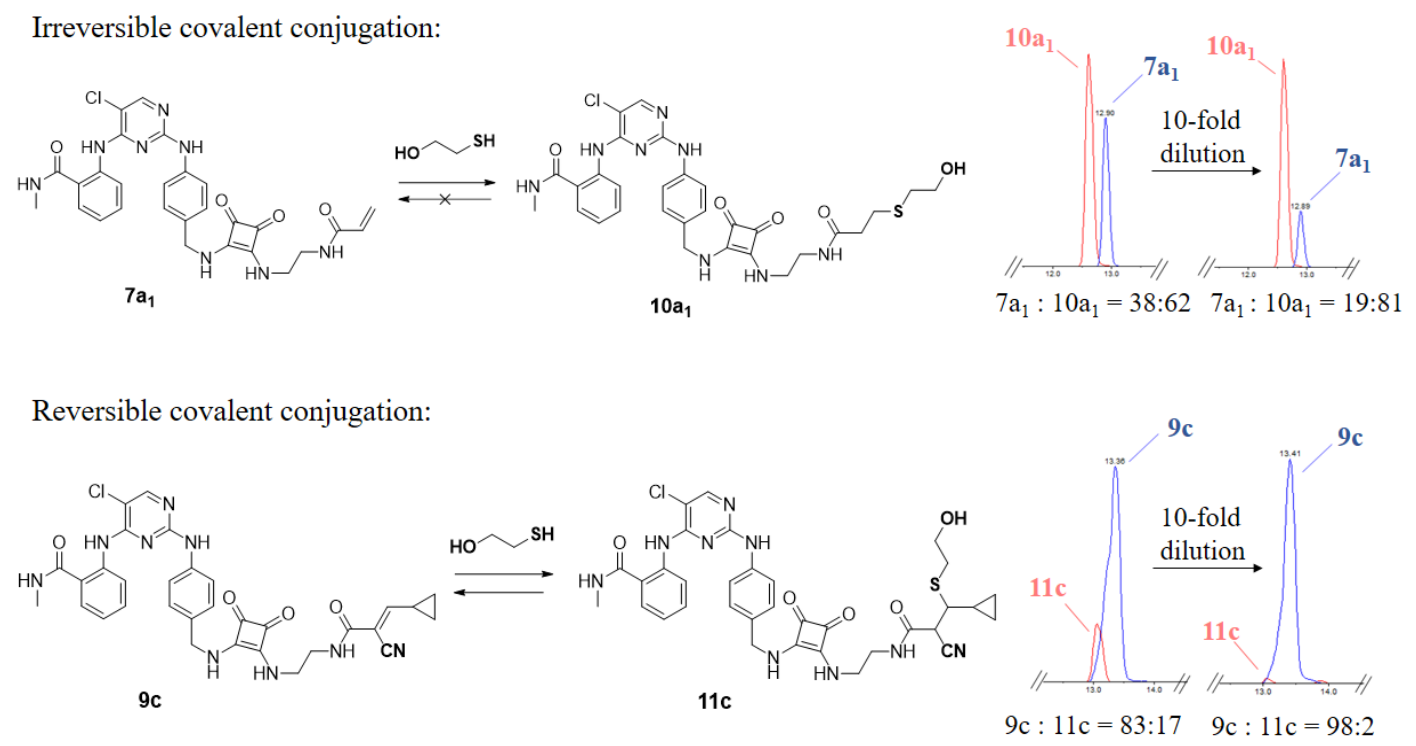

Figure 3. $\beta$-Mercaptoethanol addition to compounds $\mathbf{7} \mathbf{a}_{1}$ and $9 \mathbf{c}$ monitored by 


\section{LC-MS/MS}

Kinase selectivity profile. In order to investigate the selectivity of these covalent inhibitors, we evaluated the selected compounds $7 \mathbf{a}_{\mathbf{l}}, \mathbf{7 f}, \mathbf{7 g}$ and $9 \mathbf{b}$ in vitro against a panel of ten kinases (c-Src, FGFR1, c-kit, EGFR, IGF1R, PDGFR, IR, Akt, Erk and Pyk2). The assay was performed with human recombinant protein in the presence of $100 \mathrm{nM}$ of each compound by Eurofins Cerep, France, using a radiometric kinase activity assay protocol. As shown in Table 3, the results indicate that these inhibitors did not show any inhibition of c-kit at $100 \mathrm{nM}$ among the tested kinases. Otherwise, compound 7f only strongly inhibited two kinases, FAK and Pyk2, showing a good selectivity profile against the other tested kinases. In contrast, compounds $\mathbf{7} \mathbf{a}_{1}, \mathbf{7 g}$ and 9b were active against the majority of the kinases tested, such as FGFR1, IGF1-R, PDGFRA and EGFR, which are also involved in the pathogenesis of GBM..$^{3436}$ These off-target inhibitions are probably due to the extremely high affinity of diarylaminopyrimidine scaffold for these kinases.

It is well known that most of the kinase inhibitors as anti-cancer drugs in clinical use or in late development stages are multi-target kinase inhibitors (MTKIs). They could exert effective anti-tumor effects through modulating several different signaling pathways, minimize resistance from the inhibition of only one of oncogenic signaling pathways and give greater clinical efficacy and benefit. In fact, TAE-226 inhibited not only FAK enzymatic activity $\left(\mathrm{IC}_{50}=0.0054 \mu \mathrm{M}\right)$, but also several other protein tyrosine kinases including IGF-1R $\left(\mathrm{IC}_{50}=0.081 \mu \mathrm{M}\right)$, Ins-R $\left(\mathrm{IC}_{50}=0.043 \mu \mathrm{M}\right)$, FGFR-1 $\left(\mathrm{IC}_{50}=0.75 \mu \mathrm{M}\right)$, HER-1 $\left(\mathrm{IC}_{50}=0.55 \mu \mathrm{M}\right)$, HER-2 $\left(\mathrm{IC}_{50}=0.71 \mu \mathrm{M}\right)$, PDGFR- $\beta\left(\mathrm{IC}_{50}=2.6 \mu \mathrm{M}\right){ }^{37}$ However, this inhibitor efficiently suppressed glioma proliferation in vitro and in vivo, ${ }^{23}$ probably due to its ability to inhibit several aberrant signaling pathways in glioma. Thus, compounds $7 \mathbf{a}_{1}, 7 \mathbf{g}$ and $9 \mathbf{b}$ were selected in this study for further evaluation of their biological properties against human glioblastoma cell lines. 
Table 3. In vitro profile of compounds $7 \mathbf{a}_{1}, 7 \mathbf{f}, 7 \mathbf{g}$ and $9 \mathbf{b}$ against a panel of kinases

\begin{tabular}{ccccc}
\hline Kinases & $\mathbf{7 a 1}$ & $\mathbf{7 f}$ & $\mathbf{7 g}$ & $\mathbf{9 b}$ \\
\hline Src & $52.1 \%$ & $17.9 \%$ & $55.6 \%$ & $31.1 \%$ \\
FGFR1 & $87.1 \%$ & $32.5 \%$ & $88.3 \%$ & $83.5 \%$ \\
c-kit & $0.2 \%$ & $0 \%$ & $0.1 \%$ & $0 \%$ \\
EGFR & $47.2 \%$ & $1.2 \%$ & $29.0 \%$ & $25.1 \%$ \\
IGF1-R & $91.5 \%$ & $28.1 \%$ & $94.4 \%$ & $71.9 \%$ \\
PDGFRA & $91.0 \%$ & $12.5 \%$ & $78.4 \%$ & $67.5 \%$ \\
IR & $57.6 \%$ & $15.1 \%$ & $82.5 \%$ & $32.4 \%$ \\
Akt & $3.7 \%$ & $2.5 \%$ & $25.1 \%$ & $19.9 \%$ \\
Erk & $14.2 \%$ & $4.1 \%$ & $21.8 \%$ & $4.3 \%$ \\
Pyk2 & $97.6 \%$ & $68.3 \%$ & $99.8 \%$ & $97.5 \%$ \\
FAK & $98.1 \%$ & $92.2 \%$ & $98.6 \%$ & $94.1 \%$ \\
\hline
\end{tabular}

Inhibition at the dose of $100 \mathrm{nM}$

Inhibition of FAK autophosphorylation and covalent inhibition of FAK in

U-87 MG cells. Previous study showed that the autophosphorylation site, Tyr-397 of FAK is important for FAK-mediated signaling pathway and a key event for FAK biological functions. Thus, we investigated whether our selected compounds could affect FAK autophosphorylation in U-87 MG cells compared to TAE-226 as previously described ${ }^{38}$ As shown in Figure 4A, the autophosphorylation of FAK was significantly inhibited by treatment with inhibitors, $7 \mathbf{a}_{1}, \mathbf{7 g}, \mathbf{9 b}$ and $9 \mathbf{c}$ at low concentrations. In addition, these compounds could block Tyr397 phosphorylation in an obvious dose-dependent manner and most of them were more potent than TAE-226. This is consistent with their inhibitory activity against the FAK kinase in vitro. 
Furthermore, the inhibition of FAK autophosphorylation in U-87 MG with inhibitors $7 \mathbf{a}_{1}, 9 \mathbf{b}$ and $9 \mathbf{c}$ was confirmed by Western blotting (Figure 4B).

Then, we performed washout experiments to investigate the reversibility of the inhibition of FAK autophosphorylation at Tyr397. After a washing step with PBS to remove drug from the medium, FAK autophosphorylation process was recovered in the case of TAE-226 (Figure 4C), in accordance with its reversible characteristic. Conversely, under these conditions, U-87 MG cell treated with inhibitors $\mathbf{7} \mathbf{a}_{\mathbf{1}}, \mathbf{9 b}$ and 9c maintained potent inhibition of FAK phosphorylation (Figure 4C). The sustained inhibitory effects are likely due to covalent attachment of these compounds to FAK.

A
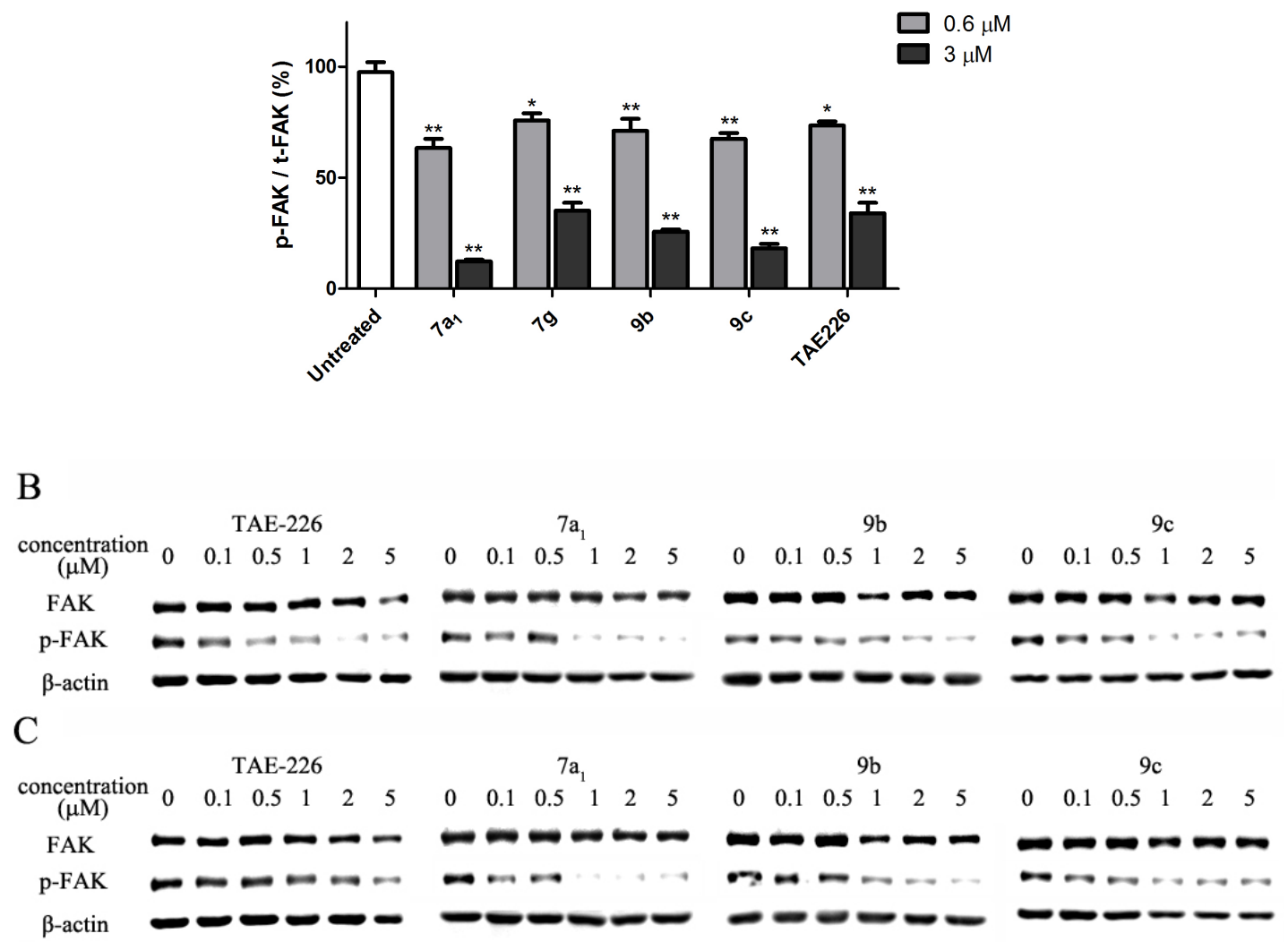
Figure 4. Inhibition of FAK autophosphorylation in U-87 MG cells. A) Cells were

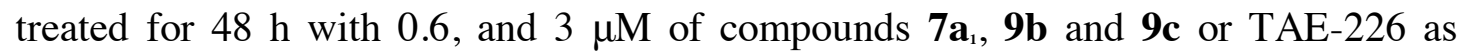

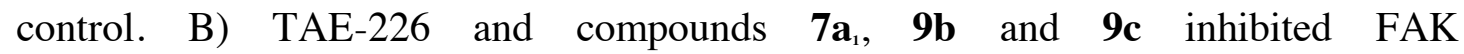

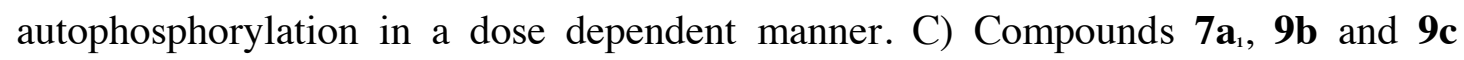
sustained inhibition of FAK autophosphorylation after washout experiments, which is not the case of TAE-226. Data obtained represent mean of triplicate readings of three independent experiments. ${ }^{*} p<0.05$ and ${ }^{* *} p<0.01$ compared with the control group.

\section{Effects of compounds $7 \mathrm{a}_{1}, 7 \mathrm{~g}, 9 \mathrm{~b}$ and $9 \mathrm{c}$ on Glioma cell proliferation, cell} morphology, apoptosis and cell cycle. To explore the antiproliferative effects of several selected compounds on glioblastoma cell lines, we used MTT assay and chose three human glioblastoma cell lines (U-87 MG, A172 and U251). As shown in Table 4 , the $\mathrm{IC}_{\mathrm{s0}}$ values of these inhibitors against the different tumor cells ranged between 0.13 and $9.8 \mu \mathrm{M}$. Among them, our compounds were more effective on A172 and $\mathrm{U} 251$ cell lines with $\mathrm{IC}_{50}$ values significantly lower than that of TAE-226, except for 9b which exhibited less cytotoxicity on U251 cells. On the contrary, TAE-226 was more efficient on U-87 MG cells than our compounds $\mathbf{9 b}$ and $9 \mathbf{c}$ in terms of survival decrease, except for $7 \mathbf{a}_{1}$ which displayed an $\mathrm{IC}_{50}$ value of $2.2 \mu \mathrm{M}$, slightly lower than that of TAE-226.

Table 4. Anti-proliferative Activity, $\mathrm{IC}_{\text {so }}(\mu \mathrm{M})$

Compounds $\quad$ U-87 MG A172 U251




\begin{tabular}{cccc}
$\mathbf{7 \mathbf { a } _ { 1 }}$ & $2.2 \pm 0.1$ & $0.65 \pm 0.05$ & $0.22 \pm 0.01$ \\
$\mathbf{7 g}$ & $3.3 \pm 0.4$ & $0.13 \pm 0.01$ & $0.15 \pm 0.02$ \\
$\mathbf{9 b}$ & $7.1 \pm 0.6$ & $1.3 \pm 0.02$ & $9.8 \pm 0.8$ \\
$\mathbf{9 c}$ & $7.2 \pm 0.5$ & $0.89 \pm 0.07$ & $1.2 \pm 0.01$ \\
TAE-226 & $2.9 \pm 0.4$ & $8.3 \pm 0.6$ & $6.3 \pm 0.5$ \\
\hline & & \\
all data represent mean \pm S.D. from different & \\
experiments performed in triplicate.
\end{tabular}

To further decipher the mechanism by which these compounds inhibit U-87 MG cellular proliferation, we first evaluated apoptosis by FACS analysis using Annexin V staining in the presence or absence of compounds $7 \mathbf{a}_{1}, 7 \mathbf{g}, 9 \mathbf{b}$ and $9 \mathbf{c}$, as compared with TAE-226. As shown in Figure 4A, we noted there was no change in apoptosis in U87 cells treated by the compounds up to $10 \mu \mathrm{M}$ concentration. This finding is consistent with previous results obtained in the case of an imidazo[1,2-a][1,3,5]triazine series ${ }^{38}$

On the other hand, cell fluorescence imaging of paxillin and actin was performed using U-87 MG cells treated with our inhibitors $7 \mathbf{a}_{1}, \mathbf{7 g}, \mathbf{9 b}, \mathbf{9 c}$ or TAE-226 at $1 \mu \mathrm{M}$ for 48 h. As shown in Fig. 4B, we observed the presence of multinucleated giant cells, which may be the result of nuclear division not being followed by cytokinesis, suggesting that these compounds would likely induce a cell cycle arrest. Previous studies had also reported that FAK inhibitors could induce cell multinucleation by suppressing furrowing and cytokinesis, which caused enhanced phagocytosis activity and significant changes in cyto/chemokine production. ${ }^{39}$ In addition, U-87 MG cells 
treated with our compounds had flat and enlarged morphology, which resembled in a state of cellular senescence. FAK is a scaffold protein localized to focal adhesions that link the extracellular matrix to the actin cytoskeleton and ensure the proper communication between the cell and the epithelial mesenchymal transition (ECM) during adhesion and migration. Focal adhesions are often connected to stress fibers, which are composed of bundles of 10-30 actin filaments and essential for cancer cell invasion and migration. ${ }^{40+1}$ It is worth to note that our inhibitors could stimulate the appearance of stress fibers in the similar manner as TAE-226 compared with untreated cells. Previous studies also showed that primary GBM cell lines treated with a MEK inhibitor, PD0325901 which displayed in vitro and in vivo efficacy of inhibiting tumor growth in an orthotopic mouse model of GBM, led to decreased motility and a significant change in cell shape and in the reorganization of actin from cortical into stress fibers. ${ }^{42}$ 
A

$7 \mathrm{a}_{1}$
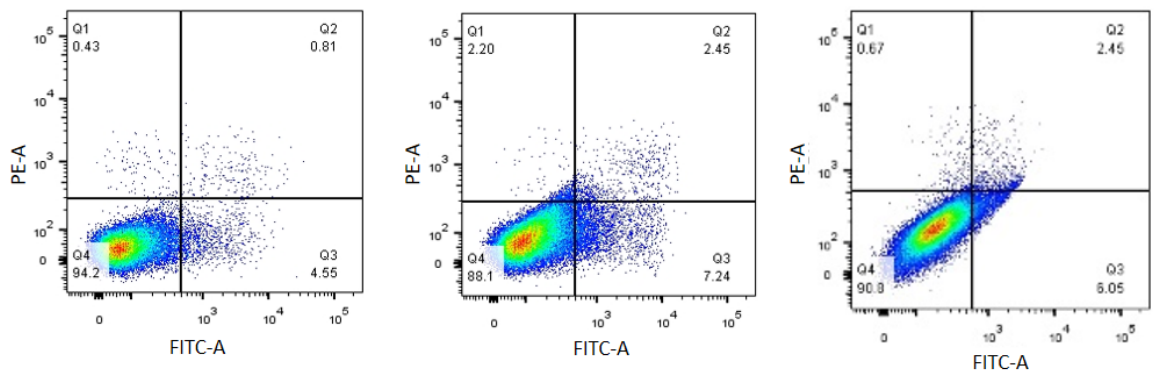

$7 g$

$9 b$

9c
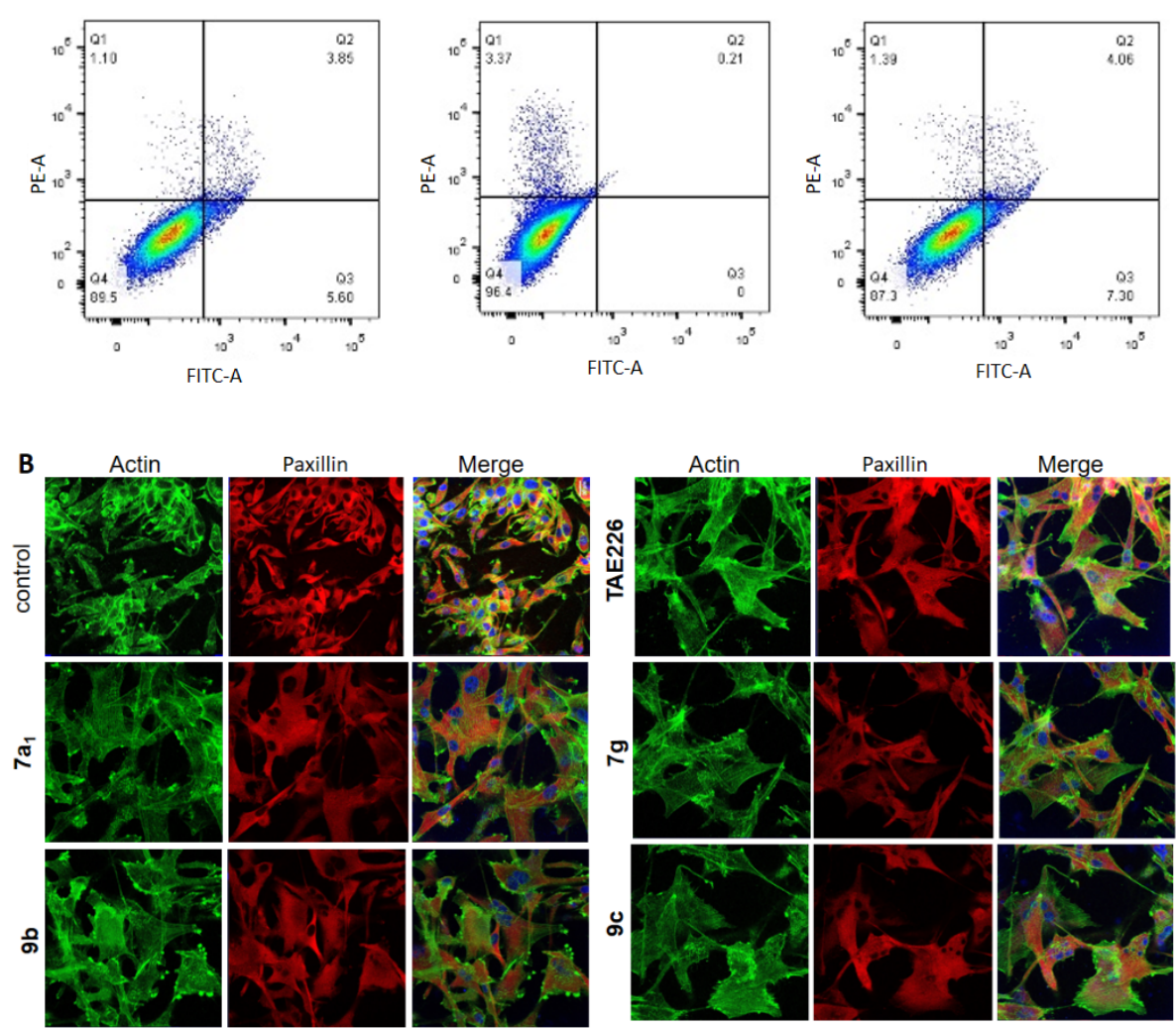

Figure 4. A) U-87 MG cells were plated at $10^{5}$ cells per well in a 6-well culture dish, incubated overnight, and then treated with $\mathbf{7} \mathbf{a}_{1}, \mathbf{7 g}, \mathbf{9 b}, \mathbf{9 c}$ or TAE-226 at $10 \mu \mathrm{M}$ for 48 h. Cells were stained with annexin V-FITC and propidium iodide and analyzed by FACS calibur. Cells were then classified as alive with no apoptosis (i.e., PE negative, annexin $\mathrm{V}$ negative), dead (i.e., PE positive), or apoptotic (i.e., annexin V positive). One representative experiment is shown. B) Immunofluorescence staining of U-87 MG cells treated with $\mathbf{7} \mathbf{a}_{1}, \mathbf{7 g}, \mathbf{9 b}, \mathbf{9 c}$ or TAE226 at $1 \mu \mathrm{M}$ for $48 \mathrm{~h}$. Nuclei were stained with Topro III. Organization of filamentous actin and paxillin was detected 
after staining with FITC-conjugated phalloidin and Paxillin antibody. Pictures were taken to depict the actin in green and the paxillin in red using a Zeiss microscope equipped with appropriate filters. Scale bar $=20 \mu \mathrm{m}$ Bar.

Then, cell cycle distribution was analyzed using flow cytometry and compounds $7 \mathbf{a}_{1}, 7 \mathbf{g}, 9 \mathbf{b}$ and $9 \mathbf{c}$ were used for the investigation compared with TAE-226 (Figure 5 and Figure S4). U-87 MG cells were treated either with or without 1 and $10 \mu \mathrm{M}$ of the inhibitors for $48 \mathrm{~h}$ and it was observed that the cell-cycle was blocked in the G2/M phases compared with the DMSO control. Indeed, for untreated cells, the live population of DNA contents in G0/G1 and G2/M were $51.6 \% \pm 4.3$ and $28.9 \% \pm 2.1$. When U-87 MG cells were exposed to compounds 7a1, 7g, 9b and 9c at $1 \mu \mathrm{M}$ for 48 $\mathrm{h}$, the population of cells in the G2-M phase markedly increased from $28.9 \% \pm 2.1$ to $80.8 \% \pm 6.7,75.1 \% \pm 5.2,79.1 \% \pm 6.4$, and $83.1 \% \pm 7.9$, respectively, while the population of cells in the G0/G1 phase decreased from $51.6 \% \pm 4.3$ to $9.2 \% \pm 1.2$, $13.7 \% \pm 1.9,12.7 \% \pm 1.3$, and $8.1 \% \pm 0.9$, respectively. In addition, when U-87 MG cells were treated with TAE-226 at the same concentration for $48 \mathrm{~h}$, we found that the live population of the DNA contents in G0/G1 and G2/M were $16.2 \% \pm 1.1$ and $66.1 \% \pm 3.7$, suggesting that our inhibitors $7 \mathbf{a 1}, \mathbf{7 g}, \mathbf{9 b}$ and $9 \mathbf{c}$ could disrupt the cell cycle progression and had more potent effect than TAE-226 on the G2/M phase of the cell cycle. 

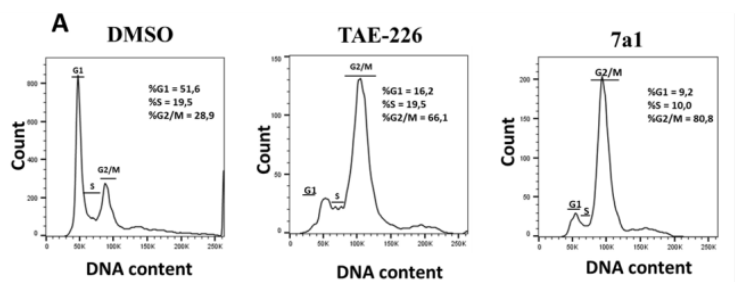

B
120
100
80
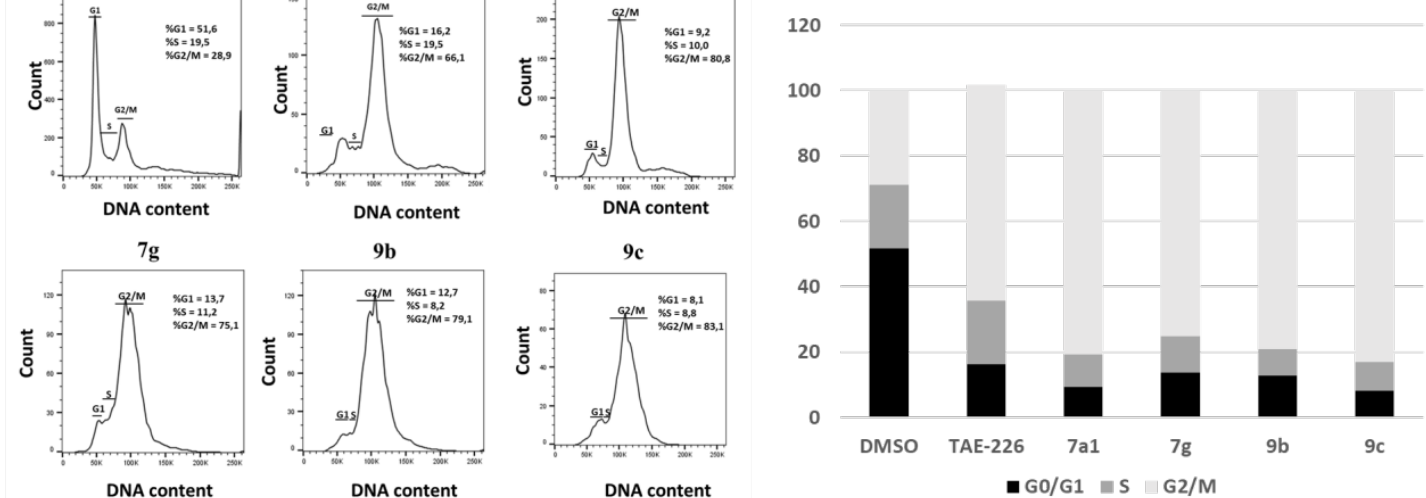

DNA content

DNA content

Figure 5. Cell cycle distribution in each phase was studied by flow cytometry: (A)

U-87 MG cells were plated at $10^{\text {s }}$ per well in a 6-well culture dish, incubated overnight, and then exposed to $\mathbf{7} \mathbf{a}_{\mathbf{1}}, \mathbf{7 g}, \mathbf{9 b}, \mathbf{9 c}$ or TAE-226 along with DMSO control for $24 \mathrm{~h}$. After incubation in $10 \%$ serum, cells were collected and stained with propidium iodide for cell cycle analysis. (B) Representative histograms of glioblastoma cells treated with $1 \mu \mathrm{M}$ of inhibitor show an increased $\mathrm{G} 2$ cell cycle fraction.

\section{Effects of inhibitors on the migration and inhibition of FAK suppress}

downstream signaling in U-87 MG cells. Cancer metastasis remains a major clinical problem in cancer diagnosis and treatment. Elevated levels of FAK, which play a key role in integrin mediated cell adhesion and migration as well as in advancing signaling from integrin to its downstream signaling partners, have been associated with the progression of multiple malignant tumors. We first determined the inhibitory effect on U-87 MG cell migration by our inhibitors using a scratch assay. As shown in Figure 6, upon creation of a new artificial gap on a confluent U-87 MG cell monolayer, certain sections within the scratched area were occupied by migrated cells 
with DMSO treatment after $24 \mathrm{~h}$ incubation, whereas the cells treated by our inhibitors moved more slowly toward the opening to close the newly created gap. Thus, the reduced rate of cell migration to the scratched defect suggests that our FAK inhibitors have a negative impact on cell mobility, which is in accordance with that observed in the stress fibers. In addition, these inhibitors, especially $\mathbf{7} \mathbf{a}_{1}$ and $\mathbf{9 c}$ demonstrated a stronger inhibitory activity than TAE-226 (Figure 6).

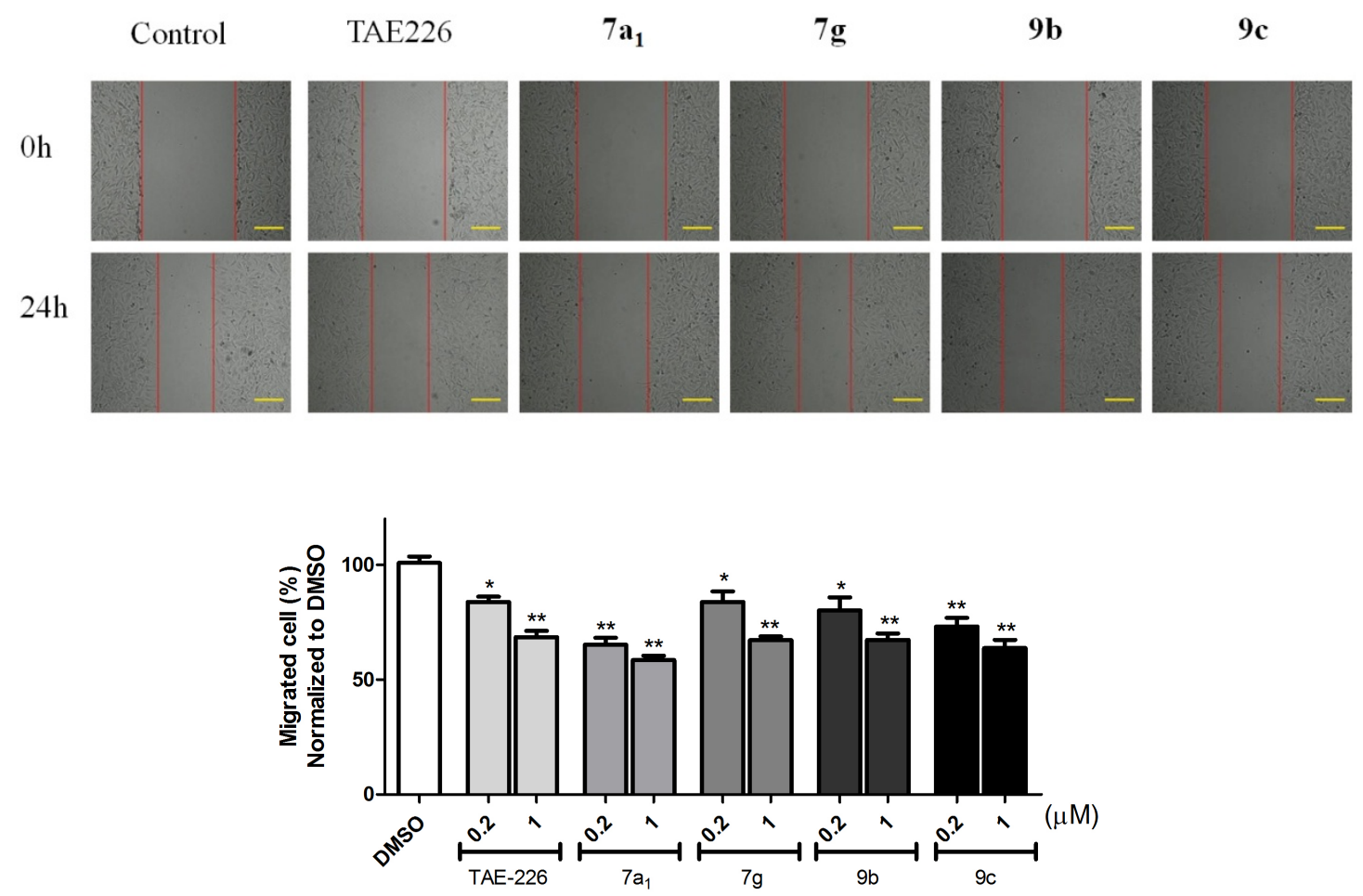

Figure 6. Effects of compounds $7 \mathbf{a}_{1}, 7 \mathbf{g}, 9 \mathbf{b}$ and $9 \mathbf{c}$ at 0.2 and $1 \mu \mathrm{M}$ on U-87 MG cell migration in a scratch-wound assay. Top, images of control and treatments at $0.2 \mu \mathrm{M}$, with time zero and $24 \mathrm{~h}$ scratch position marked. Scale bar $=250 \mu \mathrm{m}$. Bottom, quantification of migration. Representative data from three independent experiments. $* \mathrm{p}<0.05$ and $* * \mathrm{p}<0.01$ compared with the control group. 
Next, we explored downstream signaling proteins of FAK in U-87MG cells when treated by inhibitors $7 \mathbf{a}_{1}, 9 \mathbf{b}$ and $9 \mathbf{c}$ to understand which signalling pathways are involved in the growth of U-87 MG cells. As shown in Figure 7 by western blot analysis, these inhibitors suppressed the phosphorylation of FAK in a dose-dependent manner, which resulted in the decrease of Akt and Erk activities. Phosphorylation of Akt and Erk is a key modulator for cell survival and proliferation. There was little or no effect of inhibitors $\mathbf{7} \mathbf{a}_{1}$ and $\mathbf{9 b}$ on the activation of Akt and Erk (Table 3), suggesting that suppression of FAK activity by these inhibitors caused an inhibition in Akt and Erk phosphorylation. We focused further on the activation of Nuclear factor-kappaB (NF- $\varkappa \mathrm{B})$, a family of transcription factors. Evidence indicated that the degree of overexpression and activation of NF- $\varkappa \mathrm{B}$ is associated with glioma grade and $\mathrm{NF}-\varkappa \mathrm{B}$ activation could play a crucial role in the tumorigenesis and the progression of high-grade gliomas by promoting growth, proliferation, invasiveness, and angiogenesis. ${ }^{43}$ Western blot analysis was also used in this study to examine the activation status of NF- $\varkappa \mathrm{B}$ in GBM cells. Indeed, the strong positive immunostaining for activated diffuse cytoplasmic and scattered nuclear $p$-NF- $\varkappa \mathrm{B}$ was detected in untreated U-87 MG cells, and there was a significant correlation of the phosphorylation levels among p397FAK, $p$-NF- $\varkappa \mathrm{B}$ and $p$-Akt (Figure 7). Treatment of U-87 MG cells with our inhibitors resulted in a dose-dependent decrease in the levels of p397FAK, leading to a concomitant dose-dependent decrease of Akt and $\mathrm{NF}-\varkappa \mathrm{B}$ levels, especially in the case of $\mathbf{7} \mathbf{a}_{1}$. Thus, these data displayed that these inhibitors may suppress in part the proliferation of human malignant glioma cell lines 
through the inactivation of Akt/NF- $x \mathrm{~B}$ signaling pathways in GBM cells. Moreover, Akt is considered as a main mediator of the resistance to chemotherapy. Studies demonstrated that independent activation of Akt and NF- $\varkappa \mathrm{B}$ signaling pathways promoted the tumors resistant to chemotherapy.44 Therefore, the capability of these inhibitors to concomitantly reduce Akt and NF- $x \mathrm{~B}$ activities might offer an increased sensitivity of glioblastoma cells to chemotherapy and efficiently treat GBM.

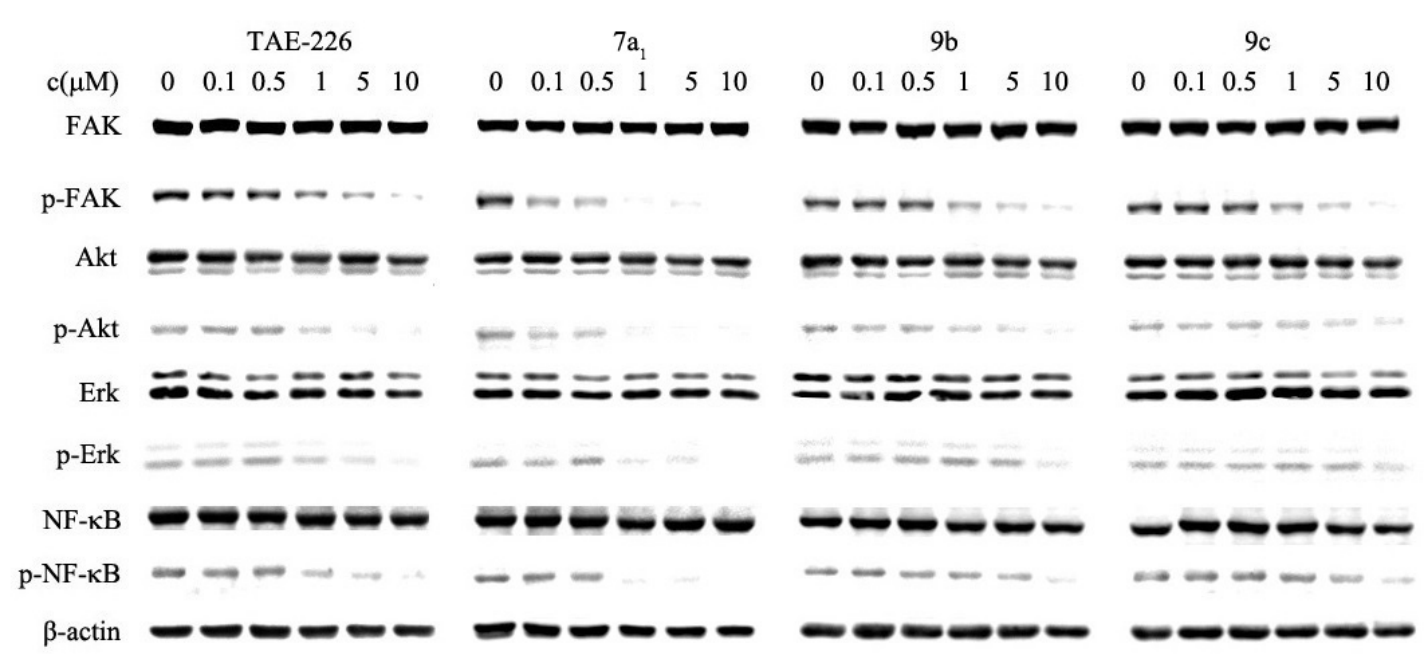

Figure 7. Effects of compounds $7 \mathbf{a}_{1}, 9 \mathbf{b}$ and $9 \mathbf{c}$ produced by the inhibition of FAK on FAK-mediated signal pathways compared with an ATP competitive FAK inhibitor, TAE-226.

\section{- CONCLUSION}

GBMs are highly lethal brain cancers and extremely resistant to conventional radiation and chemotherapies. Current therapy of these malignant gliomas remains essentially palliative and there is a great need for more efficient therapeutic strategies. In glioblastoma of patient, FAK is overexpressed and activated FAK promotes the 
tumor growth and invasion. Therefore, FAK kinase may offer a novel possibility for targeted therapy of glioblastomas. In this study, we developed a series of novel covalent inhibitors of the FAK kinase. These new compounds displayed highly potent inhibitory potency against $\mathrm{FAK}$ enzymatic activity with $\mathrm{IC}_{50}$ values in the nanomolar range. Several inhibitors delayed tumor growth in multiple human glioblastomas cell lines including U-87 MG, U251 and A172. They also significantly reduced the rate of cell migration and delayed cell cycle progression by stopping U87 cells in the G2/M phase. Furthermore, glioblastoma cells treated with these inhibitors showed a potent decrease of autophosphorylation of FAK and its downstream effectors Akt and Erk as well as nuclear factor-kappaB in a dose-dependent manner. These results exhibit the potential therapeutic benefits of covalent inhibitors of FAK for the treatment of human malignant gliomas and may offer a promising new targeted therapy for human glioblastomas.

\section{- EXPERIMENTAL SECTION}

General Information. All reagents were purchased without further purification unless otherwise noted. Reactions were monitored with thin layer chromatography (TLC) on commercial silica gel plate (GF254). Visualization of the developed plates was performed under UV light $(254 \mathrm{~nm})$. Flash column chromatography was performed on silica gel (200-300 mesh). Melting points were determined on a Kofler apparatus as uncorrected values. $\mathrm{H}$ and ${ }^{13} \mathrm{CNMR}$ spectra were recorded on 250 or 500 $\mathrm{MHz}$ NMR spectrometer at $25^{\circ} \mathrm{C}$. Chemical shifts $(\delta)$ are reported in ppm and 
referenced to an internal tetramethylsilane standard or to the residual peak DMSO- $d_{6}$ $\left(\delta\right.$ 2.50), $\mathrm{MeOD}\left(\delta\right.$ 3.31) or $\mathrm{CDCl}_{3}\left(\delta\right.$ 7.26) for ${ }^{1} \mathrm{H}$ NMR. Chemical shift of ${ }^{13} \mathrm{C}$ are reported relative to $\mathrm{CDCl}_{3}\left(\delta\right.$ 77.0), $\mathrm{MeOD}\left(\delta\right.$ 49.0) or DMSO- $d_{6}(\delta$ 39.5). The following abbreviations were used to describe peak-splitting patterns when appropriate: br s, broad singlet; s, singlet; d, doublet; t, triplet; q, quartet; and m, multiplet. Coupling constants, J, were reported in hertz units $(\mathrm{Hz})$. Purity of all compounds is $>95 \%$ as determined by HPLC on a Shimadzu LC-10AD system (Shimadzu, Kyoto, Japan), using an InertSustain ${ }^{\circledR} \mathrm{C} 18$ Column $(4.6$ x $250 \mathrm{~mm}, 5 \mu \mathrm{m})$ with mobile phase of water (solvent A) and $\mathrm{MeOH}$ (solvent B) and isocratic conditions: $0 \min (60 \% \mathrm{~A}$ and 40\% B), $5 \min (60 \% \mathrm{~A}$ and $40 \% \mathrm{~B}), 15 \min (5 \% \mathrm{~A}$ and $95 \% \mathrm{~B})$ and $20 \mathrm{~min}(5 \% \mathrm{~A}$ and $95 \% \mathrm{~B})$ at a flow rate of $1 \mathrm{~mL} / \mathrm{min}$. The eluted peaks were monitored at $254 \mathrm{~nm}$. High resolution mass spectra (HRMS) were carried out on Q-TOF Micro micromass positive ESI and APCI ion sources $(\mathrm{CV}=30 \mathrm{~V})$.

Human glioma (U-87 MG, A172 and U252) was purchased from American Type Culture Collection (ATCC). All cell lines were maintained as monolayer cultures at $37^{\circ} \mathrm{C}$ in a $5 \% \mathrm{CO}_{2}$ humidified incubator and in DMEM supplemented with $10 \%$ fetal bovine serum and 5\% Penicillin-Streptomycin.

General procedure for the synthesis of 1a-f. 2,4,5-trichloropyrimidine (1.0 eq) was added to a stirred solution of appropriate aniline (1.1 eq) and $\mathrm{NaHCO}_{3}(1.2 \mathrm{eq})$ in anhydrous $\mathrm{EtOH}$ at room temperature. The resulted mixture was heated to reflux and stirred overnight before cooled to room temperature. The precipitate was filtered out, washed with water give the desired product. Method B: Appropriate amine (1.1 eq) 
was added to a solution of 2,4,5-trichloropyrimidine (1 eq) in THF at room temperature, followed by DIPEA (1.5 eq) and the mixture was stirred for overnight. The solution was diluted with ethyl acetate and washed with water and brine. The organic phase was dried over $\mathrm{MgSO}_{4}$ and concentrated under reduced pressure. The residue was purified by silica column chromatography to give desired product.

2-((2,5-dichloropyrimidin-4-yl)amino)-N-methylbenzamide (1a). Yellowish solid, yield 93\%, mp 208 C. 'H NMR (250 MHz, DMSO- $\left.d_{6}\right) \delta 12.18(\mathrm{~s}, 1 \mathrm{H}), 8.86(\mathrm{~d}, J=$ $4.2 \mathrm{~Hz}, 1 \mathrm{H}), 8.52(\mathrm{~d}, J=8.0 \mathrm{~Hz}, 1 \mathrm{H}), 8.48(\mathrm{~s}, 1 \mathrm{H}), 7.80(\mathrm{dd}, J=7.9,1.3 \mathrm{~Hz}, 1 \mathrm{H})$, $7.60(\mathrm{t}, J=7.9 \mathrm{~Hz}, 1 \mathrm{H}), 7.23(\mathrm{t}, J=7.2 \mathrm{~Hz}, 1 \mathrm{H}), 2.81(\mathrm{~d}, J=4.5 \mathrm{~Hz}, 3 \mathrm{H})$. HRMS (ESI) $m / z$ calcd. for $\mathrm{C}_{12} \mathrm{H}_{11} \mathrm{Cl}_{2} \mathrm{~N}_{4} \mathrm{O}[\mathrm{M}+\mathrm{H}]+: 297.0310$, found: 297.0295 .

2-((2,5-dichloropyrimidin-4-yl)amino)-N-methoxybenzamide (1b). White solid, yield 77\%, mp 222 'C. 'H NMR (500 MHz, DMSO-d $) \delta 12.05(\mathrm{~s}, 1 \mathrm{H}), 11.34(\mathrm{~s}, 1 \mathrm{H})$, $8.47(\mathrm{~s}, 1 \mathrm{H}), 8.40(\mathrm{~d}, J=8.4 \mathrm{~Hz}, 1 \mathrm{H}), 7.69-7.56(\mathrm{~m}, 2 \mathrm{H}), 7.23(\mathrm{td}, J=7.6,1.2 \mathrm{~Hz}$, 1H), $3.72(\mathrm{~s}, 3 \mathrm{H}) .{ }^{{ }^{\prime} \mathrm{C}} \mathrm{NMR}\left(126 \mathrm{MHz}, \mathrm{DMSO}-d_{6}\right) \delta 165.53,156.65,156.33,155.40$, 137.82, 132.13, 127.95, 123.55, 121.72, 120.16, 114.76, 63.31. HRMS (ESI) $\mathrm{m} / \mathrm{z}$ calcd. for $\mathrm{C}_{12} \mathrm{H}_{11} \mathrm{Cl}_{2} \mathrm{~N}_{4} \mathrm{O}_{2}[\mathrm{M}+\mathrm{H}]+:$ : 313.02504, found: 313.02536 .

$N-(3-(((2,5-$ dichloropyrimidin-4-yl)amino)methyl)pyridin-2-yl)-N-methylmethane sulfonamide (1c). White solid, yield 92\%, mp $190{ }^{\circ} \mathrm{C} .{ }^{\prime} \mathrm{H}$ NMR (500 MHz, Chloroform- $d$ ) $\delta 8.45(\mathrm{dd}, J=4.7,1.9 \mathrm{~Hz}, 1 \mathrm{H}), 8.00(\mathrm{~s}, 1 \mathrm{H}), 7.96(\mathrm{dd}, J=7.7,1.9 \mathrm{~Hz}$, 1H), $7.32(\mathrm{dd}, J=7.7,4.7 \mathrm{~Hz}, 1 \mathrm{H}), 4.87(\mathrm{~s}, 2 \mathrm{H}), 3.31(\mathrm{~s}, 3 \mathrm{H}), 3.06(\mathrm{~s}, 3 \mathrm{H}) .{ }^{13} \mathrm{C}$ NMR $\left(126 \mathrm{MHz}, \mathrm{CDCl}_{3}\right) \delta 158.85,158.34,153.93,153.21,149.04,140.59,133.34,124.69$, 
113.70, 40.37, 38.02, 35.51. HRMS (ESI) $\mathrm{m} / \mathrm{z}$ calcd. for $\mathrm{C}_{12} \mathrm{H}_{14} \mathrm{O}_{2} \mathrm{~N}_{5} \mathrm{Cl}_{2} \mathrm{~S}[\mathrm{M}+\mathrm{H}]^{+}$: 362.02398, found: 362.02335 .

$N-(2-(((2,5-d i c h l o r o p y r i m i d i n-4-y l)$ amino $)$ methyl $)$ phenyl $)-N$-methylmethanesulfo namide (1d). White solid, yield 88\%, mp 177 C. 'H NMR (500 MHz, Chloroform- $d$ ) $\delta 7.97(\mathrm{~s}, 1 \mathrm{H}), 7.60-7.57(\mathrm{~m}, 1 \mathrm{H}), 7.38-7.35(\mathrm{~m}, 2 \mathrm{H}), 7.30-7.27(\mathrm{~m}, 1 \mathrm{H}), 4.51(\mathrm{~d}, J=$ $15.7 \mathrm{~Hz}, 2 \mathrm{H}), 3.31(\mathrm{~s}, 3 \mathrm{H}), 3.00(\mathrm{~s}, 3 \mathrm{H}) .{ }^{\mathrm{B}} \mathrm{C} \mathrm{NMR}\left(126 \mathrm{MHz}, \mathrm{CDCl}_{3}\right) \delta 158.76$, $158.34,153.65,140.14,138.42,131.73,129.56,129.45,126.35,113.56,40.40,39.61$, 35.56. HRMS (ESI) $m / z$ calcd. for $\mathrm{C}_{13} \mathrm{H}_{15} \mathrm{O}_{2} \mathrm{~N}_{4} \mathrm{Cl}_{2} \mathrm{~S}[\mathrm{M}+\mathrm{H}]^{+}: 361.02873$, found: 361.02857.

$N-(3-(((2,5-d i c h l o r o p y r i m i d i n-4-y l)$ amino $)$ methyl $)$ phenyl $)-N$-methylmethanesulfo namide (1e). White solid, yield 76\%, mp $154{ }^{\circ} \mathrm{C} .{ }^{\prime} \mathrm{H}$ NMR (500 MHz, Chloroform- $d$ ) $\delta 7.90(\mathrm{~s}, 1 \mathrm{H}), 7.27-7.21(\mathrm{~m}, 2 \mathrm{H}), 7.19-7.10(\mathrm{~m}, 2 \mathrm{H}), 5.77(\mathrm{t}, J=5.9 \mathrm{~Hz}, 1 \mathrm{H}), 4.56$ $(\mathrm{d}, J=5.9 \mathrm{~Hz}, 2 \mathrm{H}), 3.18(\mathrm{~s}, 3 \mathrm{H}), 2.70(\mathrm{~s}, 3 \mathrm{H}) .{ }^{\mathrm{r}} \mathrm{C} \mathrm{NMR}\left(126 \mathrm{MHz}, \mathrm{CDCl}_{3}\right) \delta 158.80$, $158.52,154.00,142.01,138.81,129.92,126.98,126.21,125.42,113.43,44.92,38.19$, 35.57. HRMS (ESI) $\mathrm{m} / z$ calcd. for $\mathrm{C}_{13} \mathrm{H}_{15} \mathrm{O}_{2} \mathrm{~N}_{4} \mathrm{Cl}_{2} \mathrm{~S}[\mathrm{M}+\mathrm{H}]^{+}: 361.02873$, found: 361.02863.

2,5-dichloro-N-(3-(methylsulfonyl)benzyl)pyrimidin-4-amine (1f). White solid, yield $83 \%$, mp $148{ }^{\circ} \mathrm{C} . '{ }^{H}$ NMR (500 MHz, Chloroform- $d$ ) $\delta 8.03(\mathrm{~s}, 1 \mathrm{H}), 7.91(\mathrm{~d}, J=$ $1.7 \mathrm{~Hz}, 1 \mathrm{H}), 7.84(\mathrm{dt}, J=7.9,1.4 \mathrm{~Hz}, 1 \mathrm{H}), 7.65(\mathrm{~d}, J=7.7 \mathrm{~Hz}, 1 \mathrm{H}), 7.54(\mathrm{t}, J=7.7$ $\mathrm{Hz}, 1 \mathrm{H}), 4.78(\mathrm{~d}, J=6.0 \mathrm{~Hz}, 2 \mathrm{H}), 3.05(\mathrm{~s}, 3 \mathrm{H}) .{ }^{\mathrm{B}} \mathrm{C} \mathrm{NMR}\left(126 \mathrm{MHz}, \mathrm{CDCl}_{3}\right) \delta 158.80$, $158.41,154.08,141.03,139.44,133.39,129.96,126.85,126.72,113.47,44.54,44.47$. HRMS (ESI) $m / z$ calcd. for $\mathrm{C}_{12} \mathrm{H}_{12} \mathrm{O}_{2} \mathrm{~N}_{3} \mathrm{Cl}_{2} \mathrm{~S}[\mathrm{M}+\mathrm{H}]^{+}: 332.00218$, found: 332.00168 . 
General procedure for the synthesis of $2 \mathbf{a}, \mathbf{2 c - f}$. To a solution of appropriate 4-aminosubstituted 2,5-dichloropyrimidine $\quad(1.0 \quad$ eq $)$ in $n$ - $\mathrm{BuOH}$, allyl (4-aminobenzyl)carbamate (1.0 eq) and $\mathrm{HCl}$ (4 $\mathrm{M}$ in dioxane, $1.0 \mathrm{eq})$ were added. The mixtures were heated at $100{ }^{\circ} \mathrm{C}$ overnight. After cooled to room temperature, the solution was diluted with DCM, and washed with $1 \mathrm{M} \mathrm{K}_{2} \mathrm{CO}_{3}$, brine and dried over $\mathrm{MgSO}_{4}$. The organic phase was concentrated under reduced pressure. The residue was purified through silica gel column chromatography to give desired product.

Allyl (4-((5-chloro-4-((2-(methylcarbamoyl)phenyl)amino)pyrimidin-2-yl)amino) benzyl)carbamate (2a). White solid, yield 44\%, mp $229{ }^{\circ} \mathrm{C} .{ }^{\prime} \mathrm{H}$ NMR (500 MHz, DMSO- $\left.d_{6}\right) \delta 11.60(\mathrm{~s}, 1 \mathrm{H}), 9.42(\mathrm{~s}, 1 \mathrm{H}), 8.79-8.68(\mathrm{~m}, 2 \mathrm{H}), 8.21(\mathrm{~s}, 1 \mathrm{H}), 7.76(\mathrm{dd}, J$ $=8.0,1.6 \mathrm{~Hz}, 1 \mathrm{H}), 7.70(\mathrm{t}, J=6.2 \mathrm{~Hz}, 1 \mathrm{H}), 7.62-7.57(\mathrm{~m}, 2 \mathrm{H}), 7.48(\mathrm{ddd}, J=8.7$, 7.3, 1.6 Hz, 1H), $7.19-7.10(\mathrm{~m}, 3 \mathrm{H}), 5.93(\mathrm{ddt}, J=17.3,10.6,5.3 \mathrm{~Hz}, 1 \mathrm{H}), 5.34-$ $5.13(\mathrm{~m}, 2 \mathrm{H}), 4.50(\mathrm{dt}, J=5.4,1.6 \mathrm{~Hz}, 2 \mathrm{H}), 4.15(\mathrm{~d}, J=6.2 \mathrm{~Hz}, 2 \mathrm{H}), 2.81(\mathrm{~d}, J=4.5$ $\mathrm{Hz}, 3 \mathrm{H}) .{ }^{\mathrm{C}} \mathrm{C} \mathrm{NMR}(126 \mathrm{MHz}, \mathrm{DMSO}) \delta 168.88,157.73,156.12,154.96,154.58$, $139.28,138.90,133.80,133.06,131.38,127.94,127.21,121.88,121.42,120.73$, 119.65, 116.85, 104.99, 64.28, 43.46, 26.28. HRMS (ESI) $m / z$ calcd. for $\mathrm{C}_{23} \mathrm{H}_{24} \mathrm{O}_{3} \mathrm{~N}_{6} \mathrm{Cl}$ $[\mathrm{M}+\mathrm{H}]^{+}: 467.15984$, found: 467.16043 .

Allyl(4-((5-chloro-4-(((2-(N-methylmethylsulfonamido)pyridin-3-yl)methyl)amino ) pyrimidin-2-yl)amino)benzyl)carbamate (2c). Pale foamy solid, yield 86\%, mp 100 ${ }^{\circ} \mathrm{C} .{ }^{\prime} \mathrm{H}$ NMR $\left(500 \mathrm{MHz}\right.$, Methanol- $\left.d_{4}\right) \delta 8.40(\mathrm{dd}, J=4.8,1.8 \mathrm{~Hz}, 1 \mathrm{H}), 7.86(\mathrm{~s}, 1 \mathrm{H})$, $7.77(\mathrm{dd}, J=7.7,1.8 \mathrm{~Hz}, 1 \mathrm{H}), 7.35-7.28(\mathrm{~m}, 3 \mathrm{H}), 7.05(\mathrm{~d}, J=8.2 \mathrm{~Hz}, 2 \mathrm{H}), 5.94$ (ddd, $J=15.5,10.5,5.2 \mathrm{~Hz}, 1 \mathrm{H}), 5.34-5.25(\mathrm{~m}, 1 \mathrm{H}), 5.21-5.13(\mathrm{~m}, 1 \mathrm{H}), 4.84(\mathrm{~s}, 2 \mathrm{H})$, 
4.58-4.52 (m, 2H), $4.18(\mathrm{~s}, 2 \mathrm{H}), 3.18(\mathrm{~s}, 3 \mathrm{H}), 3.12$ (s, 3H). ${ }^{\mathrm{C}} \mathrm{C}$ NMR (126 MHz, MeOD) $\delta 159.59,158.79,153.99,153.87,148.70,140.47,138.99,135.87,134.53$, 134.06, 128.63, 125.33, 120.74, 117.48, 116.65, 105.56, 66.41, 45.06, 41.49, 37.94, 36.38. HRMS (ESI) $\mathrm{m} / z$ calcd. for $\mathrm{C}_{23} \mathrm{H}_{27} \mathrm{O}_{4} \mathrm{~N}_{7} \mathrm{ClS} \quad[\mathrm{M}+\mathrm{H}]+$ : 532.15283, found: 532.15167.

Allyl(4-((5-chloro-4-((2-(N-methylmethylsulfonamido)benzyl)amino)pyrimidin-2-

yl) amino)benzyl)carbamate (2d). Pale solid, yield 64\%, mp $110{ }^{\circ} \mathrm{C} .{ }^{\prime} \mathrm{H}$ NMR (500 MHz, Chloroform- $d$ ) $\delta 7.88(\mathrm{~s}, 1 \mathrm{H}), 7.55-7.47$ (m, 3H), 7.38-7.27 (m, 3H), 7.22$7.15(\mathrm{~m}, 3 \mathrm{H}), 6.17(\mathrm{t}, J=6.1 \mathrm{~Hz}, 1 \mathrm{H}), 5.92(\mathrm{ddt}, J=16.3,10.8,5.6 \mathrm{~Hz}, 1 \mathrm{H})$, 5.34-5.19 (m, 2H), $5.07(\mathrm{t}, J=6.2 \mathrm{~Hz}, 2 \mathrm{H}), 4.64(\mathrm{br}, 1 \mathrm{H}), 4.59(\mathrm{~d}, J=5.7 \mathrm{~Hz}, 2 \mathrm{H})$, $4.30(\mathrm{~d}, J=5.9 \mathrm{~Hz}, 2 \mathrm{H}), 3.27(\mathrm{~s}, 3 \mathrm{H}), 2.99(\mathrm{~s}, 3 \mathrm{H}) .{ }^{\mathrm{B}} \mathrm{C} \mathrm{NMR}\left(126 \mathrm{MHz}, \mathrm{CDCl}_{3}\right) \delta$ $158.07,157.91,156.35,153.17,139.92,139.40,139.37,133.03,132.08,130.94$, $129.42,128.97,128.34,126.48,119.54,117.80,105.27,65.75,44.87,40.61,39.47$, 35.74. HRMS (ESI) $\mathrm{m} / z$ calcd. for $\mathrm{C}_{24} \mathrm{H}_{28} \mathrm{O}_{4} \mathrm{~N}_{6} \mathrm{ClS}[\mathrm{M}+\mathrm{H}]+$ : 531.15758, found: 531.15652 .

Allyl(4-((5-chloro-4-((3-(N-methylmethylsulfonamido)benzyl)amino)pyrimidin-2yl) amino)benzyl)-carbamate (2e). White solid, yield 62\%, mp $177{ }^{\circ} \mathrm{C}$. 'H NMR (500 MHz, DMSO- $\left.d_{6}\right) \delta 7.96(\mathrm{~s}, 1 \mathrm{H}), 7.81(\mathrm{t}, J=6.2 \mathrm{~Hz}, 1 \mathrm{H}), 7.63(\mathrm{~s}, 1 \mathrm{H}), 7.52(\mathrm{~d}, J=8.4$ $\mathrm{Hz}, 2 \mathrm{H}), 7.41(\mathrm{t}, J=2.0 \mathrm{~Hz}, 1 \mathrm{H}), 7.35(\mathrm{t}, J=7.8 \mathrm{~Hz}, 1 \mathrm{H}), 7.26(\mathrm{dt}, J=7.5,2.1 \mathrm{~Hz}$, 2H), $7.07(\mathrm{~d}, J=8.3 \mathrm{~Hz}, 2 \mathrm{H}), 5.91(\mathrm{ddd}, J=16.1,10.7,5.3 \mathrm{~Hz}, 1 \mathrm{H}), 5.31-5.14(\mathrm{~m}$, 2H), $4.63(\mathrm{~d}, J=5.9 \mathrm{~Hz}, 2 \mathrm{H}), 4.49(\mathrm{dt}, J=5.4,1.7 \mathrm{~Hz}, 2 \mathrm{H}), 4.09(\mathrm{~d}, J=5.7 \mathrm{~Hz}, 2 \mathrm{H})$, $3.16(\mathrm{~s}, 3 \mathrm{H}), 2.86(\mathrm{~s}, 3 \mathrm{H}) .{ }^{1 \mathrm{C}} \mathrm{NMR}(126 \mathrm{MHz}, \mathrm{DMSO}-d 6) \delta 157.89,157.34,156.08$, 
$153.22,141.59,140.74,139.37,133.78,132.17,128.90,127.14,125.64,125.03$, 124.61, 118.51, 116.87, 103.41, 64.26, 43.42, 43.30, 37.75, 34.86. HRMS (ESI) $\mathrm{m} / \mathrm{z}$ calcd. for $\mathrm{C}_{24} \mathrm{H}_{28} \mathrm{O}_{4} \mathrm{~N}_{6} \mathrm{ClS}[\mathrm{M}+\mathrm{H}]+: 531.15758$, found: 531.15627 .

Allyl(4-((5-chloro-4-((3-(methylsulfonyl)benzyl)amino)pyrimidin-2-yl)amino)benz $y l)$ carbamate (2f). White solid, yield 55\%, mp $169{ }^{\circ} \mathrm{C} .{ }^{\prime} \mathrm{H}$ NMR (500 MHz, Chloroform- $d) \delta 7.93(\mathrm{~s}, 1 \mathrm{H}), 7.92(\mathrm{~d}, J=1.8 \mathrm{~Hz}, 1 \mathrm{H}), 7.84(\mathrm{dt}, J=7.8,1.5 \mathrm{~Hz}, 1 \mathrm{H})$, $7.62(\mathrm{dt}, J=8.0,1.3 \mathrm{~Hz}, 1 \mathrm{H}), 7.55(\mathrm{t}, J=7.7 \mathrm{~Hz}, 1 \mathrm{H}), 7.44-7.37(\mathrm{~m}, 2 \mathrm{H}), 7.18(\mathrm{~d}, J=$ $8.1 \mathrm{~Hz}, 2 \mathrm{H}), 7.05(\mathrm{~s}, 1 \mathrm{H}), 5.93(\mathrm{ddt}, J=17.2,10.4,5.6 \mathrm{~Hz}, 1 \mathrm{H}), 5.80(\mathrm{t}, J=6.1 \mathrm{~Hz}$, 1H), 5.34-5.18 (m, 3H), $4.77(\mathrm{~d}, J=6.1 \mathrm{~Hz}, 2 \mathrm{H}), 4.59(\mathrm{~d}, J=5.6 \mathrm{~Hz}, 2 \mathrm{H}), 4.31(\mathrm{~d}, J$ $=6.0 \mathrm{~Hz}, 2 \mathrm{H}), 2.96(\mathrm{~s}, 3 \mathrm{H}) .{ }^{\mathrm{r}} \mathrm{C} \mathrm{NMR}\left(126 \mathrm{MHz}, \mathrm{CDCl}_{3}\right) \delta 158.04,157.83,156.43$, $153.69,141.08,140.51,138.92,133.08,132.69,132.62,129.93,128.31,126.55$, 126.52, 119.63, 117.75, 105.05, 65.98, 44.80, 44.55, 44.50. HRMS (ESI) $\mathrm{m} / z$ calcd. for $\mathrm{C}_{23} \mathrm{H}_{25} \mathrm{O}_{4} \mathrm{~N}_{5} \mathrm{ClS}[\mathrm{M}+\mathrm{H}]: 502.13103$, found: 502.13037 .

Tert-butyl(4-((5-chloro-4-((2-(methoxycarbamoyl)phenyl)amino)pyrimidin-2-yl) amino)benzyl)carbamate (2b). In an argon charged sealed tube, to the solution of $\mathbf{1 b}$ (337 mg, $1.08 \mathrm{mmol})$ in dioxane $(6 \mathrm{~mL})$ was added $\mathrm{Pd}_{2}(\mathrm{dba})_{3}(99 \mathrm{mg}, 10 \% \mathrm{mmol})$, XantPhos (128 mg, 20\% mmol) and $\mathrm{Cs}_{2} \mathrm{CO}_{3}(420 \mathrm{mg}, 1.29 \mathrm{mmol})$, followed the addition of tert-butyl (4-aminobenzyl)carbamate $(240 \mathrm{mg}, 1.08 \mathrm{mmol})$. The mixture was stirred at room temperature for 10 minutes, then stirred at $105^{\circ} \mathrm{C}$ for 24 hours. Subsequently, the solvent was concentrated and resulted residue was purified by silica gel chromatography (elution: $\mathrm{DCM} / \mathrm{MeOH}=100 / 1$ ) to give the titled compound as white solid (231 mg, 43\%). mp $216{ }^{\circ} \mathrm{C} .{ }^{1} \mathrm{H}$ NMR (500 MHz, DMSO-d 6 ) $\delta 11.98$ (s, 
1H), $10.89(\mathrm{~s}, 1 \mathrm{H}), 9.42(\mathrm{~s}, 1 \mathrm{H}), 8.68(\mathrm{~d}, J=8.4 \mathrm{~Hz}, 1 \mathrm{H}), 8.22(\mathrm{~s}, 1 \mathrm{H}), 7.66-7.60(\mathrm{~m}$, 1H), $7.57(\mathrm{~d}, J=8.2 \mathrm{~Hz}, 2 \mathrm{H}), 7.54-7.47(\mathrm{~m}, 1 \mathrm{H}), 7.30(\mathrm{t}, J=6.3 \mathrm{~Hz}, 1 \mathrm{H}), 7.17-7.10$ (m, 3H), $4.08(\mathrm{~d}, J=6.2 \mathrm{~Hz}, 2 \mathrm{H}), 3.74(\mathrm{~s}, 3 \mathrm{H}), 1.40(\mathrm{~s}, 9 \mathrm{H}) .{ }^{13} \mathrm{C}$ NMR $(126 \mathrm{MHz}$, DMSO- $\left.d_{6}\right) \delta 165.97,157.74,155.75,154.93,154.71,139.07,138.69,133.56,131.79$, $127.77,127.08,122.11,121.87,119.65,119.14,104.80,77.64,63.35,43.01,28.25$. HRMS (ESI) $m / z$ calcd. for $\mathrm{C}_{24} \mathrm{H}_{28} \mathrm{O}_{4} \mathrm{~N}_{6} \mathrm{Cl}[\mathrm{M}+\mathrm{H}]+: 499.18551$, found: 499.18489 .

Allyl (4-((4-chloro-5-(trifluoromethyl)pyrimidin-2-yl)amino)benzyl)carbamate (3). To a solution of 2,4-dichloro-5-(trifluromethyl)pyrimidine (200 $\mu \mathrm{L}, 1.48 \mathrm{mmol}$ ) in $10 \mathrm{~mL}$ of a $1: 1 \mathrm{mixture}$ of $\mathrm{t}-\mathrm{BuOH} / \mathrm{DCM}$ was added at $0{ }^{\circ} \mathrm{C}$ zinc chloride (403 mg, $2.96 \mathrm{mmol}$ ). After $1 \mathrm{~h}$, ally (4-aminobezyl)carbamate (305 mg, $1.48 \mathrm{mmol}$ ) was added followed by dropwise addition of triethylamine $(207 \mu \mathrm{L}, 1.48 \mathrm{mmol})$. After stirring for 6 hours, the mixture was diluted with DCM and washed with water and brine. The organic layer was dried over $\mathrm{MgSO}_{4}$. After filtration, the organic solution was concentrated in vacuo, and the residue was purified through silica gel chromatography (elution: $\mathrm{DCM} / \mathrm{MeOH}=150 / 1)$ to give titled compound as white solid (477 mg, 83\%). mp $154{ }^{\circ} \mathrm{C} .{ }^{\prime} \mathrm{H}$ NMR (500 MHz, Chloroform- $d$ ) $\delta 8.53(\mathrm{~s}, 1 \mathrm{H}), 7.65(\mathrm{~s}, 1 \mathrm{H}), 7.55(\mathrm{~d}, J$ $=8.3 \mathrm{~Hz}, 2 \mathrm{H}), 7.30(\mathrm{~d}, J=8.3 \mathrm{~Hz}, 2 \mathrm{H}), 5.99-5.89(\mathrm{~m}, 1 \mathrm{H}), 5.31(\mathrm{dq}, J=17.3,1.7 \mathrm{~Hz}$, 1H), $5.22(\mathrm{dp}, J=10.5,1.3 \mathrm{~Hz}, 1 \mathrm{H}), 5.09(\mathrm{~s}, 1 \mathrm{H}), 4.61(\mathrm{~d}, J=5.6 \mathrm{~Hz}, 2 \mathrm{H}), 4.37(\mathrm{~d}, J$ $=6.0 \mathrm{~Hz}, 2 \mathrm{H}) .{ }^{\mathrm{I}} \mathrm{C} \mathrm{NMR}\left(126 \mathrm{MHz}, \mathrm{CDCl}_{3}\right) \delta 160.63,157.49,156.45,136.89,134.91$, $132.95,128.48,123.78,122.90,121.62,120.85,117.92,65.91,44.75$. HRMS (ESI) $m / z$ calcd. for $\mathrm{C}_{10} \mathrm{H}_{15} \mathrm{O}_{2} \mathrm{~N}_{4} \mathrm{ClF}_{3}[\mathrm{M}+\mathrm{H}]+: 387.08356$, found: 387.08279 . 
Allyl(4-((4-((2-(methylcarbamoyl)phenyl)amino)-5-(trifluoromethyl)pyrimidin-2-

yl) amino)benzyl)carbamate (2g). To a solution 3 (380 $\mathrm{mg}, 0.98 \mathrm{mmol})$ in DMF was added 2-amino- $N$-methylbenzamide $(147 \mathrm{mg}, 0.98 \mathrm{mmol})$ followed by addition of $\mathrm{HCl}\left(250 \mu \mathrm{L}, 4 \mathrm{M}\right.$ in dioxane). The mixture was stirred at $90{ }^{\circ} \mathrm{C}$ for 7 hours. Then the solvent was removed in vacuo. To the residue DCM was added, the product was precipitate, through filtration the titled compound was obtained as white solid (286 mg, 58\%). mp $251{ }^{\circ} \mathrm{C} .{ }^{\prime} \mathrm{H}$ NMR (500 MHz, DMSO- $\left.d_{6}\right) \delta 11.35(\mathrm{~s}, 1 \mathrm{H}), 9.81(\mathrm{~s}, 1 \mathrm{H})$, $8.79(\mathrm{q}, J=4.6 \mathrm{~Hz}, 1 \mathrm{H}), 8.42(\mathrm{~s}, 1 \mathrm{H}), 7.76-7.72(\mathrm{~m}, 2 \mathrm{H}), 7.58(\mathrm{~d}, J=8.0 \mathrm{~Hz}, 2 \mathrm{H})$, $7.45(\mathrm{t}, J=8.0 \mathrm{~Hz}, 1 \mathrm{H}), 7.17-7.15(\mathrm{~m}, 3 \mathrm{H}), 5.96-5.89(\mathrm{~m}, 1 \mathrm{H}), 5.35-5.22(\mathrm{~m}, 1 \mathrm{H})$, $5.18(\mathrm{~d}, J=10.5 \mathrm{~Hz}, 1 \mathrm{H}), 4.50(\mathrm{~d}, J=5.0 \mathrm{~Hz}, 2 \mathrm{H}), 4.15(\mathrm{~d}, J=6.2 \mathrm{~Hz}, 2 \mathrm{H}), 2.78(\mathrm{~d}, J$ $=4.4 \mathrm{~Hz}, 3 \mathrm{H}) \cdot{ }^{\mathrm{i}} \mathrm{C}$ NMR $\left(126 \mathrm{MHz}, \mathrm{DMSO}-d_{6}\right) \delta 168.77,160.80,156.13,155.87$, $138.63,138.03,134.05,133.79,131.10,127.88,127.20,125.66,123.51,122.52$, 120.52, 116.87, 64.30, 43.42, 26.20. HRMS (ESI) $\mathrm{m} / \mathrm{z}$ calcd. for $\mathrm{C}_{24} \mathrm{H}_{24} \mathrm{O}_{3} \mathrm{~N}_{6} \mathrm{~F}_{3}[\mathrm{M}+\mathrm{H}]^{+}$ :501.18620, found: 501.18442.

General procedure for the synthesis of $\mathbf{4 a - g}$. To a solution of corresponding Alloc protected compounds (1.0 eq) in anhydrous THF or DMF, morpholine (10 eq) and $\mathrm{Pd}\left(\mathrm{PPh}_{3}\right)_{4}(0.1-0.5$ eq) were added under inert atmosphere. The mixture was stirred at room temperature without light for $3 \mathrm{~h}$. After the completion monitored with TLC, the solvent was concentrated under reduced pressure. The residue was purified through silica gel column chromatography to give the desired product. Method B: TFA and DCM (v/v=1/1) was added to the Boc protected compounds and the mixture was stirred at room temperature for 30 minutes. Then the solvent was concentrated in 
vacuo and diethyl ether was added to the residue, after the filtration to give the desired product.

2-((2-((4-(aminomethyl)phenyl)amino)-5-chloropyrimidin-4-yl)amino)- $N$-methylb enzamide (4a). White solid, yield 85\%, mp 205 C. 'H NMR (250 MHz, DMSO- $d 6) \delta$ $11.61(\mathrm{~s}, 1 \mathrm{H}), 9.43(\mathrm{~s}, 1 \mathrm{H}), 8.77(\mathrm{~d}, J=7.9 \mathrm{~Hz}, 2 \mathrm{H}), 8.22(\mathrm{~s}, 1 \mathrm{H}), 7.77(\mathrm{~d}, J=7.9 \mathrm{~Hz}$, 1H), $7.62(\mathrm{~d}, J=8.2 \mathrm{~Hz}, 2 \mathrm{H}), 7.52(\mathrm{t}, J=7.9 \mathrm{~Hz}, 1 \mathrm{H}), 7.26(\mathrm{~d}, \mathrm{~J}=8.2 \mathrm{~Hz}, 2 \mathrm{H}), 7.16$ $(\mathrm{t}, J=7.4 \mathrm{~Hz}, 1 \mathrm{H}), 3.73(\mathrm{~s}, 2 \mathrm{H}), 2.82(\mathrm{~d}, J=4.2 \mathrm{~Hz}, 3 \mathrm{H}) .{ }^{\mathrm{g}} \mathrm{C}$ NMR $(250 \mathrm{MHz}$, DMSO-d6) $\delta 168.87,157.74,154.94,154.57,139.28,138.56,136.46,131.43$, 127.94, 127.24, 121.88, 121.38, 120.70, 119.46, 104.89, 44.88, 26.28. HRMS (ESI) $m / z$ calcd. for $\mathrm{C}_{19} \mathrm{H}_{20} \mathrm{ClN}_{6} \mathrm{O} 383.1387$ found 383.1380 .

2-((2-((4-(aminomethyl)phenyl)amino)-5-chloropyrimidin-4-yl)amino)-N-methox ybenzamide trifluoroacetate (4b). White solid, 100\%, mp 240 'C. 'H NMR (250 MHz, Methanol- $\left.d_{4}\right) \delta 8.57(\mathrm{~d}, J=8.4 \mathrm{~Hz}, 2 \mathrm{H}), 8.17(\mathrm{~s}, 2 \mathrm{H}), 7.66(\mathrm{dd}, J=8.6,6.6 \mathrm{~Hz}, 6 \mathrm{H})$, 7.64-7.49 (m, 1H), $7.40(\mathrm{~d}, J=8.5 \mathrm{~Hz}, 4 \mathrm{H}), 7.32-7.17(\mathrm{~m}, 2 \mathrm{H}), 4.10(\mathrm{~s}, 4 \mathrm{H}), 3.82(\mathrm{~s}$, 6H). HRMS (ESI) $m / z$ calcd. for $\mathrm{C}_{19} \mathrm{H}_{20} \mathrm{ClN}_{6} \mathrm{O}_{2} 399.13308$, found: 399.13248 .

\section{$N-(3-(((2-((4-($ aminomethyl)phenyl)amino )-5-chloropyrimidin-4-yl)amino $)$ methyl $) p$} yridin-2-yl)-N-methylmethanesulfonamide (4c). White solid, yield 94\%, mp 124 ' C. 'H NMR $\left(250 \mathrm{MHz}\right.$, Methanol- $\left.d_{4}\right) \delta 8.43-8.41(\mathrm{~m}, 1 \mathrm{H}), 7.93-7.87(\mathrm{~m}, 1 \mathrm{H}), 7.81(\mathrm{dd}, J=$ 7.7, $1.9 \mathrm{~Hz}, 1 \mathrm{H}), 7.46-7.32(\mathrm{~m}, 3 \mathrm{H}), 7.14(\mathrm{~d}, J=8.6 \mathrm{~Hz}, 2 \mathrm{H}), 4.87(\mathrm{~s}, 2 \mathrm{H}), 3.74(\mathrm{~s}$, 2H), $3.22(\mathrm{~s}, 3 \mathrm{H}), 3.13(\mathrm{~s}, 3 \mathrm{H}) .{ }^{\mathrm{a}} \mathrm{C}$ NMR (126 MHz, MeOD) $\delta$ 159.57, 154.04, $153.89,148.77,140.81,139.18,135.88,135.11,129.07,125.35,120.72,116.57$, 
105.67, 45.80, 41.35, 37.93, 36.39. HRMS (ESI) $m / z$ calcd. for $\mathrm{C}_{19} \mathrm{H}_{23} \mathrm{O}_{2} \mathrm{~N}_{7} \mathrm{ClS}[\mathrm{M}+\mathrm{H}]+$ 448.13170, found: 448.13054 .

$N-(2-(((2-((4-($ aminomethyl $)$ phenyl $)$ amino $)-5-c h l o r o p y r i m i d i n-4-y l)$ amino $) m e t h y l$ )phenyl)-N-methylmethanesulfonamide (4d). White solid, yield 84\%, mp 218 C. 'H NMR $\left(500 \mathrm{MHz}, \mathrm{DMSO}-d_{6}\right) \delta 9.06(\mathrm{~s}, 1 \mathrm{H}), 7.98(\mathrm{~s}, 1 \mathrm{H}), 7.55(\mathrm{dd}, J=7.0,2.0 \mathrm{~Hz}$, $1 \mathrm{H}), 7.47(\mathrm{t}, J=6.0 \mathrm{~Hz}, 1 \mathrm{H}), 7.43(\mathrm{~d}, J=8.2 \mathrm{~Hz}, 2 \mathrm{H}), 7.38-7.30(\mathrm{~m}, 3 \mathrm{H}), 7.06(\mathrm{~d}, J=$ $8.2 \mathrm{~Hz}, 2 \mathrm{H}), 4.78(\mathrm{~d}, J=32.3 \mathrm{~Hz}, 2 \mathrm{H}), 3.59(\mathrm{~s}, 2 \mathrm{H}), 3.19(\mathrm{~s}, 3 \mathrm{H}), 3.11(\mathrm{~s}, 3 \mathrm{H}) \cdot{ }^{13} \mathrm{C}$ NMR (126 MHz, DMSO- $\left.d_{6}\right) \delta 158.06,157.60,153.19,139.61,139.25,138.81$, $136.53,128.34,127.88,127.81,127.04,127.02,118.43,103.33,45.18,40.06,38.64$, 35.98. HRMS (ESI) $\mathrm{m} / \mathrm{z}$ calcd. for $\mathrm{C}_{20} \mathrm{H}_{24} \mathrm{O}_{2} \mathrm{~N}_{6} \mathrm{ClS}[\mathrm{M}+\mathrm{H}]+$ : 447.13645, found: 447.13549 .

N-(3-(((2-((4-(aminomethyl)phenyl)amino)-5-chloropyrimidin-4-yl)amino)methyl )phenyl)-N-methylmethanesulfonamide (4e). White solid, yield $81 \%, \mathrm{mp} 176^{\circ} \mathrm{C} .{ }^{\prime} \mathrm{H}$ NMR (500 MHz, DMSO- $\left.d_{6}\right) \delta 9.11(\mathrm{~s}, 1 \mathrm{H}), 7.97(\mathrm{~s}, 1 \mathrm{H}), 7.81(\mathrm{t}, J=6.2 \mathrm{~Hz}, 1 \mathrm{H}), 7.55$ $-7.51(\mathrm{~m}, 2 \mathrm{H}), 7.42(\mathrm{~m}, 1 \mathrm{H}), 7.38(\mathrm{t}, J=7.7 \mathrm{~Hz}, 1 \mathrm{H}), 7.30-7.26(\mathrm{~m}, 2 \mathrm{H}), 7.17-7.12$ $(\mathrm{m}, 2 \mathrm{H}), 4.64(\mathrm{~d}, J=6.1 \mathrm{~Hz}, 2 \mathrm{H}), 3.64(\mathrm{~s}, 2 \mathrm{H}), 3.17(\mathrm{~s}, 3 \mathrm{H}), 2.88(\mathrm{~s}, 3 \mathrm{H}) \cdot{ }^{\mathrm{r}} \mathrm{C} \mathrm{NMR}$ (126 MHz, DMSO) $\delta 157.95,157.32,153.22,141.57,140.76,138.86,136.36$, $128.93,127.01,125.66,125.14,124.55,118.50,103.26,45.08,43.29,37.76,34.93$. HRMS (ESI) $m / z$ calcd. for $\mathrm{C}_{20} \mathrm{H}_{24} \mathrm{O}_{2} \mathrm{~N}_{6} \mathrm{ClS}[\mathrm{M}+\mathrm{H}]+: 447.13645$, found: 447.13558 .

$N^{2-}$ (4-(aminomethyl)phenyl)-5-chloro- $N^{4}-(3-($ methylsulfonyl)benzyl)pyrimidine-2, 4-diamine (4f). White solid, yield 86.5\%, mp $216{ }^{\circ} \mathrm{C} .{ }^{\prime} \mathrm{H}$ NMR (500 MHz, DMSO- $\left.d_{6}\right)$ $\delta 9.15(\mathrm{~s}, 1 \mathrm{H}), 7.98(\mathrm{~s}, 1 \mathrm{H}), 7.95-7.91(\mathrm{~m}, 2 \mathrm{H}), 7.81(\mathrm{~d}, J=7.7 \mathrm{~Hz}, 1 \mathrm{H}), 7.69(\mathrm{~d}, J=$ 
$7.7 \mathrm{~Hz}, 1 \mathrm{H}), 7.62(\mathrm{t}, J=7.7 \mathrm{~Hz}, 1 \mathrm{H}), 7.48(\mathrm{~d}, J=8.1 \mathrm{~Hz}, 2 \mathrm{H}), 7.14(\mathrm{~d}, J=8.2 \mathrm{~Hz}$, 2H), $4.71(\mathrm{~d}, J=6.0 \mathrm{~Hz}, 2 \mathrm{H}), 3.65(\mathrm{~s}, 2 \mathrm{H}), 3.14(\mathrm{~s}, 3 \mathrm{H}) \cdot{ }^{1 \mathrm{C}} \mathrm{NMR}(126 \mathrm{MHz}$, DMSO- $\left.d_{6}\right) \delta 157.94,157.31,153.36,141.37,140.81,138.98,135.39,131.96,129.43$, 127.21, 125.32, 125.15, 118.49, 103.31, 44.78, 43.46, 43.28. HRMS (ESI) $\mathrm{m} / \mathrm{z}$ calcd. for $\mathrm{C}_{19} \mathrm{H}_{21} \mathrm{O}_{2} \mathrm{~N}_{5} \mathrm{ClS}[\mathrm{M}+\mathrm{H}]+:$ 418.10990, found: 418.10920 .

2-((2-((4-(aminomethyl)phenyl)amino)-5-(trifluoromethyl)pyrimidin-4-yl)amino)$N$-methylbenzamide (4g). White solid, yield 68\%, mp $180{ }^{\circ} \mathrm{C} .{ }^{\prime} \mathrm{H}$ NMR (500 MHz, Methanol- $\left.d_{4}\right) \delta 8.37(\mathrm{~d}, J=8.6 \mathrm{~Hz}, 1 \mathrm{H}), 8.30(\mathrm{~d}, J=1.1 \mathrm{~Hz}, 1 \mathrm{H}), 7.63(\mathrm{dd}, J=7.9$, 1.6 Hz, 1H), 7.56-7.51 (m, 2H), $7.45(\mathrm{ddd}, J=8.6,7.4,1.7 \mathrm{~Hz}, 1 \mathrm{H}), 7.25(\mathrm{~d}, J=8.5$ $\mathrm{Hz}, 2 \mathrm{H}), 7.18(\mathrm{td}, J=7.6,1.2 \mathrm{~Hz}, 1 \mathrm{H}), 3.80(\mathrm{~d}, J=3.0 \mathrm{~Hz}, 2 \mathrm{H}), 2.89(\mathrm{~d}, J=1.3 \mathrm{~Hz}$, 3H). ${ }^{13} \mathrm{C}$ NMR (126 MHz, MeOD) $\delta 171.57,162.26,158.15,156.54,139.47,139.32$, $132.46,129.03,128.76,126.91,125.14,125.01,124.77,124.54,122.38,68.43,26.87$. HRMS (ESI) $m / z$ calcd. for $\mathrm{C}_{20} \mathrm{H}_{2} \mathrm{ON}_{6} \mathrm{~F}_{3}[\mathrm{M}+\mathrm{H}] *: 417.16507$, found: 417.16470.

General procedure for the synthesis of 5a-g. To a solution of appropriate amine (1.0 eq) in dry DMF were added tert-butyl (2-((2-methoxy-3,4-dioxocyclobut-1-en-1yl)amino)ethyl)carbamate (1.0 eq) and DIPEA (1.0 eq). The mixture was stirred at $75^{\circ} \mathrm{C}$ for overnight. After removal of solvent, the crude product was purified by flash silica gel chromatography to give the desired product as solid.

Tert-butyl(2-((2-)(4-((5-chloro-4-((2-(methylcarbamoyl)phenyl)amino)pyrimidin2-yl)amino)benzyl)amino)-3,4-dioxocyclobut-1-en-1-yl)amino)ethyl)carbamate (5a). White solid, yield 77\%, mp $226{ }^{\circ} \mathrm{C} .{ }^{1} \mathrm{H}$ NMR $\left(250 \mathrm{MHz}, \mathrm{DMSO}-d_{6}\right) \delta 11.62(\mathrm{~s}, 1 \mathrm{H})$, $9.51(\mathrm{~s}, 1 \mathrm{H}), 8.74(\mathrm{~d}, J=8.3 \mathrm{~Hz}, 2 \mathrm{H}), 8.23(\mathrm{~s}, 1 \mathrm{H}), 7.77$ (d, $J=7.8 \mathrm{~Hz}, 1 \mathrm{H}), 7.66$ (d, $J$ 
$=8.2 \mathrm{~Hz}, 2 \mathrm{H}), 7.47(\mathrm{t}, J=7.9 \mathrm{~Hz}, 1 \mathrm{H}), 7.26(\mathrm{~d}, J=8.2 \mathrm{~Hz}, 2 \mathrm{H}), 7.14(\mathrm{t}, J=7.5 \mathrm{~Hz}$, 1H), $6.91(\mathrm{~s}, 1 \mathrm{H}), 4.66(\mathrm{~d}, J=5.9 \mathrm{~Hz}, 2 \mathrm{H}), 3.52(\mathrm{~s}, 2 \mathrm{H}), 3.10(\mathrm{~d}, J=6.1 \mathrm{~Hz}, 2 \mathrm{H}), 2.82$ $(\mathrm{d}, J=4.3 \mathrm{~Hz}, 3 \mathrm{H}), 1.36(\mathrm{~s}, 9 \mathrm{H}) .{ }^{13} \mathrm{C}$ NMR $\left(250 \mathrm{MHz}, \mathrm{DMSO}-d_{\mathrm{6}}\right) \delta$ 182.6, 182.4, 168.8 (2C), 162.2, 157.6, 155.7, 154.9, 154.5, 139.5, 139.2, 132.0, 131.3, 127.9, $127.8,121.9,121.4,120.7,119.8,105.1,77.8,46.5,43.2,41.1,28.1(3 \mathrm{C}), 26.2$. HRMS (ESI+): $m / z$ calcd. for $\mathrm{C}_{30} \mathrm{H}_{33} \mathrm{ClN}_{8} \mathrm{O}_{5}$ 621.2341, found 621.2308.

Tert-butyl(2-((2-((4-((5-chloro-4-((2-(methoxycarbamoyl)phenyl)amino)pyrimidi n-2-yl)amino)benzyl)amino)-3,4-dioxocyclobut-1-en-1-yl)amino)ethyl)carbamate

(5b). White solid, yield 42\%, mp $206{ }^{\circ} \mathrm{C} .{ }^{1} \mathrm{H}$ NMR (500 MHz, DMSO- $\left.d_{6}\right) \delta 11.97$ (s, 1H), $10.91(\mathrm{~s}, 1 \mathrm{H}), 9.49(\mathrm{~s}, 1 \mathrm{H}), 8.67(\mathrm{~d}, J=8.3 \mathrm{~Hz}, 1 \mathrm{H}), 8.23(\mathrm{~s}, 1 \mathrm{H}), 7.63(\mathrm{t}, J=8.4$ $\mathrm{Hz}, 3 \mathrm{H}), 7.53-7.47(\mathrm{~m}, 1 \mathrm{H}), 7.29-7.22(\mathrm{~m}, 2 \mathrm{H}), 7.14(\mathrm{td}, J=7.6,1.2 \mathrm{~Hz}, 1 \mathrm{H}), 6.88(\mathrm{t}$, $J=5.7 \mathrm{~Hz}, 1 \mathrm{H}), 4.71-4.57(\mathrm{~m}, 2 \mathrm{H}), 3.73(\mathrm{~s}, 3 \mathrm{H}), 3.51(\mathrm{~s}, 2 \mathrm{H}), 3.09(\mathrm{q}, J=5.9 \mathrm{~Hz}$, 2H), 1.35 (s, 9H). ${ }^{13} \mathrm{C}$ NMR (126 MHz, DMSO- $\left.d_{6}\right) \delta 182.64,182.45,168.09,167.38$, $165.94,157.64,155.70,154.94,154.67,139.44,139.02,132.11,131.81,127.81$, $127.76,122.20,121.85,119.79,119.16,105.02,77.78,63.34,46.48,43.22,41.12$, 28.16. HRMS (ESI) $m / z$ calcd. for $\mathrm{C}_{30} \mathrm{H}_{34} \mathrm{O}_{6} \mathrm{~N}_{8} \mathrm{Cl}[\mathrm{M}+\mathrm{H}]+: 637.22843$ found: 637.22760 . Tert-butyl(2-((2-)(4-((5-chloro-4-(((2-(N-methylmethylsulfonamido)pyridin-3-yl) methyl)amino)pyrimidin-2-yl)amino)benzyl)amino)-3,4-dioxocyclobut-1-en-1-yl)amin o)ethyl)carbamate (5c). Beige solid, yield 58\%, mp $209{ }^{\circ} \mathrm{C} . ~ ' \mathrm{H}$ NMR (500 MHz, DMSO- $\left.d_{6}\right) \delta 9.18(\mathrm{~s}, 1 \mathrm{H}), 8.43(\mathrm{dd}, J=4.7,1.9 \mathrm{~Hz}, 1 \mathrm{H}), 8.01(\mathrm{~s}, 1 \mathrm{H}), 7.73-7.68(\mathrm{~m}$, $1 \mathrm{H}), 7.66(\mathrm{t}, J=6.0 \mathrm{~Hz}, 1 \mathrm{H}), 7.45-7.39(\mathrm{~m}, 3 \mathrm{H}), 7.04(\mathrm{~d}, J=8.1 \mathrm{~Hz}, 2 \mathrm{H}), 6.87(\mathrm{~d}, J=$ $5.8 \mathrm{~Hz}, 1 \mathrm{H}), 4.76(\mathrm{~d}, J=5.9 \mathrm{~Hz}, 2 \mathrm{H}), 4.63-4.52(\mathrm{~m}, 2 \mathrm{H}), 3.51(\mathrm{~s}, 2 \mathrm{H}), 3.15(\mathrm{~s}, 6 \mathrm{H})$, 
$3.09(\mathrm{q}, J=6.0 \mathrm{~Hz}, 2 \mathrm{H}), 1.35(\mathrm{~s}, 9 \mathrm{H}) .{ }^{\mathrm{i}} \mathrm{C}$ NMR $\left(126 \mathrm{MHz}, \mathrm{DMSO}-d_{6}\right) \delta$ 182.60, $182.44,168.00,167.35,157.91,157.66,155.70,153.32,152.18,147.26,139.86$, $137.11,133.91,131.18,127.69,124.03,118.46,103.66,77.79,46.42,43.19,41.12$, 37.15, 35.98, 28.16. HRMS (ESI) $m / z$ calcd. for $\mathrm{C}_{30} \mathrm{H}_{37} \mathrm{O}_{6} \mathrm{~N}_{9} \mathrm{ClS}[\mathrm{M}+\mathrm{H}] * 686.22705$ found: 686.22590 .

Tert-butyl (2-((2-((4-((5-chloro-4-((2-(N-methylmethylsulfonamido)benzyl)amino) pyrimidin-2-yl)amino)benzyl)amino)-3,4-dioxocyclobut-1-en-1-yl)amino)ethyl)carba mate (5d). White solid, yield 86\%, mp $237{ }^{\circ} \mathrm{C} .{ }^{\prime} \mathrm{H}$ NMR (500 MHz, DMSO- $\left.d_{\sigma}\right) \delta 9.19$ $(\mathrm{s}, 1 \mathrm{H}), 8.00(\mathrm{~s}, 1 \mathrm{H}), 7.53(\mathrm{t}, J=4.5 \mathrm{~Hz}, 2 \mathrm{H}), 7.48(\mathrm{~d}, J=8.1 \mathrm{~Hz}, 2 \mathrm{H}), 7.37-7.32(\mathrm{~m}$, 2H), $7.30(\mathrm{~d}, J=5.4 \mathrm{~Hz}, 1 \mathrm{H}), 7.06(\mathrm{~d}, J=8.2 \mathrm{~Hz}, 2 \mathrm{H}), 6.89(\mathrm{~d}, J=5.9 \mathrm{~Hz}, 1 \mathrm{H})$, 4.85-4.72 (m, 2H), 4.65-4.51 (m, 2H), $3.52(\mathrm{~s}, 2 \mathrm{H}), 3.17(\mathrm{~s}, 3 \mathrm{H}), 3.11-3.08(\mathrm{~m}, 5 \mathrm{H})$, $1.36(\mathrm{~s}, 9 \mathrm{H}) .{ }^{13} \mathrm{C}$ NMR $\left(126 \mathrm{MHz}, \mathrm{DMSO}-d_{6}\right) \delta 182.61,182.44,168.04,167.37$, $157.95,157.67,155.71,153.21,139.97,139.56,139.19,131.10,128.36,127.86$, $127.79,127.67,127.00,118.48,103.61,77.80,46.45,43.22,41.13,38.58,35.93$, 28.17. HRMS (ESI) $m / z$ calcd. for $\mathrm{C}_{31} \mathrm{H}_{38} \mathrm{O}_{6} \mathrm{~N}_{8} \mathrm{ClS}[\mathrm{M}+\mathrm{H}] *$ : 685.23181, found: 685.23068

Tert-butyl (2-((2-((4-((5-chloro-4-((3-(N-methylmethylsulfonamido)benzyl)amino) pyrimidin-2-yl)amino)benzyl)amino)-3,4-dioxocyclobut-1-en-1-yl)amino)ethyl)carba mate (5e). White solid, yield 82\%, mp $234{ }^{\circ} \mathrm{C} .{ }^{\mathrm{H}} \mathrm{NMR}\left(500 \mathrm{MHz}, \mathrm{DMSO}-d_{6}\right) \delta 9.22$ $(\mathrm{s}, 1 \mathrm{H}), 7.98(\mathrm{~s}, 1 \mathrm{H}), 7.83(\mathrm{t}, J=6.1 \mathrm{~Hz}, 1 \mathrm{H}), 7.59(\mathrm{~d}, J=8.4 \mathrm{~Hz}, 2 \mathrm{H}), 7.42(\mathrm{t}, J=1.9$ $\mathrm{Hz}, 1 \mathrm{H}), 7.37(\mathrm{t}, J=7.8 \mathrm{~Hz}, 1 \mathrm{H}), 7.30-7.24(\mathrm{~m}, 2 \mathrm{H}), 7.16(\mathrm{~d}, J=8.3 \mathrm{~Hz}, 2 \mathrm{H}), 6.88(\mathrm{t}$, $J=5.7 \mathrm{~Hz}, 1 \mathrm{H}), 4.63(\mathrm{~m}, 4 \mathrm{H}), 3.52(\mathrm{~s}, 2 \mathrm{H}), 3.32(\mathrm{~s}, 2 \mathrm{H}), 3.18(\mathrm{~s}, 3 \mathrm{H}), 3.10(\mathrm{q}, J=6.0$ 
$\mathrm{Hz}, 2 \mathrm{H}), 2.88(\mathrm{~s}, 3 \mathrm{H}), 1.37(\mathrm{~s}, 9 \mathrm{H}) .{ }^{\mathrm{i}} \mathrm{C} \mathrm{NMR}\left(126 \mathrm{MHz}, \mathrm{DMSO}-d_{6}\right) \delta 182.61,182.40$, $168.03,167.33,157.84,157.36,155.70,153.20,141.61,140.70,139.98,131.14$, $128.91,127.75,125.67,125.05,124.53,118.66,103.59,77.78,46.48,43.21,41.12$, 37.76, 34.89, 28.16. HRMS (ESI) $m / z$ calcd. for $\mathrm{C}_{31} \mathrm{H}_{38} \mathrm{O}_{6} \mathrm{~N}_{8} \mathrm{ClS}[\mathrm{M}+\mathrm{H}]+$ : 685.23181, found: 685.23092 .

Tert-butyl(2-((2-((4-((5-chloro-4-((3-(methylsulfonyl)benzyl)amino)pyrimidin-2-y l)amino)benzyl)amino)-3,4-dioxocyclobut-1-en-1-yl)amino)ethyl)carbamate (5f). White solid, yield 68\%, mp $186{ }^{\circ} \mathrm{C} .{ }^{\mathrm{H}} \mathrm{NMR}\left(500 \mathrm{MHz}, \mathrm{DMSO}-d_{6}\right) \delta 9.23(\mathrm{~s}, 1 \mathrm{H})$, $8.00(\mathrm{~s}, 1 \mathrm{H}), 7.97-7.89(\mathrm{~m}, 2 \mathrm{H}), 7.80(\mathrm{~d}, J=7.6 \mathrm{~Hz}, 1 \mathrm{H}), 7.69(\mathrm{~d}, J=7.7 \mathrm{~Hz}, 1 \mathrm{H})$, $7.61(\mathrm{t}, J=7.7 \mathrm{~Hz}, 1 \mathrm{H}), 7.55(\mathrm{~d}, J=8.2 \mathrm{~Hz}, 2 \mathrm{H}), 7.15(\mathrm{~d}, J=8.2 \mathrm{~Hz}, 2 \mathrm{H}), 6.88(\mathrm{t}, J=$ $5.7 \mathrm{~Hz}, 1 \mathrm{H}), 4.72(\mathrm{~d}, J=6.1 \mathrm{~Hz}, 2 \mathrm{H}), 4.61(\mathrm{~d}, J=5.9 \mathrm{~Hz}, 2 \mathrm{H}), 3.52(\mathrm{~s}, 2 \mathrm{H}), 3.14(\mathrm{~s}$, $3 \mathrm{H}), 3.10(\mathrm{q}, J=6.0 \mathrm{~Hz}, 2 \mathrm{H}), 1.36(\mathrm{~s}, 9 \mathrm{H}) .{ }^{\mathrm{r}} \mathrm{C}$ NMR $\left(126 \mathrm{MHz}, \mathrm{DMSO}-d_{\sigma}\right) \delta 182.61$, $182.42,168.05,167.36,157.86,157.35,155.70,153.32,141.32,140.84,139.88$, $132.08,131.22,129.38,127.73,125.33,125.10,118.69,103.59,77.78,46.48,43.45$, 43.28, 41.12, 28.16. HRMS (ESI) $m / z$ calcd. for $\mathrm{C}_{30} \mathrm{H}_{33} \mathrm{O}_{6} \mathrm{~N}_{7} \mathrm{ClS}[\mathrm{M}+\mathrm{H}]+$ : 656.20526, found: 656.20439 .

Tert-butyl (2-((2-((4-((4-((2-(methylcarbamoyl)phenyl)amino)-5-(trifluoromethyl) pyrimidin-2-yl)amino)benzyl)amino)-3,4-dioxocyclobut-1-en-1-yl)amino)ethyl)carba mate (5g). White solid, yield 89\%, mp $258{ }^{\circ} \mathrm{C}$. 'H NMR (500 MHz, DMSO- $\left.d_{\sigma}\right) \delta 11.34$ $(\mathrm{s}, 1 \mathrm{H}), 9.84(\mathrm{~s}, 1 \mathrm{H}), 8.71(\mathrm{q}, J=4.6 \mathrm{~Hz}, 1 \mathrm{H}), 8.43(\mathrm{~s}, 1 \mathrm{H}), 7.72(\mathrm{dd}, J=7.9,1.6 \mathrm{~Hz}$, $1 \mathrm{H}), 7.63(\mathrm{~d}, J=8.1 \mathrm{~Hz}, 2 \mathrm{H}), 7.43(\mathrm{t}, J=7.9 \mathrm{~Hz}, 1 \mathrm{H}), 7.36(\mathrm{q}, J=5.0 \mathrm{~Hz}, 1 \mathrm{H}), 7.24$ $(\mathrm{d}, J=8.1 \mathrm{~Hz}, 2 \mathrm{H}), 7.15(\mathrm{t}, J=7.6 \mathrm{~Hz}, 1 \mathrm{H}), 6.88(\mathrm{t}, J=5.7 \mathrm{~Hz}, 1 \mathrm{H}), 4.66(\mathrm{~s}, 2 \mathrm{H})$, 
3.58-3.45 (m, 2H), $3.10(\mathrm{q}, J=6.0 \mathrm{~Hz}, 2 \mathrm{H}), 2.79(\mathrm{~d}, J=4.5 \mathrm{~Hz}, 3 \mathrm{H}), 1.35(\mathrm{~s}, 9 \mathrm{H}),{ }^{\mathrm{a}} \mathrm{C}$ NMR (126 MHz, DMSO- $\left.d_{\sigma}\right) \delta 182.65,182.50,168.74,168.15,167.40,160.75$, $156.12,155.90,155.73,138.61,133.12,132.49,131.07,127.81,125.62,124.43$, $123.47,123.07,122.59,122.11,120.71,77.81,46.44,43.24,41.13,28.16,26.20$. HRMS (ESI) $m / z$ calcd. for $\mathrm{C}_{31} \mathrm{H}_{34} \mathrm{O}_{5} \mathrm{~N}_{8} \mathrm{~F}_{3}[\mathrm{M}+\mathrm{H}]+:$ 655.26043, found: 655.26227.

General procedure for the synthesis of 6a-g. TFA and DCM $(v / v=1 / 1)$ was added to the Boc protected compounds and the mixture was stirred at room temperature for 30 minutes. Then the solvent was concentrated in vacuo and diethyl ether was added to the residue, after the filtration to give the desired product, which was directly used for the next step without further purification.

\section{2-((2-((4-(((2-((2-aminoethyl)amino)-3,4-dioxocyclobut-1-en-1-yl)amino)methyl)}

phenyl)amino)-5-chloropyrimidin-4-yl)amino)- $N$-methylbenzamide trifluoroacetate salt (6a). Solid, yield 100\%. ${ }^{1} \mathrm{H}$ NMR (250 MHz, DMSO-d $) \delta 11.67(\mathrm{~s}, 1 \mathrm{H}), 9.55$ (s, 1H), 8.75 (d, $J=10.6 \mathrm{~Hz}, 2 \mathrm{H}), 8.24(\mathrm{~s}, 1 \mathrm{H}), 7.87(\mathrm{~s}, 2 \mathrm{H}), 7.77$ (d, $J=7.8 \mathrm{~Hz}, 1 \mathrm{H})$, $7.66(\mathrm{~d}, J=8.3 \mathrm{~Hz}, 3 \mathrm{H}), 7.48(\mathrm{t}, J=7.8 \mathrm{~Hz}, 1 \mathrm{H}), 7.26(\mathrm{~d}, J=8.1 \mathrm{~Hz}, 2 \mathrm{H}), 7.14(\mathrm{t}, J=$ $7.6 \mathrm{~Hz}, 1 \mathrm{H}), 3.72(\mathrm{~d}, J=6.9 \mathrm{~Hz}, 2 \mathrm{H}), 3.03(\mathrm{~d}, J=6.1 \mathrm{~Hz}, 2 \mathrm{H}), 2.82(\mathrm{~d}, J=4.4 \mathrm{~Hz}$, 3H). ${ }^{13} \mathrm{C}$ NMR (250 MHz, DMSO- $\left.d_{\sigma}\right) \quad \delta \quad 182.8,182.3,168.7,168.2,155.7$, $155.6,155.4,150.8,138.5,138.2,133.5,131.5,128.0,127.9,122.8,121.8,121.2$ 120.9, 105.3, 46.4, 40.8, 39.3,26.3. HRMS (ESI): $\mathrm{m} / \mathrm{z}$ calcd. for $\mathrm{C}_{25} \mathrm{H}_{26} \mathrm{ClN}_{8} \mathrm{O}_{3}[\mathrm{M}+\mathrm{H}]:$ : 521.1816, found 521.1803.

\section{2-((2-((4-(((2-)(2-aminoethyl)amino)-3,4-dioxocyclobut-1-en-1-yl)amino $)$ methyl $)$}

phenyl)amino)-5-chloropyrimidin-4-yl)amino)-N-methoxybenzamide trifluoroacetate 
salt (6b). Solid, yield 100\%. 'H NMR (500 MHz, DMSO- $\left.d_{6}\right) \delta 12.02(\mathrm{~s}, 1 \mathrm{H}), 10.99$ (s, 1H), $9.66(\mathrm{~s}, 1 \mathrm{H}), 8.63(\mathrm{~d}, J=8.3 \mathrm{~Hz}, 1 \mathrm{H}), 8.26(\mathrm{~s}, 1 \mathrm{H}), 8.15(\mathrm{~s}, 1 \mathrm{H}), 7.92(\mathrm{~s}, 3 \mathrm{H})$, $7.77(\mathrm{~s}, 1 \mathrm{H}), 7.63(\mathrm{t}, J=7.7 \mathrm{~Hz}, 3 \mathrm{H}), 7.49(\mathrm{t}, J=8.0 \mathrm{~Hz}, 1 \mathrm{H}), 7.26(\mathrm{~d}, J=8.2 \mathrm{~Hz}$, 2H), $7.15(\mathrm{t}, J=7.6 \mathrm{~Hz}, 1 \mathrm{H}), 4.67(\mathrm{~s}, 2 \mathrm{H}), 3.73(\mathrm{~d}, J=10.5 \mathrm{~Hz}, 5 \mathrm{H}), 3.03(\mathrm{q}, J=6.0$ $\mathrm{Hz}, 2 \mathrm{H}) .{ }^{\mathrm{I}} \mathrm{C} \mathrm{NMR}\left(126 \mathrm{MHz}, \mathrm{DMSO}-d_{\sigma}\right) \delta 182.95,182.51,168.02,165.93,157.05$, $155.24,153.46,139.14,138.81,132.57,131.85,127.94,127.86,122.57,122.10$, 120.19, 119.47, 117.04, 114.72, 105.18, 63.37, 46.55, 40.99. HRMS (ESI) $m / z$ calcd. for $\mathrm{C}_{25} \mathrm{H}_{26} \mathrm{ClN}_{8} \mathrm{O}_{4}$ 537.17601, found 537.17561.

$N-(3-(((2-)(4-(((2-((2-a m i n o e t h y l)$ amino $)-3,4-d i o x o c y c l o b u t-1-e n-1-y l)$ amino $)$ met hyl)phenyl)amino)-5-chloropyrimidin-4-yl)amino)methyl)pyridin-2-yl)-N-methylmeth anesulfonamide trifluoroacetate salt (6c). Pale solid, yield 100\%. 'H NMR (500 MHz, Methanol- $\left.d_{4}\right) \delta 8.44(\mathrm{dd}, J=4.7,1.8 \mathrm{~Hz}, 1 \mathrm{H}), 8.00(\mathrm{~s}, 1 \mathrm{H}), 7.73(\mathrm{dd}, J=7.8,1.8 \mathrm{~Hz}$, 1H), $7.36(\mathrm{dd}, J=7.8,5.0 \mathrm{~Hz}, 3 \mathrm{H}), 7.26(\mathrm{~d}, J=8.3 \mathrm{~Hz}, 2 \mathrm{H}), 4.90(\mathrm{~s}, 2 \mathrm{H}), 4.74(\mathrm{~s}$, $2 \mathrm{H}), 3.88(\mathrm{t}, J=6.0 \mathrm{~Hz}, 2 \mathrm{H}), 3.21(\mathrm{t}, J=5.9 \mathrm{~Hz}, 2 \mathrm{H}), 3.12(\mathrm{~s}, 3 \mathrm{H}), 3.10(\mathrm{~s}, 3 \mathrm{H}) \cdot{ }^{\mathrm{B}} \mathrm{C}$ NMR (126 MHz, MeOD) $\delta$ 184.22, 184.03, 169.85, 169.25, 160.76, 154.07, 153.98, $149.27,143.58,139.07,138.00,134.05,129.60,125.40,123.25,119.23,106.58$ 44.64, 42.48, 42.43, 41.49, 37.89, 36.27. HRMS (ESI) $m / z$ calcd. for $\mathrm{C}_{25} \mathrm{H}_{29} \mathrm{O}_{4} \mathrm{~N}_{9} \mathrm{ClS}$ $[\mathrm{M}+\mathrm{H}]+: 586.17463$, found: 586.17391.

$N-(2-(((2-((4-(((2-)(2-a m i n o e t h y l) a m i n o)-3,4-d i o x o c y c l o b u t-1-e n-1-y l) a m i n o) m e t$ hyl)phenyl)amino)-5-chloropyrimidin-4-yl)amino)methyl)phenyl)- $N$-methylmethanesu Ifonamide trifluoroacetate salt (6d). White solid, yield 100\%. 'H NMR (500 MHz, Methanol- $\left.d_{f}\right) \delta 8.00(\mathrm{~s}, 1 \mathrm{H}), 7.52(\mathrm{~d}, J=7.8 \mathrm{~Hz}, 1 \mathrm{H}), 7.42(\mathrm{td}, J=7.6,1.8 \mathrm{~Hz}, 1 \mathrm{H})$, 
7.39-7.30 (m, 4H), $7.26(\mathrm{~d}, J=8.2 \mathrm{~Hz}, 2 \mathrm{H}), 4.96(\mathrm{~d}, J=15.9 \mathrm{~Hz}, 2 \mathrm{H}), 4.74(\mathrm{~d}, J=8.7$ $\mathrm{Hz}, 2 \mathrm{H}), 3.87(\mathrm{t}, J=6.0 \mathrm{~Hz}, 2 \mathrm{H}), 3.20(\mathrm{t}, J=6.0 \mathrm{~Hz}, 2 \mathrm{H}), 3.13(\mathrm{~s}, 3 \mathrm{H}), 3.04(\mathrm{~s}, 3 \mathrm{H})$. ${ }^{13} \mathrm{C}$ NMR (126 MHz, MeOD) $\delta 184.21,184.01,169.84,169.29,160.67,153.18$, $142.07,141.36,138.65,137.66,130.04,129.96,129.72,129.61,128.26,123.45$, 119.19, 106.63, 48.25, 43.04, 42.48, 41.48, 39.37, 35.90. HRMS (ESI) $\mathrm{m} / z$ calcd. for $\mathrm{C}_{26} \mathrm{H}_{30} \mathrm{O}_{4} \mathrm{~N}_{8} \mathrm{ClS}[\mathrm{M}+\mathrm{H}]+: 585.17938$, found: 585.17836 .

$N-(3-(((2-((4-)((2-((2-a m i n o e t h y l) a m i n o)-3,4-d i o x o c y c l o b u t-1-e n-1-y l) a m i n o) m e t$ hyl)phenyl)amino)-5-chloropyrimidin-4-yl)amino)methyl)phenyl)-N-methylmethanesu lfonamide trifluoroacetate salt (6e). Pale solid, yield 100\%. 'H NMR (500 MHz, Methanol- $\left.d_{4}\right) \delta 7.90(\mathrm{~s}, 1 \mathrm{H}), 7.32-7.20(\mathrm{~m}, 8 \mathrm{H}), 7.13(\mathrm{dt}, J=7.6,1.4 \mathrm{~Hz}, 1 \mathrm{H}), 4.68(\mathrm{~s}$, 2H), $4.62(\mathrm{~s}, 2 \mathrm{H}), 3.77(\mathrm{~s}, 2 \mathrm{H}), 3.70-3.66(\mathrm{~m}, 1 \mathrm{H}), 3.12(\mathrm{~d}, J=5.4 \mathrm{~Hz}, 6 \mathrm{H}), 2.68(\mathrm{~s}$, 3H). HRMS (ESI) $m / z$ calcd. for $\mathrm{C}_{26} \mathrm{H}_{30} \mathrm{O}_{4} \mathrm{~N}_{8} \mathrm{ClS}[\mathrm{M}+\mathrm{H}]+: 585.17938$, found: 585.17886 . 3-((2-aminoethyl)amino)-4-((4-((5-chloro-4-((3-(methylsulfonyl)benzyl)amino)py rimidin-2-yl)amino)benzyl)amino)cyclobut-3-ene-1,2-dione trifluoroacetate salt (6f). Pale solid, yield 100\%. ${ }^{1} \mathrm{H}$ NMR (250 MHz, Methanol- $\left.d_{4}\right) \delta$ 7.91-7.81 (m, 2H), 7.64-7.57 (m, 2H), 7.41-7.33 (m, 3H), 4.84-4.73 (m, 4H), $3.88(\mathrm{t}, J=6.0 \mathrm{~Hz}, 2 \mathrm{H})$, $3.20(\mathrm{t}, J=6.0 \mathrm{~Hz}, 2 \mathrm{H}), 3.02(\mathrm{~s}, 3 \mathrm{H})$. HRMS (ESI) $m / z$ calcd. for $\mathrm{C}_{25} \mathrm{H}_{27} \mathrm{O}_{4} \mathrm{~N}_{7} \mathrm{ClS}$ $[\mathrm{M}+\mathrm{H}]^{+}:$556.15283, found: 556.15204 .

\section{2-((2-((4-(((2-((2-aminoethyl)amino)-3,4-dioxocyclobut-1-en-1-yl)amino)methyl)}

phenyl)amino)-5-(trifluoromethyl)pyrimidin-4-yl)amino)-N-methylbenzamide trifluoroacetate salt (6g). White solid, yield 100\%. 'H NMR (500 MHz, DMSO- $\left.d_{\sigma}\right) \delta$ $11.35(\mathrm{~s}, 1 \mathrm{H}), 9.86(\mathrm{~s}, 1 \mathrm{H}), 8.73(\mathrm{q}, J=4.5 \mathrm{~Hz}, 1 \mathrm{H}), 8.43(\mathrm{~s}, 1 \mathrm{H}), 8.13(\mathrm{~d}, J=7.2 \mathrm{~Hz}$, 
1H), $7.90(\mathrm{~s}, 3 \mathrm{H}), 7.72(\mathrm{dd}, J=7.9,1.6 \mathrm{~Hz}, 2 \mathrm{H}), 7.63(\mathrm{~d}, J=8.1 \mathrm{~Hz}, 2 \mathrm{H}), 7.44(\mathrm{t}, J=$ $8.0 \mathrm{~Hz}, 1 \mathrm{H}), 7.24(\mathrm{~d}, J=8.2 \mathrm{~Hz}, 2 \mathrm{H}), 7.15(\mathrm{td}, J=7.6,1.2 \mathrm{~Hz}, 1 \mathrm{H}), 4.66(\mathrm{~s}, 2 \mathrm{H}), 3.72$ $(\mathrm{q}, J=6.2 \mathrm{~Hz}, 2 \mathrm{H}), 3.02(\mathrm{p}, J=5.9 \mathrm{~Hz}, 2 \mathrm{H}), 2.78(\mathrm{~d}, J=4.6 \mathrm{~Hz}, 3 \mathrm{H})$.

General procedure for the synthesis of compounds $7 \mathbf{a}_{2}-\mathrm{g}$. To a ice cooled solution of appropriate amine trifluorocetate salt in dry DMF was added $\mathrm{Et}_{3} \mathrm{~N}$ (or DIPEA) (5 eq) and appropriate chloride $(1.5 \mathrm{eq})$ at $0{ }^{\circ} \mathrm{C}$. The mixture was stirred at room temperature for $12 \mathrm{~h}$. The solvent was removed in vacuoand the crude product was purified by column chromatography.

2-((5-chloro-2-((4-)((2-((2-(2-chloroacetamido)ethyl)amino)-3,4-dioxocyclobut-1 -en-1-yl)amino)methyl)phenyl)amino)pyrimidin-4-yl)amino)-N-methylbenzamide (7a $\mathbf{a}_{2}$. White solid, yield $32 \%, \mathrm{mp}>260{ }^{\circ} \mathrm{C} .{ }^{1} \mathrm{H}$ NMR $\left(500 \mathrm{MHz}, \mathrm{DMSO}-d_{6}\right) \delta 11.61$ (s, 1H), $9.51(\mathrm{~s}, 1 \mathrm{H}), 8.87-8.66(\mathrm{~m}, 2 \mathrm{H}), 8.38(\mathrm{t}, J=5.8 \mathrm{~Hz}, 1 \mathrm{H}), 8.22(\mathrm{~s}, 1 \mathrm{H}), 7.75$ $(\mathrm{dd}, J=7.9,1.6 \mathrm{~Hz}, 1 \mathrm{H}), 7.65(\mathrm{~d}, J=8.2 \mathrm{~Hz}, 2 \mathrm{H}), 7.46(\mathrm{t}, J=7.9 \mathrm{~Hz}, 1 \mathrm{H}), 7.24(\mathrm{dd}, J$ $=8.6,3.4 \mathrm{~Hz}, 2 \mathrm{H}), 7.13(\mathrm{t}, J=7.5 \mathrm{~Hz}, 1 \mathrm{H}), 4.65(\mathrm{~s}, 2 \mathrm{H}), 4.03(\mathrm{~s}, 2 \mathrm{H}), 3.57(\mathrm{~s}, 2 \mathrm{H})$, $3.28(\mathrm{p}, J=6.0,5.5 \mathrm{~Hz}, 3 \mathrm{H}), 2.81(\mathrm{~d}, J=4.5 \mathrm{~Hz}, 3 \mathrm{H}) .{ }^{13} \mathrm{C}$ NMR (126 MHz, DMSO- $\left.d_{\sigma}\right) \delta 182.72,182.47,168.91,168.13,167.47,166.35,157.68,155.00,154.60$, $139.53,139.27,131.45,127.99,127.89,122.00,121.47,120.78,119.86,105.21$, 46.53, 42.69, 42.60, 40.29, 26.34. HRMS (ESI) $m / z$ calcd. for $[\mathrm{M}+\mathrm{H}]+\mathrm{C}_{27} \mathrm{H}_{27} \mathrm{C}_{22} \mathrm{~N}_{8} \mathrm{O}_{4}$ 597.15323, found 597.15395.

2-((2-((4-(((2-((2-acrylamidoethyl)amino)-3,4-dioxocyclobut-1-en-1-yl)amino)me thyl)phenyl)amino)-5-chloropyrimidin-4-yl)amino)-N-methoxybenzamide (7b). White solid, yield $28 \%, \mathrm{mp} 234{ }^{\circ} \mathrm{C} .{ }^{\prime} \mathrm{H}$ NMR $\left(500 \mathrm{MHz}, \mathrm{DMSO}-d_{\sigma}\right) \delta 8.62(\mathrm{~d}, J=8.3 \mathrm{~Hz}$, 
$1 \mathrm{H}), 8.20(\mathrm{~s}, 1 \mathrm{H}), 7.60(\mathrm{t}, J=7.0 \mathrm{~Hz}, 3 \mathrm{H}), 7.48(\mathrm{t}, J=8.0 \mathrm{~Hz}, 1 \mathrm{H}), 7.23(\mathrm{~d}, J=8.1$ $\mathrm{Hz}, 2 \mathrm{H}), 7.13(\mathrm{t}, J=7.6 \mathrm{~Hz}, 1 \mathrm{H}), 6.23-6.04(\mathrm{~m}, 2 \mathrm{H}), 5.59(\mathrm{dd}, J=9.9,2.2 \mathrm{~Hz}, 1 \mathrm{H})$, $4.64(\mathrm{~s}, 2 \mathrm{H}), 3.72(\mathrm{~s}, 3 \mathrm{H}), 3.59(\mathrm{~s}, 2 \mathrm{H}), 3.30(\mathrm{t}, J=6.1 \mathrm{~Hz}, 2 \mathrm{H}) .{ }^{\mathrm{r}} \mathrm{C}$ NMR $(126 \mathrm{MHz}$, DMSO- $\left.d_{6}\right) \delta 182.77,182.59,168.24,167.60,166.18,165.49,157.82,155.16,154.95$, $139.52,138.98,132.45,132.15,131.54,128.09,128.03,125.88,122.66,122.19$, 120.11, 119.48, 105.25, 63.67, 46.62, 42.96, 42.03. HRMS (ESI) $\mathrm{m} / z$ calcd. for $[\mathrm{M}+\mathrm{H}]+\mathrm{C}_{28} \mathrm{H}_{20} \mathrm{ClN}_{8} \mathrm{O}_{5}, 589.17092$, found: 589.17023 .

N-(2-((2-((4-((5-chloro-4-((2-(N-methylmethylsulfonamido)benzyl)amino)pyrimid in-2-yl)amino)benzyl)amino)-3,4-dioxocyclobut-1-en-1-yl)amino)ethyl)acrylamide

(7c). White solid, yield 56\%, mp $219{ }^{\circ} \mathrm{C} .{ }^{\prime} \mathrm{H}$ NMR (500 MHz, DMSO- $\left.d_{6}\right) \delta 9.22(\mathrm{~s}$, $1 \mathrm{H}), 8.26(\mathrm{t}, J=5.6 \mathrm{~Hz}, 1 \mathrm{H}), 8.01(\mathrm{~s}, 1 \mathrm{H}), 7.58(\mathrm{t}, J=6.0 \mathrm{~Hz}, 1 \mathrm{H}), 7.55-7.51(\mathrm{~m}$, $1 \mathrm{H}), 7.46(\mathrm{~d}, J=8.1 \mathrm{~Hz}, 2 \mathrm{H}), 7.35(\mathrm{dt}, J=5.5,2.0 \mathrm{~Hz}, 2 \mathrm{H}), 7.30(\mathrm{~d}, J=5.5 \mathrm{~Hz}, 1 \mathrm{H})$, $7.06(\mathrm{~d}, J=8.1 \mathrm{~Hz}, 2 \mathrm{H}), 6.19(\mathrm{dd}, J=17.1,10.1 \mathrm{~Hz}, 1 \mathrm{H}), 6.08(\mathrm{dd}, J=17.1,2.3 \mathrm{~Hz}$, 1H), $5.59(\mathrm{dd}, J=10.0,2.3 \mathrm{~Hz}, 1 \mathrm{H}), 4.78(\mathrm{t}, J=7.3 \mathrm{~Hz}, 2 \mathrm{H}), 4.58(\mathrm{~s}, 2 \mathrm{H}), 3.73-3.53$ $(\mathrm{m}, 2 \mathrm{H}), 3.31(\mathrm{q}, J=5.8 \mathrm{~Hz}, 2 \mathrm{H}), 3.16(\mathrm{~s}, 3 \mathrm{H}), 3.11(\mathrm{~s}, 3 \mathrm{H}) \cdot{ }^{\mathrm{i}} \mathrm{C}$ NMR (126 MHz, DMSO- $\left.d_{\sigma}\right) \delta 182.61,182.45,167.94,167.42,164.98,157.70,152.82,139.81,139.55$, $139.11,131.54,131.25,128.36,127.85,127.79,127.64,127.00,125.26,118.56$, 103.63, 46.42, 42.79, 40.27, 38.56, 35.92. HRMS (ESI) $\mathrm{m} / z$ calcd. for $\mathrm{C}_{29} \mathrm{H}_{32} \mathrm{O}_{5} \mathrm{~N}_{8} \mathrm{ClS}$ $[\mathrm{M}+\mathrm{H}]+:$ 639.18994, found: 639.18772 .

N-(2-((2-)(4-((5-chloro-4-((3-(N-methylmethylsulfonamido)benzyl)amino)pyrimid in-2-yl)amino)benzyl)amino)-3,4-dioxocyclobut-1-en-1-yl)amino)ethyl)acrylamide (7d). White solid, yield 61\%, mp $153{ }^{\circ} \mathrm{C} .{ }^{\prime} \mathrm{H}$ NMR (500 MHz, DMSO- $\left.d_{6}\right) \delta 9.22(\mathrm{~s}$, 
$1 \mathrm{H}), 8.26(\mathrm{t}, J=6.0 \mathrm{~Hz}, 1 \mathrm{H}), 7.98(\mathrm{~s}, 1 \mathrm{H}), 7.84(\mathrm{t}, J=6.1 \mathrm{~Hz}, 1 \mathrm{H}), 7.59(\mathrm{~d}, J=8.2$ $\mathrm{Hz}, 2 \mathrm{H}), 7.41(\mathrm{~s}, 1 \mathrm{H}), 7.36(\mathrm{t}, J=7.8 \mathrm{~Hz}, 1 \mathrm{H}), 7.30-7.25(\mathrm{~m}, 2 \mathrm{H}), 7.16(\mathrm{~d}, J=8.2 \mathrm{~Hz}$, 2H), $6.20(\mathrm{dd}, J=17.1,10.1 \mathrm{~Hz}, 1 \mathrm{H}), 6.09(\mathrm{dd}, J=17.1,2.3 \mathrm{~Hz}, 1 \mathrm{H}), 5.59(\mathrm{dd}, J=$ 10.0, $2.3 \mathrm{~Hz}, 1 \mathrm{H}), 4.63(\mathrm{~m}, 4 \mathrm{H}), 3.59(\mathrm{~s}, 2 \mathrm{H}), 3.32$ (d, J = 6.2 Hz, 2H), $3.17(\mathrm{~s}, 3 \mathrm{H})$, $2.88(\mathrm{~s}, 3 \mathrm{H}) .{ }^{13} \mathrm{C}$ NMR $\left(126 \mathrm{MHz}, \mathrm{DMSO}-d_{6}\right) \delta 182.65,182.46,168.00,167.44$, $165.05,157.85,157.40,153.19,141.64,140.73,139.98,131.56,131.23,128.95$, $127.79,125.71,125.31,125.08,124.56,118.73,103.64,46.52,43.34,42.83,37.79$, 34.91. HRMS (ESI) $\mathrm{m} / z$ calcd. for $\mathrm{C}_{29} \mathrm{H}_{32} \mathrm{O}_{5} \mathrm{~N}_{8} \mathrm{ClS}[\mathrm{M}+\mathrm{H}]+$ : 639.18994, found: 639.18925.

$\mathrm{N}-(2-((2-((4-((5-c h l o r o-4-((3-($ methylsulfonyl)benzyl)amino)pyrimidin-2-yl)amino )benzyl)amino)-3,4-dioxocyclobut-1-en-1-yl)amino)ethyl)acrylamide (7e). White solid, yield 65\%, mp $198^{\circ} \mathrm{C}$. 'H NMR (500 MHz, DMSO- $\left.d_{\sigma}\right) \delta 9.23(\mathrm{~s}, 1 \mathrm{H}), 8.25$ (t, $J$ $=5.9 \mathrm{~Hz}, 1 \mathrm{H}), 7.99(\mathrm{~s}, 1 \mathrm{H}), 7.94(\mathrm{t}, J=6.2 \mathrm{~Hz}, 1 \mathrm{H}), 7.91(\mathrm{~s}, 1 \mathrm{H}), 7.79(\mathrm{~d}, J=7.7 \mathrm{~Hz}$, 1H), $7.68(\mathrm{~d}, J=7.7 \mathrm{~Hz}, 1 \mathrm{H}), 7.60(\mathrm{t}, J=7.7 \mathrm{~Hz}, 1 \mathrm{H}), 7.54(\mathrm{~d}, J=8.1 \mathrm{~Hz}, 2 \mathrm{H}), 7.14$ $(\mathrm{d}, J=8.1 \mathrm{~Hz}, 2 \mathrm{H}), 6.24-6.03(\mathrm{~m}, 2 \mathrm{H}), 5.58(\mathrm{dd}, J=10.0,2.3 \mathrm{~Hz}, 1 \mathrm{H}), 4.71(\mathrm{~d}, J=$ $6.1 \mathrm{~Hz}, 2 \mathrm{H}), 4.66-4.54(\mathrm{~m}, 2 \mathrm{H}), 3.58(\mathrm{~s}, 2 \mathrm{H}), 3.31(\mathrm{~d}, J=6.0 \mathrm{~Hz}, 2 \mathrm{H}), 3.13(\mathrm{~s}, 3 \mathrm{H})$. ${ }^{13} \mathrm{C}$ NMR $\left(126 \mathrm{MHz}, \mathrm{DMSO}-d_{6}\right) \delta 182.63,182.45,167.99,167.43,165.00,157.83$, $157.36,153.27,141.32,140.84,139.87,132.08,131.55,131.27,129.38,127.74$, $125.33,125.26,125.10,118.72,103.60,46.48,43.44,43.29,42.80,40.11$. HRMS (ESI) $m / z$ calcd. for $\mathrm{C}_{28} \mathrm{H}_{29} \mathrm{O}_{5} \mathrm{~N}_{7} \mathrm{ClS}[\mathrm{M}+\mathrm{H}]+: 610.16449$, found: 610.16272 .

N-(2-((2-((4-((5-chloro-4-(((2-(N-methylmethylsulfonamido)pyridin-3-yl)methyl)a mino)pyrimidin-2-yl)amino)benzyl)amino)-3,4-dioxocyclobut-1-en-1-yl)amino)ethyl)a 
crylamide (7f). White solid, yield $50 \%, \mathrm{mp} 179{ }^{\circ} \mathrm{C} .{ }^{\prime} \mathrm{H}$ NMR $\left(500 \mathrm{MHz}, \mathrm{DMSO}-d_{\sigma}\right) \delta$ $9.24(\mathrm{~s}, 1 \mathrm{H}), 8.43(\mathrm{~d}, J=4.7 \mathrm{~Hz}, 1 \mathrm{H}), 8.26(\mathrm{t}, J=5.8 \mathrm{~Hz}, 1 \mathrm{H}), 8.02(\mathrm{~s}, 1 \mathrm{H}), 7.76-7.69$ $(\mathrm{m}, 2 \mathrm{H}), 7.41(\mathrm{dd}, J=12.6,7.9 \mathrm{~Hz}, 3 \mathrm{H}), 7.04(\mathrm{~d}, J=8.2 \mathrm{~Hz}, 2 \mathrm{H}), 6.19(\mathrm{dd}, J=17.1$, $10.1 \mathrm{~Hz}, 1 \mathrm{H}), 6.08(\mathrm{dd}, J=17.2,2.3 \mathrm{~Hz}, 1 \mathrm{H}), 5.58(\mathrm{dd}, J=10.0,2.3 \mathrm{~Hz}, 1 \mathrm{H}), 4.76(\mathrm{~d}$, $J=5.9 \mathrm{~Hz}, 2 \mathrm{H}), 4.64-4.48(\mathrm{~m}, 2 \mathrm{H}), 3.58(\mathrm{~s}, 2 \mathrm{H}), 3.31(\mathrm{q}, J=6.6,6.2 \mathrm{~Hz}, 2 \mathrm{H}), 3.14$ (s, 6H). ${ }^{13} \mathrm{C}$ NMR (126 MHz, DMSO- $\left.d_{\sigma}\right) \delta 182.61,182.46,167.93,167.41,165.00$, $157.74,157.54,152.68,152.18,147.30,139.65,137.13,133.81,131.54,127.72$, 125.27, 124.04, 118.64, 103.72, 46.40, 42.79, 40.11, 37.15, 35.98. HRMS (ESI) $\mathrm{m} / \mathrm{z}$ calcd. for $\mathrm{C}_{28} \mathrm{H}_{29} \mathrm{O}_{5} \mathrm{~N}_{9} \mathrm{ClS}[\mathrm{M}-\mathrm{H}]+: 638.16954$, found: 638.16895 .

2-((2-((4-(((2-((2-acrylamidoethyl)amino)-3,4-dioxocyclobut-1-en-1-yl)amino)me thyl)phenyl)amino)-5-(trifluoromethyl)pyrimidin-4-yl)amino)- $N$-methylbenzamide (7g). White solid, yield 60\%, mp $179{ }^{\circ} \mathrm{C} .{ }^{1} \mathrm{H}$ NMR (500 MHz, DMSO- $\left.d_{6}\right) \delta 11.33$ (s, 1H), $9.85(\mathrm{~s}, 1 \mathrm{H}), 8.79-8.65(\mathrm{~m}, 1 \mathrm{H}), 8.43(\mathrm{~s}, 2 \mathrm{H}), 8.27(\mathrm{~s}, 1 \mathrm{H}), 7.72(\mathrm{~d}, J=7.9 \mathrm{~Hz}$, 1H), $7.63(\mathrm{~d}, J=8.1 \mathrm{~Hz}, 2 \mathrm{H}), 7.43(\mathrm{t}, J=7.9 \mathrm{~Hz}, 1 \mathrm{H}), 7.24(\mathrm{~d}, J=8.1 \mathrm{~Hz}, 2 \mathrm{H}), 7.15$ $(\mathrm{t}, J=7.6 \mathrm{~Hz}, 1 \mathrm{H}), 6.27-6.00(\mathrm{~m}, 2 \mathrm{H}), 5.58(\mathrm{~d}, J=10.2 \mathrm{~Hz}, 1 \mathrm{H}), 4.66(\mathrm{~s}, 2 \mathrm{H}), 3.59(\mathrm{~s}$, 2H), $2.79(\mathrm{~d}, J=4.6 \mathrm{~Hz}, 3 \mathrm{H}) .{ }^{1} \mathrm{C}$ NMR (126 MHz, DMSO- $\left.d_{\sigma}\right) \delta 182.66,182.52$, $168.74,168.06,167.47,165.02,160.76,156.12,155.90,138.58,133.15,131.54$, $131.06,127.80,125.62,125.27,123.47,123.09,122.58,122.08,120.74,46.44$, 42.81, 39.78, 26.20. HRMS (ESI) $\mathrm{m} / \mathrm{z}$ calcd. for $\mathrm{C}_{29} \mathrm{H}_{28} \mathrm{O}_{4} \mathrm{~N}_{8} \mathrm{~F}_{3}[\mathrm{M}+\mathrm{H}] *$ : 609.21856, found: 609.21967 .

2-((5-chloro-2-((4-)((2-((2-(2-cyanoacetamido)ethyl)amino)-3,4-dioxocyclobut-1en-1-yl)amino)methyl)phenyl)amino)pyrimidin-4-yl)amino)-N-methylbenzamide 
To an ice cold solution of $\mathbf{6 a}(500 \mathrm{mg}, 0.67 \mathrm{mmol})$ in dry DMF (3 mL) was added DIPEA (700 $\mu \mathrm{L}, 4.01 \mathrm{mmol})$, EDCI (257 mg, $1.34 \mathrm{mmol})$, HOBt (181 mg, 1.34 $\mathrm{mmol})$, followed by addition of cyanoacetic acid $(114 \mathrm{mg}, 1.34 \mathrm{mmol})$. The mixture was continue stirred at $0{ }^{\circ} \mathrm{C}$ for 30 mins, then stirred at room temperature overnight. The solvent was removed in vacuo, then the residue was purified though silica gel chromatography (elution: $\mathrm{DCM} / \mathrm{MeOH}=20 / 1 \sim 10 / 1$ ) to give the final product as yellow solid (293 mg, 74\%). mp $258{ }^{\circ} \mathrm{C},{ }^{\prime} \mathrm{H}$ NMR (500 MHz, DMSO- $\left.d_{6}\right) \delta 11.61(\mathrm{~s}$, 1H), $9.49(\mathrm{~s}, 1 \mathrm{H}), 8.74(\mathrm{t}, J=5.9 \mathrm{~Hz}, 2 \mathrm{H}), 8.40(\mathrm{t}, J=5.7 \mathrm{~Hz}, 1 \mathrm{H}), 8.22(\mathrm{~s}, 1 \mathrm{H}), 7.76$ $(\mathrm{d}, J=7.8 \mathrm{~Hz}, 1 \mathrm{H}), 7.66(\mathrm{~d}, J=8.2 \mathrm{~Hz}, 2 \mathrm{H}), 7.47(\mathrm{t}, J=7.9 \mathrm{~Hz}, 1 \mathrm{H}), 7.26(\mathrm{~d}, J=8.1$ $\mathrm{Hz}, 2 \mathrm{H}), 7.14(\mathrm{t}, J=7.6 \mathrm{~Hz}, 1 \mathrm{H}), 4.66(\mathrm{~s}, 2 \mathrm{H}), 3.58(\mathrm{~s}, 2 \mathrm{H}), 3.58-3.52(\mathrm{~m}, 2 \mathrm{H}), 3.26$ $(\mathrm{q}, J=6.0 \mathrm{~Hz}, 2 \mathrm{H}), 2.82(\mathrm{~d}, J=4.4 \mathrm{~Hz}, 3 \mathrm{H}) \cdot{ }^{\mathrm{B}} \mathrm{C}$ NMR $\left(126 \mathrm{MHz}, \mathrm{DMSO}-d_{\sigma}\right) \delta$ $182.71,182.46,168.87,168.02,167.49,162.50,157.66,154.97,154.58,139.51$, $139.25,132.03,131.40,127.95,127.88,121.95,121.44,120.77,119.85,116.02$, 105.18, 46.52, 42.63, 40.36, 26.30, 25.31. HRMS (ESI) $\mathrm{m} / z$ calcd. for $\mathrm{C}_{28} \mathrm{H}_{27} \mathrm{O}_{4} \mathrm{~N}_{9} \mathrm{Cl}$ $[\mathrm{M}+\mathrm{H}]+588.18745$, found: 588.18890 .

General Procedure for the Synthesis of Compound 9a-c. To a solution of 8 (1 eq) in a mixture of DMF and acetic acid (1:1) were added piperidine (1.5 eq) and appropriate aldehyde (1.5 eq). The solution was heated to $100{ }^{\circ} \mathrm{C}$ and stirred for 2 hours. After cooled to room temperature, the solvent was removed in vacuo. Subsequently, the residue was purified through silica gel chromatography to give desired product as solid. 
(E)-2-((5-chloro-2-((4-)((2-)((2-(2-cyanopent-2-enamido)ethyl)amino)-3,4-dioxoc yclobut-1-en-1-yl)amino)methyl)phenyl)amino)pyrimidin-4-yl)amino)-N-methylbenza mide (9a). Beige solid, yield 34\%, mp $194{ }^{\circ} \mathrm{C}$. 'H NMR (500 MHz, DMSO- $\left.d_{6}\right) \delta 11.61$ (s, 1H), $9.49(\mathrm{~s}, 1 \mathrm{H}), 8.80-8.68(\mathrm{~m}, 2 \mathrm{H}), 8.46(\mathrm{~s}, 1 \mathrm{H}), 8.22(\mathrm{~s}, 1 \mathrm{H}), 7.76(\mathrm{~d}, J=7.9$ $\mathrm{Hz}, 1 \mathrm{H}), 7.65(\mathrm{~d}, J=8.1 \mathrm{~Hz}, 2 \mathrm{H}), 7.47(\mathrm{t}, J=7.9 \mathrm{~Hz}, 1 \mathrm{H}), 7.40(\mathrm{t}, J=7.7 \mathrm{~Hz}, 1 \mathrm{H})$, $7.25(\mathrm{~d}, J=8.1 \mathrm{~Hz}, 2 \mathrm{H}), 7.13(\mathrm{t}, J=7.6 \mathrm{~Hz}, 1 \mathrm{H}), 4.66(\mathrm{~s}, 2 \mathrm{H}), 3.61(\mathrm{~s}, 2 \mathrm{H}), 3.38-3.34$ $(\mathrm{m}, 2 \mathrm{H}), 2.82(\mathrm{~d}, J=4.5 \mathrm{~Hz}, 3 \mathrm{H}), 2.42(\mathrm{q}, J=7.5 \mathrm{~Hz}, 2 \mathrm{H}), 1.24(\mathrm{~s}, 1 \mathrm{H}), 1.06(\mathrm{t}, J=$ $7.5 \mathrm{~Hz}, 2 \mathrm{H}) .{ }^{13} \mathrm{C}$ NMR $\left(126 \mathrm{MHz}, \mathrm{DMSO}-d_{\sigma}\right) \delta 182.69,182.45,168.86,168.14$, $167.50,160.68,159.42,157.66,154.97,154.57,139.50,139.24,132.13,131.38$, $127.93,127.81,121.93,121.42,120.76,119.83,114.55,111.26,105.16,46.50,42.57$, 40.67, 26.28, 24.77, 12.15. HRMS (ESI) $\mathrm{m} / \mathrm{z}$ calcd. for $\mathrm{C}_{31} \mathrm{H}_{31} \mathrm{O}_{4} \mathrm{~N}_{9} \mathrm{Cl}[\mathrm{M}+\mathrm{H}]+$ 628.21875, found: 628.22015 .

(E)-2-((5-chloro-2-((4-(((2-((2-(2-cyano-4-methylpent-2-enamido)ethyl)amino)-3, 4-dioxocyclobut-1-en-1-yl)amino)methyl)phenyl)amino)pyrimidin-4-yl)amino)-N-met hylbenzamide (9b). Beige solid, yield 63\%, mp 236 'C. 'H NMR (500 MHz, DMSO- $\left.d_{6}\right) \delta 11.60(\mathrm{~s}, 1 \mathrm{H}), 9.47(\mathrm{~s}, 1 \mathrm{H}), 8.87-8.65(\mathrm{~m}, 2 \mathrm{H}), 8.46(\mathrm{t}, J=5.8 \mathrm{~Hz}, 1 \mathrm{H})$, $8.21(\mathrm{~s}, 1 \mathrm{H}), 7.75(\mathrm{~d}, J=7.9 \mathrm{~Hz}, 1 \mathrm{H}), 7.65(\mathrm{~d}, J=8.1 \mathrm{~Hz}, 2 \mathrm{H}), 7.46(\mathrm{t}, J=7.8 \mathrm{~Hz}$, $1 \mathrm{H}), 7.25(\mathrm{~d}, J=7.9 \mathrm{~Hz}, 2 \mathrm{H}), 7.13(\mathrm{t}, J=7.5 \mathrm{~Hz}, 1 \mathrm{H}), 4.66(\mathrm{~s}, 2 \mathrm{H}), 3.60(\mathrm{~s}, 2 \mathrm{H})$, $3.37-3.33(\mathrm{~m}, 2 \mathrm{H}), 2.81(\mathrm{~d}, J=4.5 \mathrm{~Hz}, 3 \mathrm{H}), 2.76(\mathrm{dd}, J=8.2,4.8 \mathrm{~Hz}, 1 \mathrm{H}), 1.68(\mathrm{~d}, J$ $=19.8 \mathrm{~Hz}, 1 \mathrm{H}), 1.06(\mathrm{~d}, J=6.6 \mathrm{~Hz}, 5 \mathrm{H}) .{ }^{1} \mathrm{C}$ NMR $\left(126 \mathrm{MHz}, \mathrm{DMSO}-d_{\sigma}\right) \delta 182.69$, $182.48,168.87,168.10,167.52,163.39,160.78,157.66,154.97,154.57,139.51$, $139.25,132.10,131.39,127.94,127.85,127.81,121.94,121.43,120.76,119.83$, 
114.50, 109.75, 105.18, 46.51, 42.60, 40.70, 31.22, 26.29, 21.07. HRMS (ESI) $\mathrm{m} / \mathrm{z}$ calcd. for $\mathrm{C}_{32} \mathrm{H}_{33} \mathrm{O}_{4} \mathrm{~N}_{9} \mathrm{Cl}[\mathrm{M}+\mathrm{H}]+: 642.23440$, found: 642.23553 .

(E)-2-((5-chloro-2-((4-(((2-)(2-(2-cyano-3-cyclopropylacrylamido)ethyl)amino $)-3$ ,4-dioxocyclobut-1-en-1-yl)amino)methyl)phenyl)amino)pyrimidin-4-yl)amino)-N-met hylbenzamide (9c). Beige solid, yield 63\%, mp 248 ${ }^{\circ} \mathrm{C}$. 'H NMR (500 MHz, DMSO- $\left.d_{\sigma}\right)$ $\delta 11.62(\mathrm{~s}, 1 \mathrm{H}), 9.49(\mathrm{~s}, 1 \mathrm{H}), 8.75(\mathrm{q}, J=4.0 \mathrm{~Hz}, 2 \mathrm{H}), 8.28(\mathrm{t}, J=5.7 \mathrm{~Hz}, 1 \mathrm{H}), 8.23$ $(\mathrm{s}, 1 \mathrm{H}), 7.77(\mathrm{dd}, J=8.0,1.6 \mathrm{~Hz}, 1 \mathrm{H}), 7.66(\mathrm{~d}, J=8.1 \mathrm{~Hz}, 2 \mathrm{H}), 7.47(\mathrm{t}, J=7.7 \mathrm{~Hz}$, 1H), $7.26(\mathrm{~d}, J=8.3 \mathrm{~Hz}, 2 \mathrm{H}), 7.14(\mathrm{t}, J=7.5 \mathrm{~Hz}, 1 \mathrm{H}), 6.90(\mathrm{~d}, J=11.1 \mathrm{~Hz}, 1 \mathrm{H}), 4.67$ (s, 2H), 3.68-3.52 (m, 2H), $3.35(\mathrm{~d}, J=6.0 \mathrm{~Hz}, 2 \mathrm{H}), 2.82(\mathrm{~d}, J=4.5 \mathrm{~Hz}, 3 \mathrm{H}), 1.89$ $(\mathrm{dtt}, J=11.9,7.9,4.2 \mathrm{~Hz}, 1 \mathrm{H}), 1.22(\mathrm{dt}, J=7.7,3.7 \mathrm{~Hz}, 2 \mathrm{H}), 0.97-0.86(\mathrm{~m}, 2 \mathrm{H}) .{ }^{\mathrm{i}} \mathrm{C}$ NMR (126 MHz, DMSO- $\left.d_{6}\right) \delta 182.68,182.47,168.87,168.12,167.51,163.97$, $160.78,157.66,154.97,154.57,139.50,139.24,132.11,131.38,127.94,127.81$, $121.93,121.43,120.75,119.83,115.56,107.48,105.17,46.50,42.63,40.63,26.28$, 15.37, 10.37. HRMS (ESI) $\mathrm{m} / z$ calcd. for $\mathrm{C}_{32} \mathrm{H}_{31} \mathrm{O}_{4} \mathrm{~N}_{9} \mathrm{Cl}[\mathrm{M}+\mathrm{H}]+: 640.21875$, found: 640.21960.

In Vitro Kinase Assay, Kinetic characterization and reversibility of thiol addition. $\mathrm{IC}_{50}$ determinations for $\mathrm{FAK}$ was carried out using an $\mathrm{ADP}-\mathrm{Glo}^{\mathrm{m}}$ kinase assay from Promega Corporation according to the manufacturer's instructions and using Graph-Pad Prism (GraphPad Software, San Diego, CA, USA). In this assay, FAK, FAK substrate and ATP were set to $5 \mathrm{ng}, 0.5 \mu \mathrm{g}$ and $8 \mu \mathrm{M}$ respectively in each reaction well, which was mixed with the different concentrations of tested compounds in Kinase reaction buffer (40 mM Tris, $20 \mathrm{mM} \mathrm{MgCl} 2,0.1 \mathrm{mg} / \mathrm{mL}$ BSA, $2 \mathrm{mM} \mathrm{MnCl}$, 
$2 \mu \mathrm{M}$ DTT). After completion of the reaction for $1 \mathrm{~h}$, the kinase reaction was stopped by the addition of ADP-Glo ${ }^{\mathrm{TM}}$ Reagent $(5 \mu \mathrm{L})$ and incubated at room temperature for 40 min. Finally the luminescence signal was detected with an Enspire plate reader after addition of Kinase Detection Reagent $(10 \mu \mathrm{L})$ and incubation at room temperature for 15-20 minutes.

For kinetic characterization $\left(\mathrm{Ki}, k_{\text {mat }}\right)$, the selected compounds were preincubated with FAK during different periods of time (2-60 $\mathrm{min})$. The duration of the incubation and stop reaction were kept constant as described above. $\mathrm{IC}_{50}$ values were plotted versus incubation time, and data were calculated with XLfit (version 5.4.0.8; IDBS, Munich, Germany) as reported by Krippendorff et al to give kinetic parameters. ${ }^{45}$

For the reversibility of thiol addition, a solution of $7 \mathbf{a}_{1}$ or $9 \mathbf{c}(200 \mu \mathrm{M})$ and $\beta$-Mercaptoethanol $(100 \mathrm{mM})$ in ammonium acetate buffer $(\mathrm{pH}=7.4)$ was incubated at $37^{\circ} \mathrm{C}$ for $24 \mathrm{~h}$. The reaction mixture was analyzed by LC-MS/MS. Then, it was diluted 10 -fold by addition of ammonium acetate buffer and incubated at $37^{\circ} \mathrm{C}$. After 24h, analysis of the solution was performed by LC-MS/MS.

FAK ELISA assay. U-87 MG cells were plated for each well in 24-well plates at $1 \times 10^{4}$ cells, incubated at $37^{\circ} \mathrm{C}, 5 \% \mathrm{CO}_{2}$ and treated with the inhibitors at different concentrations. After $48 \mathrm{~h}$, cell lysates were prepared and adjusted to the same concentrations with extraction buffer (10 mM Tris ( $\mathrm{pH} 7.4), 100 \mathrm{mM} \mathrm{NaCl}, 1 \mathrm{mM}$ EDTA, $1 \mathrm{mM}$ EGTA, $1 \mathrm{mM} \mathrm{NaF}, 20 \mathrm{mM} \mathrm{Na}_{4} \mathrm{P}_{2} \mathrm{O}_{7}, 2 \mathrm{mM} \mathrm{Na}_{3} \mathrm{VO}_{4}, 1 \%$ Triton $^{\mathrm{TM}}$ X-100, 10\% glycerol, 0.1\% SDS, and 0.5\% deoxycholate) with PMSF and protease inhibitor. According to manufacturer's instructions (Thermofisher Scientific, USA), 
cell lysates and detection antibody were added to each well except the chromogen blanks and incubated for $3 \mathrm{~h}$ at room temperature. After washing 4 times with $1 \mathrm{X}$ wash buffer, an anti-rabbit IgG HRP-conjugated solution was added except the chromogen blanks and incubated for $30 \mathrm{~min}$ at room temperature. Thoroughly aspirate the solution, wash wells 4 times with $1 \mathrm{X}$ wash buffer and add $100 \mu \mathrm{L}$ of stabilized Chromogen solution to each well and read OD at $450 \mathrm{~nm}$ using the microplate reader. The levels of FAK phosphorylation were normalized by the levels of total FAK protein.

Cell viability assay. Cell viability of glioblastomas cell lines (U-87 MG, A-172 and U-251) was evaluated by MTT assay. Brief, the cells were cultured in Dulbecco's Modified Eagle Medium (DMEM, 10567014, Gibco, USA) containing 10\% fetal bovine serum (FBS, Gibco, USA). 5000 cells were seeded for each well in 96-well culture plates and put in an incubator with $5 \% \mathrm{CO}_{2}$ at $37^{\circ} \mathrm{C}$ for 12 hours before the addition of $200 \mu \mathrm{L}$ of medium containing different concentrations of compounds. After incubation for 48 hours, the medium were replaced by $100 \mu \mathrm{L}$ of fresh DMEM containing 3-(4,5-dimethylthiazol-2-yl)-2,5-diphenyltetrazolium bromide (MTT, 0.5 $\mathrm{mg} / \mathrm{mL}$ at final concentration), and the cells were further incubated for 4 hours. The Optical density of each well was measured at $570 \mathrm{~nm}$ using a microplate reader. The data are expressed as the mean of three independent experiments. $\mathrm{IC}_{50}$ values were calculated using Graph-Pad Prism (GraphPad Software, San Diego, CA, USA).

Apoptosis determination. U-87 MG cells were seeded in 6-well culture plates at $2 \times 10^{s}$ cells. After $48 \mathrm{~h}$ incubation with the selected compounds, trypsinize the adherent 
cells from each well, wash the collected cells twice with PBS, centrifuge and re-suspend each pellet. The treated cells were collected and incubated in Annexin V binding buffer with Annexin V-FITC and propidium iodide for $30 \mathrm{~min}$ at room temperature. The cells were then washed, resuspended in Annexin V binding buffer, and analyzed by flow cytometry on a BD LSR II (Becton Dickinson, San Jose, CA). Results were analyzed using FlowJo software (Treestar, Ashland, OR).

Cell cycle analysis by flow cytometer. U-87 MG cells were plated for each well

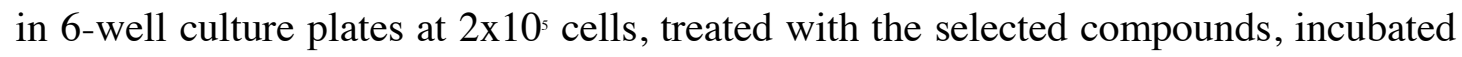
for $48 \mathrm{~h}$ and stained with $1 \mu \mathrm{g} / \mathrm{mL}$ propidium iodide. Cells were acquired by flow cytometer and cell cycle was analyzed using Dean-Jett-Fox methods on a FACS calibur (Becton Dickinson, San Jose, CA).

Scratch assay. U-87 MG cells were plated to confluence on six-well tissue culture dishes and a single scratch was made in the confluent monolayer using a sterile $10 \mu \mathrm{L}$ pipette tip. The monolayer was washed with PBS and added with medium containing either inhibitor $(0.2$ and $1 \mu \mathrm{M})$ or DMSO. Capturing the images during cell migration to close the scratch was taken at the beginning and after 24 and $48 \mathrm{~h}$.

Immunocytochemistry and confocal microscopy. U-87 MG cells were seeded at $2 \times 10^{s}$ cells on the coverslips. After $48 \mathrm{~h}$ incubation with the selected compounds, cells were fixed with $4 \%$ paraformaldehyde for 20 min and permeabilized with $0.2 \%$ Triton X-100 for $3 \mathrm{~min}$ at room temperature, then washed with PBS. The cells were incubated in blocking solution (PBS-Glycine 0.3 M-bovine serum albumin 1\%) for 
$1 \mathrm{~h}$ and then incubated with the primary antibody paxillin (Abcam Ab32084) in PBS for $1 \mathrm{~h} 30 \mathrm{~min}$ at room temperature. After washing with PBS-T (PBS containing $0.1 \%$ Tween-20), the cells were incubated with a second antibody conjugated with a fluorescent dye for $1 \mathrm{~h}$ at room temperature. For staining of actin and nucleus, FITC-conjugated phalloidin and TO-PRO-3 (Invitrogen) were included during the incubation with the secondary antibody. The coverslips were sealed with Dako Faramount Aqueous Mounting Medium Ready-to-use (Invitrogen) and images recorded using a Zeiss LSM 510 confocal microscope (Carl Zeiss Meditec France SAS, Le Pecq, France) using a 40 Plan-Neofluar 1.3 NA oil objective and LSM Image Browser (Zeiss).

Western Blotting Analysis. U-87 MG cells were seeded in six-well plates at $1 \times 10^{\text {s }}$ cells per well and cultured in the incubator for 24 hours before the culture medium was replaced by DMEM with $10 \%$ FBS containing $0,10.5,1,5$ and $10 \mu \mathrm{M}$ of compounds. The cells were incubated with different concentration of compounds for 48 hours. For washout experiments, PBS was used to wash the cells and then cultured for 3 hours with fresh culture medium.

Cells were collected, washed twice in ice-cold PBS and lysed for 20 min in 100 $\mu \mathrm{L}$ ice-cold cell lysis buffer (P0013B, Beyotime Biotechnology, China) containing 1 mM phenylmethanesulfonyl fluoride (ST506, Beyotime Biotechnology, China) and 2\% phosphatase inhibitor (P1081, Beyotime Biotechnology, China). Cell lysates from cytoplasm and nucleus were centrifuged at $12000 \mathrm{~g}$ for $10 \mathrm{~min}$ and the protein content was determined by BCA Protein Assay Kit (23225, Thermofisher Scientific, 
China). After adding load buffer and incubating in $95^{\circ} \mathrm{C}$ water bath for $7 \mathrm{~min}, 10 \mathrm{mg}$ of total protein of each sample was load to $8 \%$ polyacrylamide gels and transferred to PVDF membranes. The membranes were blocked with 5\% BSA in TBS/0.05\% Tween 20 (TBST) for 2 hours and incubated with the FAK (ab40794, Abcam), p-FAK (Tyr397) (ab81298, Abcam), Akt (4691, Cell Signaling Technology), p-Akt (Ser 473) (9271, Cell Signaling Technology), Erk1/2 (4695, Cell Signaling Technology), p-Erk1/2 (Thr202/Tyr204) (4377, Cell Signaling Technology), NF-xB (ab32536, Abcam), p-NF-xB (ab76032, Abcam) and $\beta$-actin (T0022, Affinity) primary antibodies over night. Blots were washed in TBST and incubated with Goat Anti-Rabbit IgG (H+L) HRP (S0001, Affinity) or Goat Anti-Mouse IgG (H+L) HRP (IH-0031, Beijing DingGuo ChangSheng Biotechnology) secondary antibody. Finally, the blots were washed in TBST and visualized with Immobilon Western Chemiluminescent HRP Substrate (WBKLS0100, Millipore) on the Chemiluminescence imaging system (P\&Q science and Technology, China).

\section{- ASSOCIATED CONTENT}

\section{Supporting Information}

The Supporting Information is available free of charge at

Kinetic mechanism for two-step covalent inhibition of FAK; molecular docking; intermediate synthesis; ions chromatograms obtained by QTRAP-MS; cell cycle 
distribution, HPLC purity of final compounds; 'H NMR and ${ }^{13} \mathrm{C}$ NMR spectra of final compounds (PDF)

Molecular string files for all of the final target compounds (CSV)

\section{- AUTHOR INFORMATION}

\section{Corresponding Author}

Huixiong Chen - Chemistry of RNA, nucleosides, peptides and heterocycles, CNRS UMR8601, Université de Paris, 45 rue des Saints-Pères, 75006 Paris, France; Tel: +33 1-428-640-85. Fax: +33 1-428-640-82. E-mail: huixiong.chen@ parisdescartes.fr.

\section{- ACKNOWLEDGMENTS}

We gratefully thank the support from la Ligue contre le cancer Paris Ile-de-France. BL thanks the China Scholarship Council (CSC) for financial support. YL thanks the support from National Natural Science Foundation of China (Grants 21672043). DL acknowledges support from Spanish Ministry of Economy, Industry and Competitiveness for the Retos Grant BFU2016-77665-R and the Ministry of Science, Innovation and Universities for the Spanish State Research Agency Retos Grant RTI2018-099318-B-I00, both cofunded by the European Regional Development Fund (FEDER).

\section{- ABBREVIATIONS USED}


GBM, glioblastoma; FAK, focal adhesion kinase; GSC, glioblastoma stem cell; ECM, epithelial mesenchymal transition; CSC, cancer stem cell; DIPEA, $N, N$-Diisopropylethylamine; $\quad \mathrm{PG}, \quad$ protecting group; $\quad$ EDCI, $N$-(3-Dimethylaminopropyl)- $N$ '-ethylcarbodiimide hydrochloride; HOBT, 1-Hydroxybenzotriazole hydrate; c-Src, Proto-oncogene tyrosine-protein kinase Src; FGFR1, Fibroblast growth factor receptor 1; IGF1R, insulin-like growth factor 1 receptor; PDGFR, Platelet-derived growth factor receptor; IR, insulin receptor; Akt, Protein kinase B; Erk, extracellular signal-regulated kinase; Pyk2, Proline-rich tyrosine kinase 2 .

\section{Notes}

The authors declare no competing financial interest.

\section{- REFERENCES}

(1) Clarke, J.; Butowski N.; Chang, S. Recent advances in therapy for glioblastoma. Arch Neurol. 2010, 67, 279-283.

(2) Grobben, B.; De Deyn, P. P.; Slegers, H. Rat C6 glioma as experimental model system for the study of glioblastoma growth and invasion. Cell Tissue Res. 2002, 310, $257-270$.

(3) Furnari, F. B.; Fenton, T.; Bachoo, R.M.; Mukasa, A.; Stommel, J. M.; Stegh, A.; Hahn, W. C.; Ligon, K. L.; Louis, D. N.; Brennan, C.; Chin, L.; DePinho, R. A.; 
Cavenee, W. K. Malignant astrocytic glioma: genetics, biology, and paths to treatment. Genes Dev. 2007, 21, 2683-2710.

(4) Ziegler, D. S.; Kung, A. L.; Kieran, M. W. Anti-apoptosis mechanisms inmalignant gliomas. J. Clin. Oncol. 2008, 26, 493-500.

(5) Garnier, D.; Renoult, O.; Alves-Guerra, M. C.; Paris, F.; Pecqueur, C. Glioblastoma stem-like cells, metabolic strategy to kill a challenging target. Front Oncol. 2019, 9, 118.

(6) Djedid, R.; Kiss, R.; Lefranc, F. Targeted therapy of glioblastomas: a 5 year view. Therapy, 2009, 6, 351-370.

(7) Stupp, R.; Mason, W. P.; Van Den Bent, M. J.; Weller, M.; Fisher, B.; Taphoorn, M. J.; Belanger, K.; Brandes, A. A.; Marosi, C.; Bogdahn, U.; Curschmann, J.; Janzer, R. C.; Ludwin, S. K.; Gorlia, T.; Allgeier, A.; Lacombe, D.; Cairncross, J. G.; Eisenhauer, E.; Mirimanoff, R. O. Radiotherapy plus concomitant and adjuvant temozolomide for glioblastoma. N. Engl. J. Med. 2005, 352, 987-996.

(8) Liu, T. J; LaFortune, T.; Honda, T.; Ohmori, O.; Hatakeyama, S.; Meyer, T.; Jackson, D.; de Groot, J.; Yung, W. K. Inhibition of both focal adhesion kinase and insulin-like growth factor-I receptor kinase suppresses glioma proliferation in vitro and in vivo. Mol Cancer Ther. 2007, 6, 1357-1367.

(9) Shi, Q.; Hjelmeland, A. B.; Keir, S. T.; Song, L.; Wickman, S.; Jackson, D.; Ohmori, O.; Bigner, D. D.; Friedman, H. S.; Rich, J. N. A novel low molecular weight 
inhibitor of focal adhesion kinase, TAE226, inhibits glioma growth. Mol. Carcinog. 2007, 46, 488-496.

(10) Yang, M.; Li, Y.; Chilukuri, K.; Brady, O. A.; Boulos, M. I.; Kappes, J. C.; Galileo, D. S. L1 stimulation of human glioma cell motility correlates with FAK activation. J Neurooncol. 2011, 105, 27-44.

(11) Cornillon, J.; Campos, L.; Guyotat, D. Focal adhesion kinase (FAK), une protéine aux fonctions multiples. Med.Sci. 2003, 19, 743-752.

(12) Zhang, J.; Hochwald; S. N. The role of FAK in tumor metabolism and therapy. Pharmacol. Ther. 2014, 142, 154-163.

(13) Cance, W. G.; Kurenova, E.; Marlowe, T.; Golubovskaya, V. Disrupting the scaffold to improve focal adhesion kinase-targeted cancer therapeutics. Sci. Signaling 2013, 6, pe10.

(14) Lechertier, T.; Hodivala-Dilke, K. Focal adhesion kinase and tumour angiogenesis. J. Pathol. 2012, 226, 404-412.

(15) Gutenberg, A.; Bruck, W.; Buchfelder, M.; Ludwig, H. C. Expression of tyrosine kinases FAK and Pyk2 in 331 human astrocytomas. Acta Neuropathol. 2004, $108,224-230$.

(16) Haskell, H.; Natarajan, M.; Hecker, T. P.; Ding, Q.; Stewart, Jr J.; Grammer, R.; Gladson, C. L. Focal adhesion kinase is expressed in the angiogenic blood vessels of 
malignant astrocytic tumors in vivo and promotes capillary tube formation of brain microvascular endothelial cells. Clin Cancer Res. 2003, 9, 2157-2165.

(17) Natarajan, M.; Hecker, T. P.; Gladson, C. L. FAK signaling in anaplastic astrocytoma and glioblastoma tumors. Cancer J. 2003, 9, 126-133.

(18) Yoon, H.; Dehart, J. P.; Murphy, J. M.; Lim, S. T. Understanding the roles of FAK in cancer: inhibitors, genetic models, and new insights. J. Histochem. Cytochem. 2015, 63, 114-128.

(19) Wu, Z. M.; Yan, X. H.; Jiang, P. C.; Li, Z. Q.; Wu, T. Antisense oligonucleotides targeting the focal adhesion kinase inhibit proliferation, induce apoptosis, and cooperate with cytotoxic drugs in human glioma cells. J Neurooncol. 2006, 77, 117-123.

(20) Lv, P. C.; Jiang, A. Q.; Zhang, W. M.; Zhu, H. L. FAK inhibitors in cancer, a patent review. Expert Opin. Ther. Pat. 2018, 28, 139-145.

(21) Shanthi, E.; Krishna, M. H.; Arunesh, G. M.; Venkateswara, R. K.; Sooriya, K. J.; Viswanadhan, V. N. Focal adhesion kinase inhibitors in the treatment of metastatic cancer: a patent review. Expert Opin. Ther. Pat. 2014, 24, 1077-1100.

(22) Shi, Q.; Hjelmeland, A. B.; Keir, S. T.; Song, L.; Wickman, S.; Jackson, D.; Ohmori, O.; Bigner, D. D.; Friedman, H. S.; Rich, J. N. A novel low-molecular weight inhibitor of focal adhesion kinase, TAE226, inhibits glioma growth. Mol. Carcinog. 2007, 46, 488-496. 
(23) Liu, T. J.; LaFortune, T.; Honda, T.; Ohmori, O.; Hatakeyama, S.; Meyer, T.; Jackson, D., de Groot, J., Yung, W. K. Inhibition of both focal adhesion kinase and insulin-like growth factor-I receptor kinase suppresses glioma proliferation in vitro and in vivo. Mol. Cancer Ther. 2007, 6, 1357-1367.

(24) Lonsdale, R.; Ward, R. A. Structure-based design of targeted covalent inhibitors. Chem. Soc. Rev. 2018, 47, 3816-3830.

(25) Barf, T.; Kaptein, A. Irreversible protein kinase inhibitors: balancing the benefits and risks. J. Med. Chem. 2012, 55, 6243-6262.

(26) Tan, L.; Wang, J.; Tanizaki, J.; Huang, Z.; Aref, A. R.; Rusan, M.; Zhu, S. J.; Zhang, Y.; Ercan, D.; Liao, R. G.; Capelletti, M.; Zhou, W.; Hur, W.; Kim, N.; Sim, T.; Gaudet, S.; Barbie, D. A.; Yeh, J. R. J.; Yun, C. H.; Hammerman, P. S.; Mohammadi, M.; Jänne, P. A.; Gray, N. S. Development of covalent inhibitors that can overcome resistance to first-generation FGFR kinase inhibitors. Proc. Natl. Acad. Sci. U S A. 2014, 111, E4869-E4877.

(27) Yen-Pon, E. Li, B.; Acebrón-Garcia-de-Eulate, M.; Tomkiewicz-Raulet, C.; Dawson, J.; Lietha, D.; Frame, M. C.; Coumoul, X.; Garbay, C.; Etheve-Quelquejeu, M.; Chen, H. Structure-based design, synthesis, and characterization of the first irreversible inhibitor of focal adhesion kinase. ACS Chem. Biol. 2018, 13, 2067-2073.

(28) Roberts, W. G.; Ung, E.; Whalen, P.; Cooper, B.; Hulford, C.; Autry, C.; Richter, D.; Emerson, E.; Lin, J.; Kath, J.; Coleman, K.; Yao, L.; Martinez-Alsina, L.; Lorenzen, M.; Berliner, M.; Luzzio, M.; Patel, N.; Schmitt, E.; LaGreca, S.; Jani, J.; 
Wessel, M.; Marr, E.; Griffor, M.; Vajdos, F. Antitumor activity and pharmacology of a selective focal adhesion kinase inhibitor, PF 562,271. Cancer Res. 2008, 68, $1935-1944$.

(29) Serafimova, I. M.; Pufall, M. A.; Krishnan, S.; Duda, K.; Cohen, M. S.; Maglathlin, R. L.; McFarland, J. M.; Miller, R. M.; Frödin, M.; Taunton, J. Reversible targeting of noncatalytic cysteines with chemically tuned electrophiles. Nat. Chem. Biol. 2012, 8, 471-476.

(30) Schüttelkopf, A. W.; van Aalten, D. M. F. PRODRG: a tool for high-throughput crystallography of protein-ligand complexes, Acta Crystallogr. 2004, D60, 1355-1363.

(31) Lebedev, A. A.; Young, P.; Isupov, M. N.; Moroz, O. V.; Vagin, A. A.; Murshudov, G. N. JLigand: a graphical tool for the CCP4 template-restraint library. Acta Crystallogr. D Biol. Crystallogr. 2012, 68, 431-440.

(32) Richter, D. T.; Kath, J. C.; Luzzio, M. J.; Keene, N.; Berliner, M. A.; Wessel, M. D. Selective addition of amines to 5-trifluoromethyl-2,4-dichloropyrimidine induced by Lewis acids. Tetrahedron Lett. 2013, 54, 4610-4612.

(33) Pritchard, R. B.; Lough, C. E.; Currie, D. J.; Holmes, H. L. Equilibrium reactions of N-butanethiol with some conjugated heteroenoid compounds. Can. J. Chem. 1968, 46, 775-781. 
(34) Flippot, R.; Kone, M.; Magné, N.; Vignot, S. FGF/FGFR Signalling: implication in oncogenesis and perspectives. Bull Cancer, 2015, 102, 516-526.

(35) Chagoya, G.; Kwatra, S. G.; Nanni, C. W.; Roberts, C. M.; Phillips, S. M.; Nullmeyergh, S.; Gilmore, S. P.; Spasojevic, I.; Corcoran, D. L.; Young, C. C.; Ballman, K. V.; Ramakrishna, R.; Cross, D. A.; Markert, J. M.; Lim, M.; Gilbert, M. R.; Lesser, G. J.; Kwatra, M. M. Efficacy of osimertinib against EGFRvIII+ glioblastoma. Oncotarget. 2020, 11, 2074-2082.

(36) Ma, Y.; Tang, N.; Thompson, R. C.; Mobley, B. C.; Clark, S. W.; Sarkaria, J. N.; Wang, J. InsR/IGF1R pathway mediates resistance to EGFR inhibitors in glioblastoma. Clin Cancer Res. 2016, 22, 1767-1776.

(37) Kurio, N.; Shimo, T.; Fukazawa, T.; Takaoka, M.; Okui, T.; Hassan, N. M. M.; Honami, T.; Hatakeyama, S.; Ikeda, M.; Naomoto, Y.; Sasaki, A. Anti-tumor effect in human breast cancer by TAE226, a dual inhibitor for FAK and IGF-IR in vitro and in vivo. Exp Cell Res. 2011, 317, 1134-1146.

(38) Dao, P.; Smith, N.; Tomkiewicz-Raule, C.; Yen-Pon, E.; Camacho-Artacho, M.; Lietha, D.; Herbeuval, J. P.; Coumoul, X.; Garbay, C.; Chen, H. Design, Synthesis, and evaluation of novel imidazo[1,2-a][1,3,5]triazines and their derivatives as focal adhesion kinase inhibitors with antitumor activity. J. Med. Chem. 2015, 58, 237-251.

(39) He, X.; Chen, X.; Li, B.; Ji, J.; Chen, S. FAK inhibitors induce cell multinucleation and dramatically increase pro-tumoral cytokine expression in RAW 264.7 macrophages. FEBS Lett. 2017, 591, 3861-3871. 
(40) Pollard, T. D.; Cooper, J. A. Actin, a central player in cell shape and movement. Science. 2009, 326, 1208-1212.

(41) Tojkander, S.; Gateva, G.; Lappalainen, P. Actin stress fibers-assembly, dynamics and biological roles. J Cell Sci. 2012, 125, 1855-1864.

(42) Shannon, S.; Jia, D.; Entersz, I.; Beelen, P.; Yu, M.; Carcione, C.; Carcione, J.; Mahtabfar, A.; Vaca, C.; Weaver, M.; Shreiber, D.; Zahn, J. D.; Liu, L.; Lin, H.; Foty, R. A. Inhibition of glioblastoma dispersal by the MEK inhibitor PD0325901, BMC Cancer 2017, 17, 121.

(43) Wang, H.; Wang, H.; Zhang, W.; Huang, H. J.; Liao, W. S.; Fuller, G. N. Analysis of the activation status of Akt, NFkappaB, and Stat3 in human diffuse gliomas. Lab Invest. 2004, 84, 941-951.

(44) Sudheerkumar, P.; Shiras, A.; Das, G.; Jagtap, J. C.; Prasad, V.; Shastry, P. Independent activation of Akt and NF-kappaB pathways and their role in resistance to TNF-alpha mediated cytotoxicity in gliomas. Mol Carcinog. 2008, 47, 126-136.

(45) Krippendorff, B. F.; Neuhaus, R.; Lienau, P.; Reichel, A.; Huisinga, W. J. Mechanism-based inhibition: deriving KI and kinact directly from time-dependent IC50 values. Biomol. Screen 2009, 14, 913-919. 